\title{
EFFECTIVENESS OF DECANTER MODIFICATIONS ON ORGANIC REMOVAL (U)
}

\author{
WSRC-RP-- $92-996$
}

by D.P. Lambert

DE93 006167

Westinghouse Savannah River Company

Savannah River Site

Aiken, South Carolina 29808

Other Authors:

This paper was prepared in connection with work done under Contract No. DE-AC09-89SR18035 with the U. S. Department of Energy. By acceptance of this paper, the publisher and/or recipient acknowledges the U. S. Government's right to retain a nonexclusive, royalty-free license in and to any copyright covering this paper, along with the right to reproduce and to authorize others to reproduce all or part of the copyrighted paper. 


\section{DISCLAIMER}

This report was prepared as an account of work sponsored by an agency of the United States Government. Neither the United States Government nor any agency thereof, nor any of their employees, makes any warranty, express or implied, or assumes any legal liability or responsibility for the accuracy, completeness, or usefulness of any information, apparatus, product, or process disclosed, or represents that its use would not infringe privately owned rights. Reference herein to any specific commercial product, process, or service by trade name, trademark, manufacturer, or otherwise does not necessarily constitute or imply its endorsement, recommendation, or favoring by the United States Government or any agency thereof. The views and opinions of authors expressed herein do not necessarily state or reflect those of the United States Government or any agency thereof.

This report has been reproduced directly from the best available copy.

Available to DOE and DOE contractors from the Office of Scientific and Technical Information, P.O. Box 62, Oak Ridge, TN 37831; prices available from (615) 576-8401, FTS 626-8401.

Available to the public from the National Technical Information Service, U.S. Department of Commerce, 5285 Port Royal Rd, Springfield, VA 22161. 
CC: R. T. Begley, 773-A

L. M. Papouchado, 773-A

E. W Holtzscheiter,773-A

E. F. Duhn, 773-A

M. J. Plodinec, 773-A

N. E. Bibler, 773-A

L. F. Landon, 704-T

C. T. Randall, 704-T

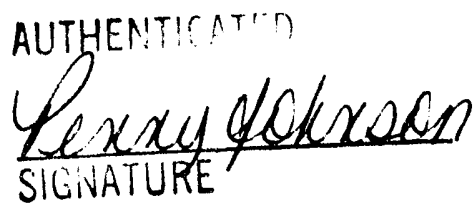

PTD Group (8)

LSE Group (7)

Glass Technology Group

SRTC Records (4)

August 20, 1992

TO:

J. T. CARTER, 704-1T

FROM :

D. P. LAMBERT, 704-1T Dan fault

\section{Effectiveness of Decanter Modifications on Organic Removal}

\section{INTRODUCTION}

A series of runs were planned in the Precipitate Hydrolysis Experimental Facility (PHEF) to determine the effectiveness of equipment and process modifications on the PHEF decanter organic removal efficiency. Runs 54-59 were planned to test the effectiveness of spray recirculation, a new decanter, heated organic recirculation and aqueous drawoff on organic removal efficiency in the revised HAN flowsheet. Runs 60-63 were planned to provide a comparison of the original and new decanter designs on organic removal efficiency in the late wash flowsheet without organic recirculation.

Operational problems were experienced in both the PHEF and IDMS pilot facilities because of the production of high boiling organics and the low organic removal efficiency of the PHEF decanters. To prevent these problems in the DWPF Salt and Chemical Cells, modifications were proposed to the decanter and flowsheet to maximize the organic removal efficiency and minimize production of high boiling organics.

\section{SUMMARY}

The new decanter design is more efficient in the HAN process at replacing decanter high boiling organics with fresh benzene than the original decanter design. The extraction efficiency of both decanters is basically equal so the new decanter should have improved long term performance, especially in the HAN flowsheet. Organic liquid recirculation or organic vapor cleaning will be necessary to maintain high decanter efficiency in the HAN process.

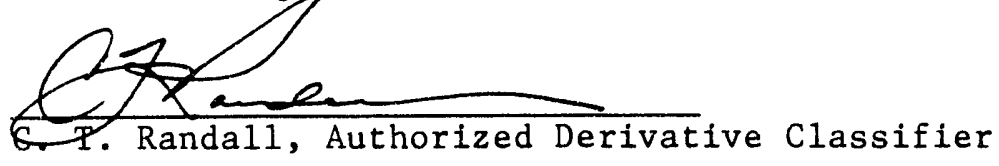


The new decanter design is also more efficient in the late wash pr:"ess at replacing decanter high boiling organics with fresh be. sne than the original decanter design. The extraction efficiency of the new decanter is higher in the late wash flowsheet.

Organic vapor recirculation is an effective method of cleaning organic deposits from condenser tubes and replacing the RCD organic with virtually pure benzene. Extraction efficiency in the decanter is improved because the lower high boiling organic concentration leads to a higher driving force for extraction. A jumper could be used to route $O E$ vapors from the $O E$ to the RCD to accomplish this cleaning. Further study is needed to determine the frequency that this cleaning is needed. This will be included in the next PHEF Task Plan which is being drafted.

The highest quality PHA is produced in runs where the lowest concentration of diphenylamine is produced, maximum steam stripping of high boiling organics is accomplished, and maximum decanter extraction efficiency is attained. The late wash flowsheet, with minimal nitrite present in the feed, produces the lowest quantities of diphenylamine. The late wash flowsheet also produces a higher ratio of benzene to high boiling organics which will provide a larger volume of benzene for extracting the high boiling organics. A number of methods are available to increase the amount of stripping including lengthening the aqueous boil cycle, increasing the boilup rate during aqueous boil, or increasing the feed and hold temperature. A cycle time study should be performed on the salt cell to determine if any of these options would be useful for improving the quality of the PHA product.

This report also functions as a summary of the Runs 54-59 decanter studies. Appendixes $B$ and $C$ contain run summary information and the process control sample analyses.

\section{BECOMMENDATIONS}

1. Modify the decanter design, to incorporate the changes as specified in WSRC-RP-91-1134, "Preliminary Salt Cell Decanter Design Modifications", November 1991.

2) Organic liquid recirculation from the $O E$ to the $R C D$ should be used in the HAN process, but not with the late wash flowsheet.

3) Complete a salt cell time study to determine the optimum operational schedule to maximize stripping (which will minimize the high boiling concentration in the PHA).

4) Minimize the concentration of nitrite in the precipitate slurry to minimize the diphenylamine production. 


\section{RESUITS}

The results of the decanter testing are discussed in detail in the following two sections on decanter performance in the (1) HAN process (section A) and (2) late wash process (section B). Other factors which contribute to PHA product quality are discussed in section $C$. A discussion of the decanter design, decanter problems, and overall performance is summarized in section $D$.

Section

A. DECANTER PERFORMANCE IN THE REVISED HAN PROCESS

B. DECANTER PERFORMANCE WITH LATE WASH FLOWSHEET

C. OTHER CONSIDERATIONS FOR IMPROVING PHA QUALITY

D. DECANTER DISCUSSION

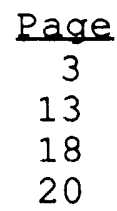

A. DECANTER REREORMANCE IN THE REVISED HAN PROCESS

The revised HAN process (2:1 ratio of HAN to nitrite) was developed to minimize the production of high boiling organics at the design nitrite concentration of $0.18-0.20 \mathrm{M}$. The production of diphenylamine in the revised HAN process is much higher than in the late wash process $(<0.01 \mathrm{M})$ because of the higher nitrite concentration in the HAN slurry. The production of biphenyl and terphenyls is similar in the revised HAN and late wash flowsheets because their production is related to free radical production which is expected to be similar in both processes.

Runs 54-59 were studies of the effectiveness of a number of process and equipment modifications in attempts to improve decanter performance. A summary of runs $54-59$ is listed in Appendix $B$ and runs 54-59 analytical data is listed in Appendix $\mathrm{C}$

\section{A.1 OVERALL DECANTER EFFECTIVENESS IN HAN PROCESS}

The long term effectiveness of the original decanter in the HAN process will be poor because of the high production of high boiling organics. The use of the new decanter is necessary because it is much better at self-cleaning than the original decanter. A number of operational changes can be made to improve the PHA quality, but the PHA will have a high concentration of high boiling organics which will cause operational problems in the salt and Chemical Processing Cells.

The new decanter design is the only test which was successful in improving long term decanter extraction efficiency by replacing the high boiling organics in the decanter with fresh benzene generated during feed and organic boil. A higher boilup rate during aqueous boil would increase stripping and the new coalescer would improve biphenyl 
extraction but further testing is necessary to determine if they would improve long term PHA quality. A summary of the HAN flowsheet decanter studies is listed in Table 4:

Table 4

Summary of Decanter Testing with HAN flowsheet

\begin{tabular}{|l|l|l|l|l|}
\hline $\begin{array}{l}\text { PHEF } \\
\text { Run(s) }\end{array}$ & Description & Decanter & Effectiveness & $\begin{array}{l}\text { DWPF } \\
\text { Usefulness }\end{array}$ \\
\hline $56-59$ & New Decanter & New & Good & Good \\
\hline 54,55 & Spray Nozzles & Original & Poor & None \\
\hline 54,55 & $\begin{array}{l}\text { Aqueous } \\
\text { Drawoff }\end{array}$ & Original & Marginal & None \\
\hline 56 & $\begin{array}{l}\text { Aqueous } \\
\text { Drawoff }\end{array}$ & New & Marginal & None \\
\hline $57,58,59$ & $\begin{array}{l}\text { Heated Organic } \\
\text { Recirculation }\end{array}$ & New & Marginal & None \\
\hline $57,58,59$ & $\begin{array}{l}\text { Lower Boilup } \\
\text { Rate }\end{array}$ & New & Marginal & None \\
\hline 59 & Coalescer & New & Good & $\begin{array}{l}\text { Needs more } \\
\text { testing }\end{array}$ \\
\hline 57 & $\begin{array}{l}\text { Higher Boilup } \\
\text { Rate }\end{array}$ & New & Good & $\begin{array}{l}\text { Needs more } \\
\text { testing }\end{array}$ \\
\hline
\end{tabular}

\section{A.2 NEW DECANTER}

A new decanter was installed prior to Run 56 to improve decanter performance. The new decanter design replaced the baffle and downcomer section of the decanter with an open decanter and replaced the organic overflow weir with an organic underflow arrangement. The design basis for the decanter was to develop a vessel that would 1) force heavy organics out of the decanter near the organic/aqueous interface, and 2) remove the downcomer section of the decanter. This would allow the fresh benzene produced during the feed and organic boil sections of the run to replace the heavy organics that had accumulated in the decanter during the previous run's steam stripping. Eliminating the downcomer was expected to lower the entrainment of organics in the aqueous during stripping.

The best test of the effectiveness of the new design on "flushing" the high boiling organics from the decanter is to determine how the concentration in the decanter changes during the run. Samples are pulled from the organic section of the decanter and a comparison of the high boiling organic concentrations from original and new decanters. For comparison purposes, runs 54 and 55 will be compared to runs 56 and 57. A summary of high boiling organic concentrations is summarized in Tables 8 and 9.

The new decanter is much more efficient in replacing the decanter organics with fresh benzene during organic boil than 
the oriqinal decanter based on the decanter concentrations before the reaction and after organic boil. The biphenyl and diphenylamine concentration dropped during runs 56 and 57 although only the biphenyl concentration dropped during run 54. The average biphenyl concentration drop during feed and aqueous boil was $46 \%$ and the average diphenylamine concentration drop during feed and aqueous boil was $67 \%$. The ability of the new decanter to remove high concentrations of high boiling organics from the decanter will help prevent the buildup of the high concentrations seen in the original decanter.

Table 8

Decanter Biphenyl Concentration During Feed and Organic Boil

\begin{tabular}{|l|l|c|l|}
\hline Run & $\begin{array}{l}\text { RCD Organic } \\
\text { Pre-Rxn } \\
m g / L\end{array}$ & $\begin{array}{l}\text { RCD Organic } \\
\text { Post-Organic } \\
\text { Boil, mg/L }\end{array}$ & \% change \\
\hline 54 (old) & 92,037 & 83,274 & $-9.52 \%$ \\
\hline 55 (old) & 57,400 & 70,841 & $23.42 \%$ \\
\hline 56 (new) & 69,553 & 44,793 & $-35.60 \%$ \\
\hline 57 (new) & 114,879 & 49,281 & $-57.10 \%$ \\
\hline
\end{tabular}

Table 9

Decanter Diphenylamine Concentration During Feed and Organic Boil

\begin{tabular}{|l|c|c|c|}
\hline Run & $\begin{array}{l}\text { RCD Organic } \\
\text { Pre-Rxn } \\
\text { mg/L }\end{array}$ & $\begin{array}{l}\text { RCD Organic } \\
\text { Post-Organic } \\
\text { Boil, mg/L }\end{array}$ & \% change \\
\hline 54 (old) & 31,874 & 35,764 & $12.20 \%$ \\
\hline 55 (old) & 2,454 & 10,373 & $322.70 \%$ \\
\hline 56 (new) & 3,628 & 1,748 & $-51.82 \%$ \\
\hline 57 (new) & 23,161 & 3,833 & $-83.45 \%$ \\
\hline
\end{tabular}

A test of the effectiveness of the decanter in minimizing entrainment is to monitor the concentration of the aqueous returning from the decanter to the PR. The lower the concentration of high boiling organics in the decanter aqueous return, the better the decanter extraction efficiency. For comparison purposes, run 51 will be compared to run 56 (the spray nozzle experiment makes use of Run 54 and 55 aqueous boil data unusable). A summary of the aqueous return high boiling organic concentration is summarized in Figure 51/56-2.

The new decanter is approximately equal to the original decanter in extracting the high boiling organics from the aqueous. There was more data gathered during Run 56 but the data collected every 60 minutes agrees very well. Both runs had comparable organic concentrations in the decanter at the beginning of the run. 
FIGURE 51/56-2

COMPARISON OF RUN 51 TO 56 AQUEOUS RETURN SAMPLES OLD DECANTER PERFORMANCE VS NEW DECANTER

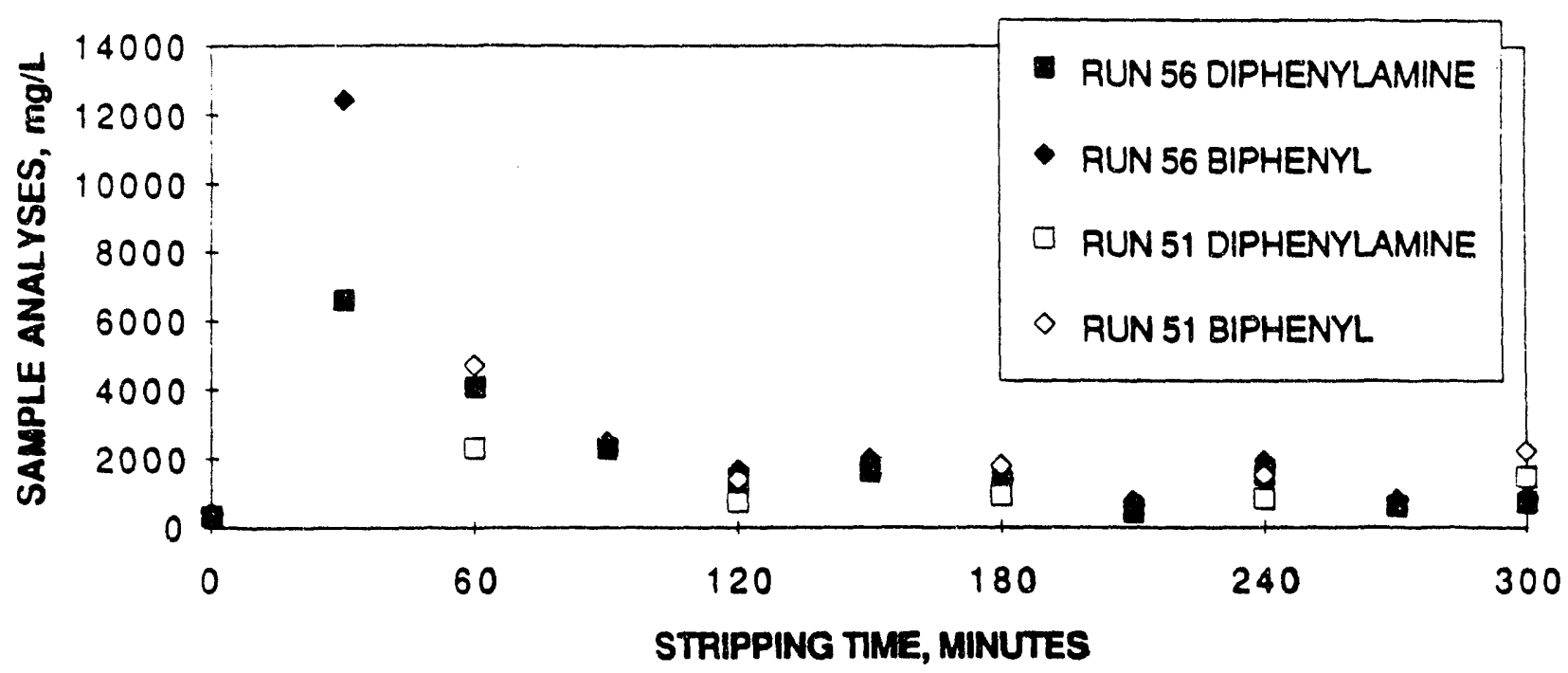

\section{A.3 SPRAY NOZZLES}

Organic liquid recirculation through spray nozzles was used in Runs 54 and 55 to determine whether the improved mixing between the organic and aqueous would improve existing decanter performance. The organic liquid was pumped from the $O E$ to the RCD at a rate of $1 \mathrm{gpm}$ and sprayed on the baffle above the decanter organic. The rationale for introducing a spray into the condenser is that the mixing of the organic and aqueous phases in the decanter would allow a better extraction of high boiling organics from the aqueous condensate.

The spray nozzles were ineffective in improving extraction efficiency. The PR diphenylamine concentration was higher at the end of stripping during both run 54 and 55 than at the beginning of stripping. As can be seen from the graphs of PR concentrations (Figures 54-1 and 55-1) during stripping, the diphenylamine concentration went up throughout the first 300 minutes of stripping. The biphenyl concentration went up during the first 90 minutes of stripping and decreased as expected during the next 210 minutes. 


\section{FIGURE 54-1}

RUN 54 PR SAMPLES

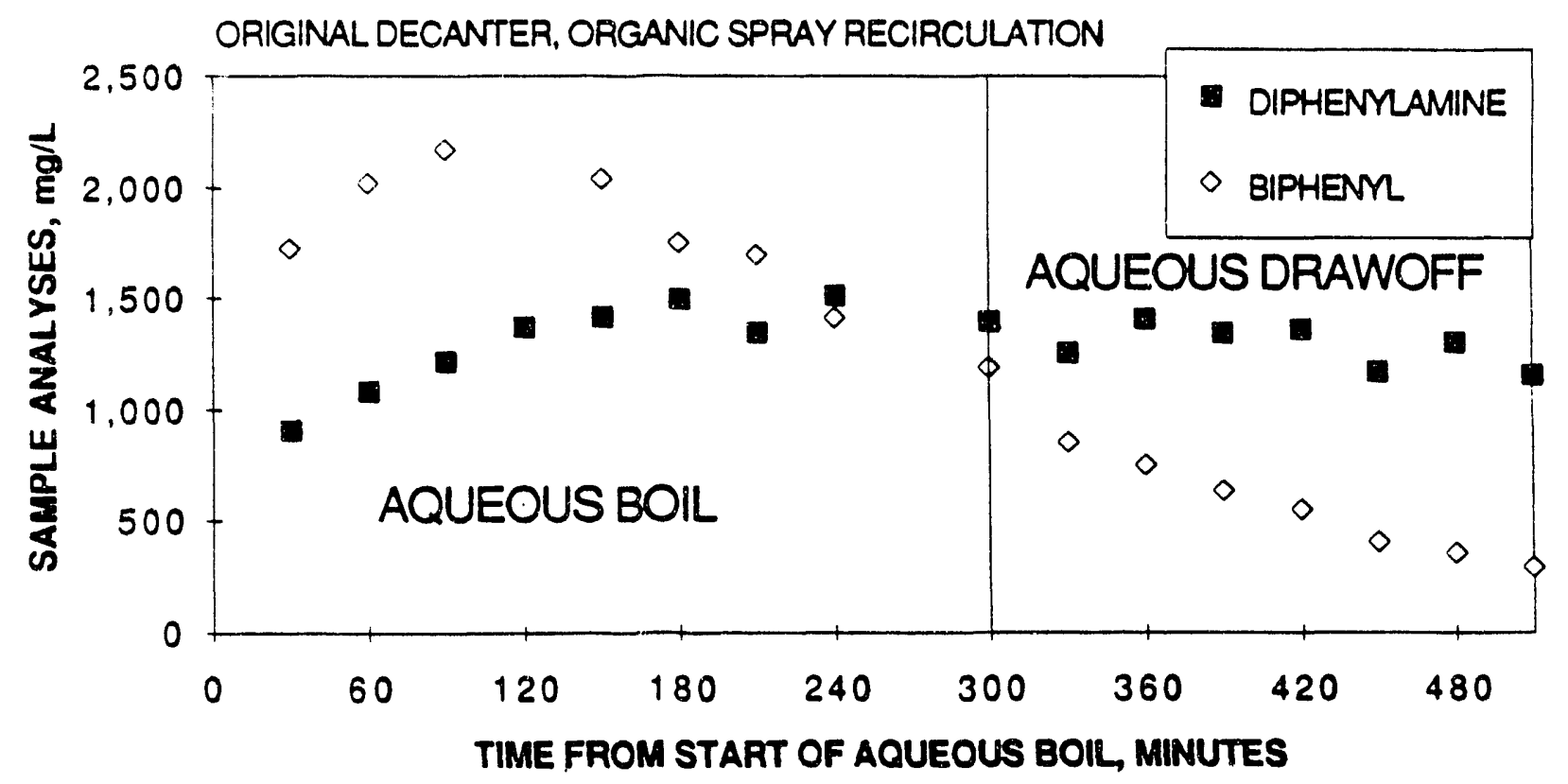

FIGURE 55-1

RUN 55 PR SAMPLES

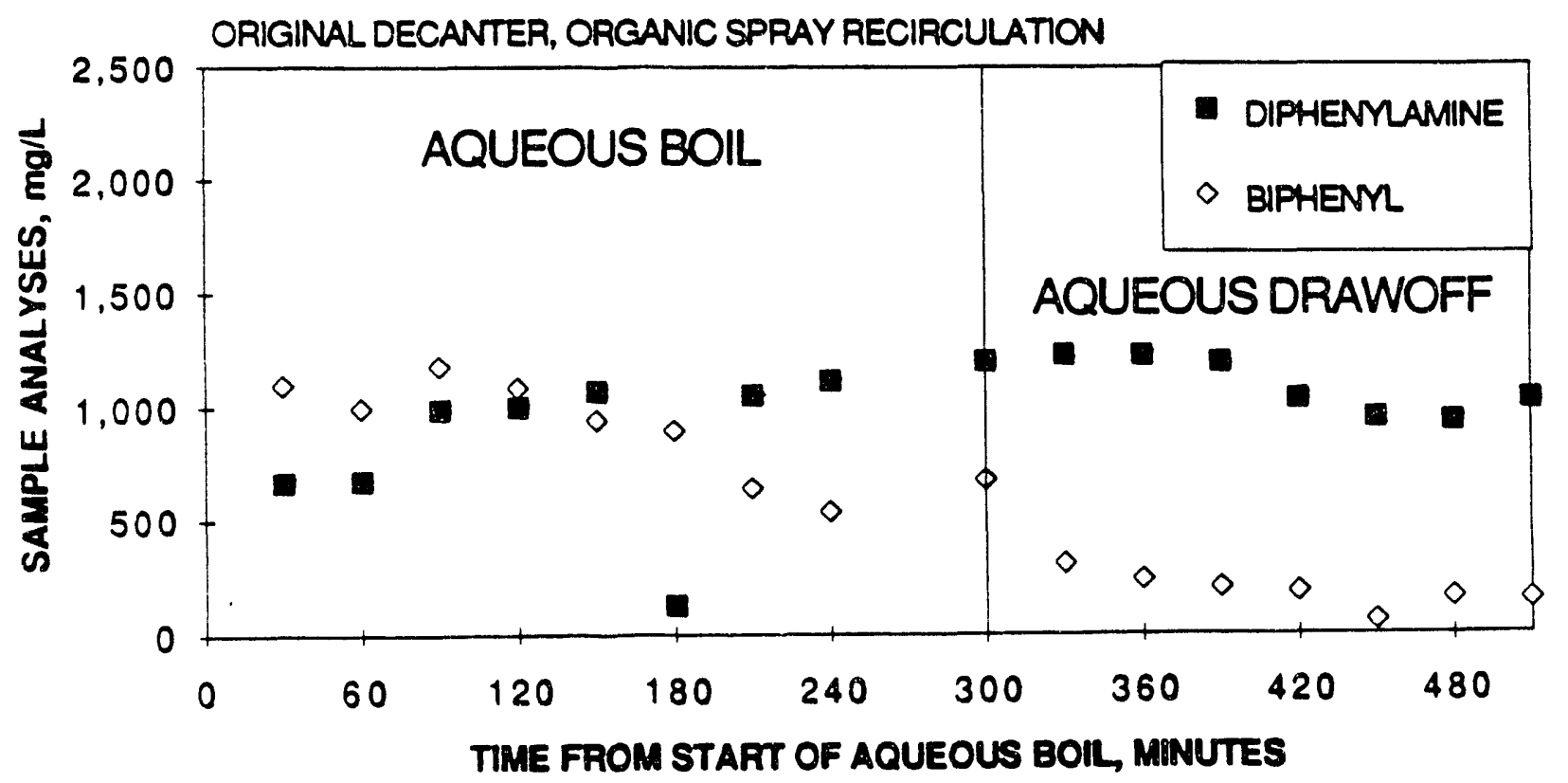


J. T. CARTER PAGE 8 WSRC-RP-92-996

The unusual increase in high boiling organic concentration at the beginning of stripping is believed to be caused by excessive high boiling organic entrainment in the decanter aqueous returned to the PR. It is likely that the organic spray on the decanter wall and downcomer may have been cleaned any buildup of high boiling organics. The spray may have also caused entrainment of organic in the aqueous causing the poor extraction performance.

An inspection after the Run 55 showed no organic deposits inside the decanter. Production of diphenylamine and biphenyl are not expected at this time in the run since hydrolysis is virtually complete. Figures 54-2 and 55-2 show the aqueous return concentrations during these runs.

\section{FIGURE 54-2}

RUN 54 AQUEOUS RETURN SAMPLES

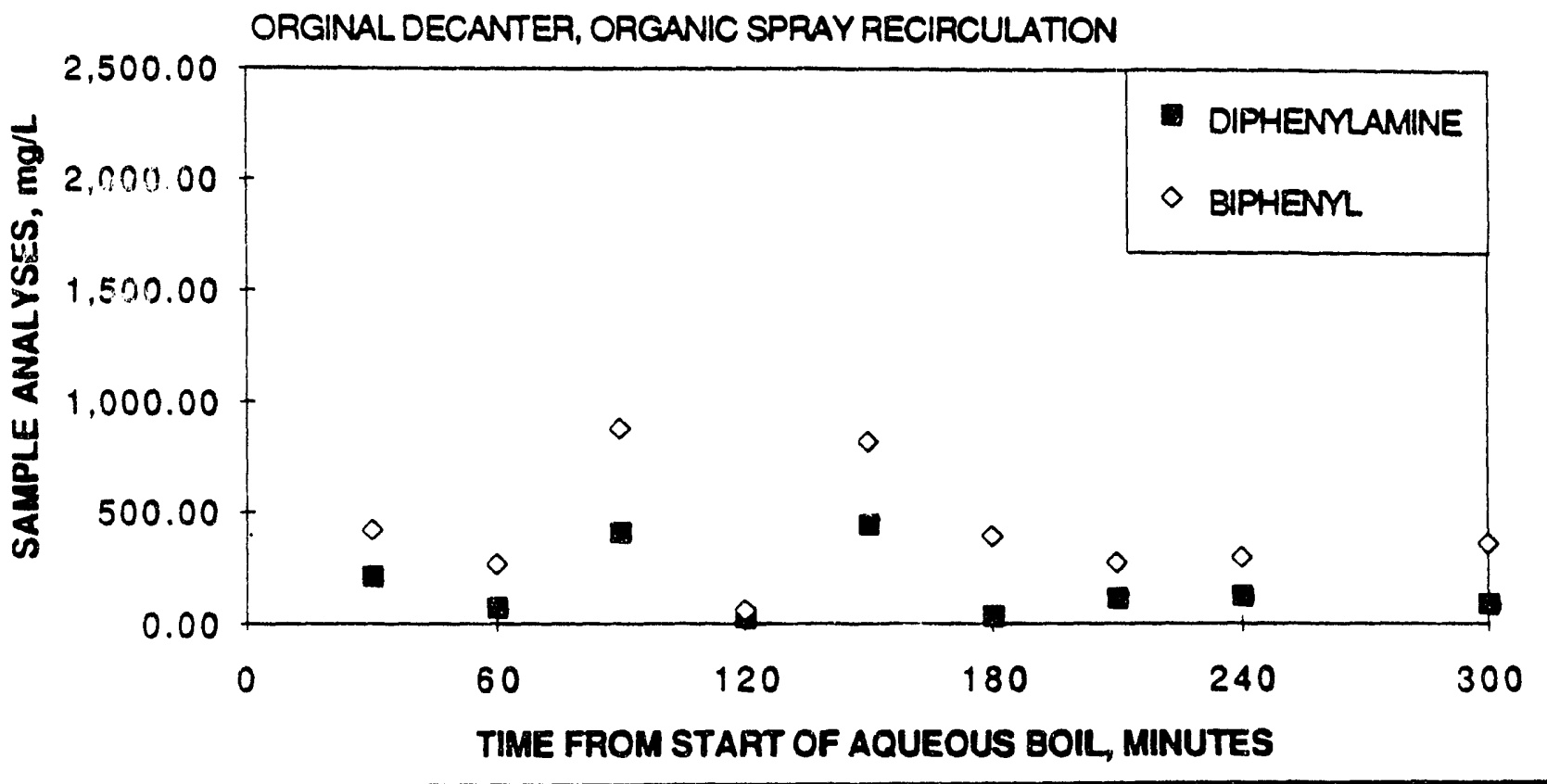


FIGURE 55-2

RUN 55 AQUEOUS RETURN SAMPLES

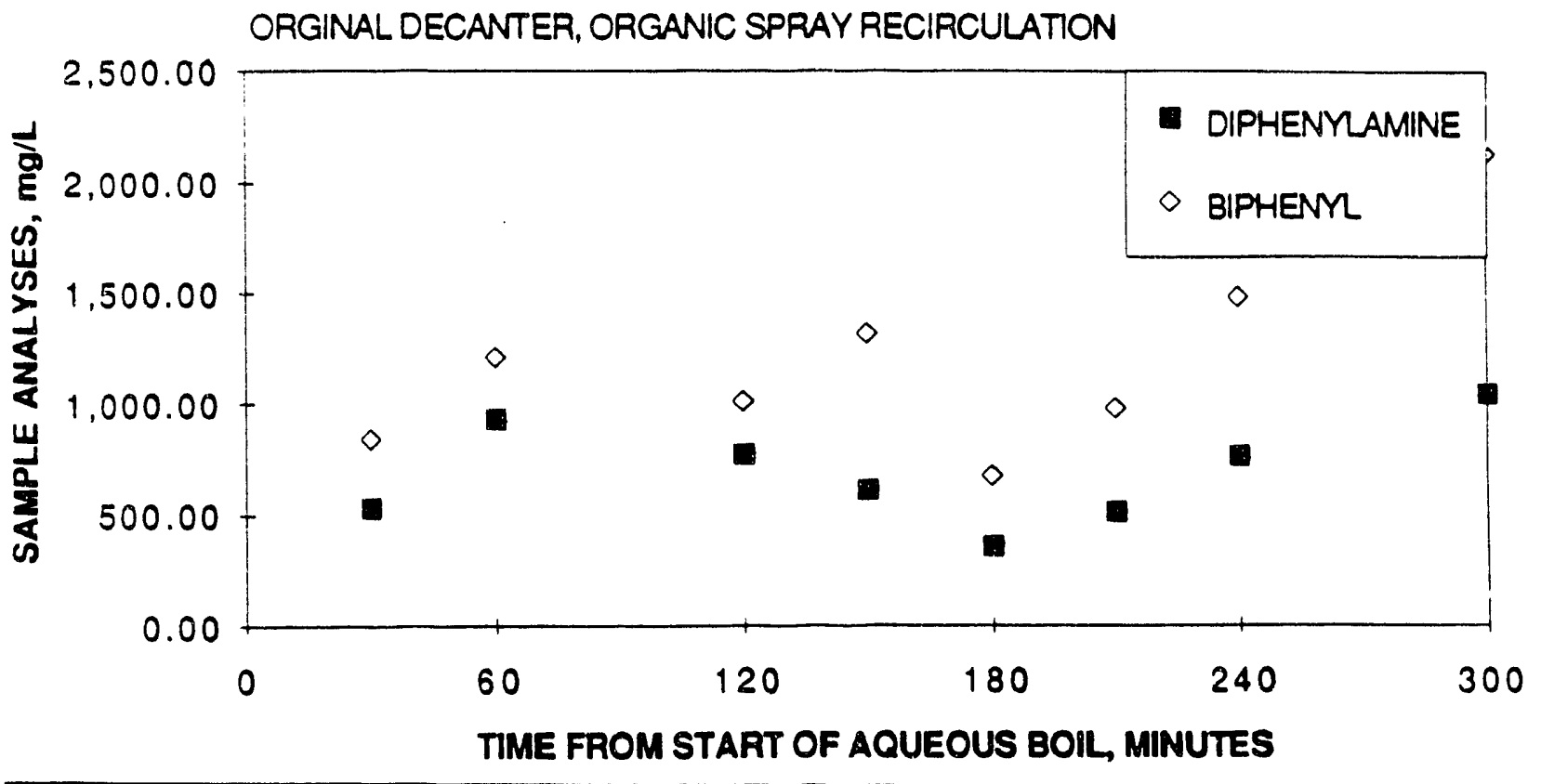

\section{A.4 AQUEOUS DRAWOFF}

Aqueous drawoff was tested in PHEF runs 54, 55, and 56 in an attempt to decrease the high boiling organic content in the PHA. After five hours of stripping, the aqueous return was redirected from the $P R$ to the $O E$ by closing the aqueous return valve. Both aqueous and organic are transferred from the RCD to the OE. It should be noted that aqueous drawoff empties the decanter of organic, so it must be "reinventoried" with organic before the next run. The boilup rate was maintained at $400 \mathrm{lb} / \mathrm{hr}$ for approximately 210 minutes, the maximum time that the OE could accept condensate from the decanter.

The apparent effectiveness of aqueous drawoff was marginal. In runs with poor decanter extraction efficiency (runs 54 and 55), the net removal of biphenyl and diphenylamine from the decanter is higher during aqueous drawoff than during normal aqueous boil. In runs with better decanter extraction efficiency, aqueous drawoff produces a higher concentration of high boiling organics in the PR than would be seen with the same time of aqueous boil.

Aqueous drawoff stripping efficiency should be independent of which decanter is installed, since no liquid is returned to the PR. However, the data showed a significant difference between the stripping rates in the old and new decanters. The half lives during stripping are summarized in Table 5. 
Table 5

\begin{tabular}{|l|c|c|}
\hline \multicolumn{2}{|c|}{ Calculated } & Biphenyl Strifping Half Lives \\
\hline & $\begin{array}{l}\text { Aqueous Boil } \\
\text { Biphenyl Stripping } \\
\text { Half Life, min }\end{array}$ & $\begin{array}{l}\text { Aqueous Drawoff } \\
\text { Biphenyl Stripping } \\
\text { Half Life, min }\end{array}$ \\
\hline $\begin{array}{l}54 \text { (Old Decanter, Spray } \\
\text { Nozzles) }\end{array}$ & 195 & 107 \\
\hline $\begin{array}{l}55 \text { (Old Decanter, Spray } \\
\text { Nozzles) }\end{array}$ & 198 & 186 \\
\hline 56 (New Decanter) & 118 & 250 \\
\hline
\end{tabular}

The diphenylamine vapor concentration is approximately equal to its liquid concentration at $100^{\circ} \mathrm{C}$, so there is a minimal decrease in diphenylamine concentration during aqueous drawoff (Figures 54-1, 55-1, 56-1).

\section{FIGURE 56-1 \\ RUN 56 PR SAMPLES}

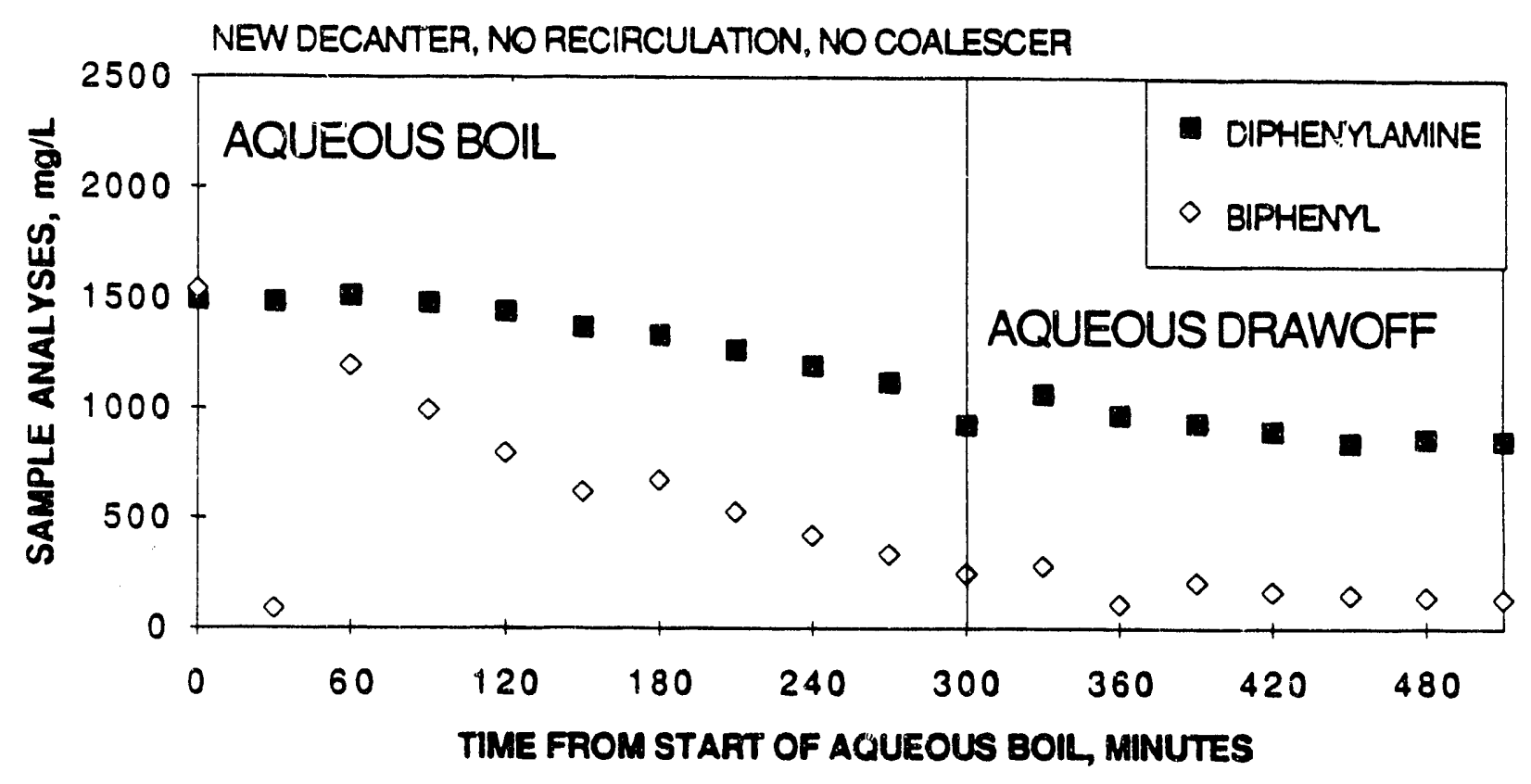

The major advantage of aqueous drawoff is it will decrease the high boiling organic mass in the PHA by transferring any organic or aqueous boiled up from the PR to the OE. As a result, aqueous drawoff would be most effective in runs where decanter extraction efficiency is lowest. Aqueous drawoff has the potential to remove greater than $20 \%$ of the high boiling organic mass from the PHA. However, it will add 3.5 
hours to the cycle time and require the addition of a valve in the aqueous return line in DWPF. Attempts to improve extraction efficiency would be better alternatives to aqueous drawoff.

\section{A.5 HEATED ORGANIC IIQUID WITH RECIRCULATION}

A test was condur ed during runs 58 and 59 to determine whether heating lue organic in the decanter would increase the high boiling solubility sufficiently to improve decanter performance. During runs 58 and 59 the organic was heated to approximately $50^{\circ} \mathrm{C}$ during the second five hours of steam stripping by heating the organic being recirculated from the $O E$ to the RCD. Diphenylamine solubility increases $10 \%$ by increasing the temperature from $28^{\circ} \mathrm{C}$ to $40^{\circ} \mathrm{C}$ and biphenyl solubility increases $34 \%$ by increasing the temperature from $28^{\circ} \mathrm{C}$ to $40^{\circ} \mathrm{C}$. Increasing the temperature should increase decanter extraction efficiency if it is being limited by solubility.

A comparison of the biphenyl stripping half lives (a lower stripping half life corresponds to a faster stripping rate) for "cold" organic recirculation versus "hot" organic recirculation shows little difference in extraction efficiency as measured by the calculated biphenyl stripping half life (Table 6). The calculated biphenyl stripping rates were approximately $10 \%$ higher during cold organic recirculation than hot organic recirculation.

Table 6

Calculated Biphenyl Stripping Half Lives

\begin{tabular}{|l|l|l|}
\hline Run & $\begin{array}{l}\text { Cold Recirculation } \\
\text { Biphenyl Stripping } \\
\text { Half Life, min }\end{array}$ & $\begin{array}{l}\text { Hot Recirculation } \\
\text { Biphenyl Stripping } \\
\text { Half Life, min }\end{array}$ \\
\hline 58 (New without Coalescer) & 135 & 164 \\
\hline 59 (New with Coalescer) & 77 & 86 \\
\hline
\end{tabular}

A comparison of the diphenylamine stripping rates for "cold" organic recirculation versus "hot" organic recirculation shows mixed results (Table 7). The Run 58 calculated diphenylamine stripping rates were lower and Run 59 stripping rates were higher during cold organic recirculation than hot organic recirculation. 
Table 7

Calculated Diphenylamine Stripping Half Lives

\begin{tabular}{|l|l|l|}
\hline Run & $\begin{array}{l}\text { Cold Recirculation } \\
\text { Diphenylamine } \\
\text { Stripping Half Life, } \\
\text { min }\end{array}$ & $\begin{array}{l}\text { Hot Recirculation } \\
\text { Diphenylamine } \\
\text { Stripping Half Life, } \\
\text { min }\end{array}$ \\
\hline 58 (New without Coalescer) & 296 & 390 \\
\hline 59 (New with Coalescer) & 500 & 275 \\
\hline
\end{tabular}

If solubility is limiting decanter performance, increasing temperature should have a major factor on decanter efficiency. Because of the low organic concentration of organic in the RCD during runs 58 and 59 (Table ), the solubility may not have been a factor in the decanter performance. Repeating the test at higher concentrations of high boiling organics in the decanter may improve decanter performance under these conditions.

\section{A. 6 COALESCER}

A liquid-liquid coalescer was installed in the new decanter prior to Run 59 in an attempt to improve decanter performance. The coalescer was a 12 inch thick by 17.25 inch diameter co-knit of $304 \mathrm{~L}$ stainless steel wire and teflon fiber manufactured by ACS Industries, Inc. The coalescer is designed to bring together fine suspensions into larger droplets for more efficient gravity separation.

The addition of the coalescer appeared to double the net stripping rate of biphenyl as compared to Run 58 (Table 6). The coalescer appeared to have a slight negative impact on the extraction of diphenylamine. More testing of the coalescer is needed to verify that it will not be plugged by mercury or other solids. Inspections after three runs indicated there was no buildup of solids in the coalescer. The coalescer could also be installed in the downcomer section of the original decanter.

The ineffectiveness of improving the extraction efficiency of diphenylamine makes the addition of a coalescer less desirable. Since diphenylamine is the most difficult to remove from the PHA, any improvements to the decanter should lead to improvements in diphenylamine stripping or extraction. The DWPE RCD is a one piece vessel, not a condenser bolted to a decanter similar to PHEF. Any pluggage to coalescer would require cleaning in place since dismantling the DWPF RCD to remove the coalescer is virtually impossible in the one piece welded vessel. 
B. DECANTER PEREOBMANCE WITH IUATE WASH EIOWSHEET

Runs 60-63 studied decanter performance during the late wash process. The late wash process was designed to produce much less high boiling organic than the HAN process. Because of this, decanter performance is expected to be better than was experienced in the HAN process.

All late wash testing was done without organic recirculation to determine whether recirculation was required with the new process. An OE cycle was performed at the completion of each run to recirculate organic vapor to the $R C D$ to clean the condenser tubes and replace the decanter organic with fresh benzene. This was designed to quantify the high boiling organic production in the late wash process and ensure that all runs began with the same starting conditions in the decanter. A summary of run 60-63 is listed in Appendix $B$ and run 60-63 analytical data is listed in Appendix C

\section{B.1 DECANTER OVERAII EFEECTIVENESS IN LATE WASH PROCESS}

Long term decanter effectiveness in the late wash process will be good because of the low production of high boiling organics. The new decanter had higher extraction efficiency during stripping and was better at self cleaning than the existing decanter. The higher extraction efficiency of the new decanter should lead to a 50 \% lower high boiling organic content in the PHA. This should lead to less operational problems and cleaning downtime in DWPF.

The most important long term predictor of performance is the self-cleaning ability of the new decanter. The new decanter is superior to the original decanter in its ability to flush high boiling organics from the decanter during feeding. It is expected that the long term performance of the original decanter will be lower than with the new decanter unless the decanter is cleaned frequently using organic vapor recirculation from the $O E$ or organic liquid recirculation is used. Long term studies without organic vapor recirculation are needed to determine how many runs the decanter can go without cleaning before extraction efficiency is affected. A summary of the late wash flowsheet decanter study is listed in Table 10:

Table 10

Summary of Decanter Testing with Late Wash flowsheet

\begin{tabular}{|l|l|l|l|l|}
\hline PHEF Runs & Description & Decanter & Effectiveness & $\begin{array}{l}\text { DWPE } \\
\text { Usefulness }\end{array}$ \\
\hline 60,61 & $\begin{array}{l}\text { No organic } \\
\text { recirculation }\end{array}$ & $\begin{array}{l}\text { New with } \\
\text { Coalescer }\end{array}$ & Excellent & Good \\
\hline 62,63 & $\begin{array}{l}\text { No organic } \\
\text { recirculation }\end{array}$ & Original & Very Good & Good \\
\hline
\end{tabular}




\section{B. 2 DECANTER TESTING IN LATE WASH PROCESS}

The late wash decanter studies were carefully controlled to minimize the impact of variations in benzene generation, high boiling organic generation, or buildup of high boiling organics on the RCD condenser on interpreting results of the decanter studies. All four runs (Runs 60-63) were operated under the same slurry feed rate, nitrogen flow, boilup rate, hold time, and within parameters specified for the chemistry in the PHT and PR heel. Each run began with the same conditions in the decanter by completing an OE cycle each run and cleaning the RCD condenser and decanter with organic vapor at the beginning of each OE cycle. Runs 62 and 63 included the addition of biphenyl to the PHT $(2000 \mathrm{mg} / \mathrm{L})$ to simulate the radiolysis products in the slurry feed. Biphenyl addition was excluded from Runs 60 and 61 to allow the calcilation of high boiling organic production in the late wash flowsheet.

Runs 60 and 61 were operated with the new decanter and coalescer installed (identical decanter equipment as run 59). Runs 62 and 63 were operated with the original decanter. All four runs were operated without organic recirculation. This is because this is the simplest operating strategy for DWPF and should be used if effective. Organic recirculation has the possibility of transferring radioactive cesium and strontium to the $O E$ if aqueous is entrained in the organic. The new decanter was specifically designed to allow operation without organic recirculation.

Results from Runs 60 through 63 will only give performance over the short term although long term predictions can be made. The cleaning of the condenser and decanter at the end of every run had the effect of starting each run in the same condition as will be seen in the first cold chemical run.

The decanter performance is based on the following data which was collected for each run:

1. Self cleaning ability of decanter- compares decanter organic concentration before and after feeding. Since most of the benzene is generated during feed, this is good estimate of the long term effectiveness of the decanter. A self cleaning decanter will have a lower high boiling organic concentration at the end of feeding than at the start.

2. High boiler stripping half life-this measures the net stripping of the decanter during aqueous boil. At identical conditions the net stripping half life is a measure of extraction efficiency. 
3. Extraction efficiency- this compares the inlet liquid stream to the Decanter (a condensate sampler collects these samples) to the aqueous return sample.

4. Aqueous return concentrations- this is an indirect measure of the decanter extraction efficiency, since inefficient extraction will lead to higher organic return to the PR.

\section{B.3 SELE CLEANING ABILITY OF DECANTER}

Both decanters replaced the diphenylamine in the decanter organic with virtually pure benzene during feeding. The new decanter replaced a higher percentage of biphenyl with benzene while the original decanter increased in biphenyl concentration. The data is summarized in Tables 16 and 17.

Table 16

Decanter Biphenyl Concentration During Feed

\begin{tabular}{|l|l|l|l|}
\hline Run & $\begin{array}{l}\text { RCD Organic } \\
\text { Pre-Rxn } \\
\text { mg/L }\end{array}$ & $\begin{array}{l}\text { RCD Organic } \\
\text { Post-Feed, } \\
\text { mg/L }\end{array}$ & \% change \\
\hline 60 (New) & 4,516 & 3,528 & $-28 \%$ \\
\hline 61 (New) & 3,376 & 3,427 & $-1 \%$ \\
\hline 62 (Original) & 1,282 & 12,940 & $90 \%$ \\
\hline 63 (Original) & 2,355 & 7,980 & $70 \%$ \\
\hline
\end{tabular}

Table 17

Decanter Diphenylamine Concentration During Feed

\begin{tabular}{|l|c|c|c|}
\hline Run & $\begin{array}{l}\text { RCD Organic } \\
\text { Pre-Rxn } \\
\text { mg/L }\end{array}$ & $\begin{array}{l}\text { RCD Organic } \\
\text { Post-Feed, } \\
\text { mg/L }\end{array}$ & $\%$ change \\
\hline 60 (New) & 1,415 & 380 & $-272 \%$ \\
\hline 61 (New) & 1,281 & 341 & $-276 \%$ \\
\hline 62 (Original) & 620 & 188 & $-230 \%$ \\
\hline 63 (Original) & 892 & 214 & $-317 \%$ \\
\hline
\end{tabular}

\section{B.4 HIGB BOILER NET STRIPPING HALE IIEE}

The diphenylamine net stripping half life during aqueous boil averaged 115 minutes during runs 60 and 61 and averaged 165 minutes during runs 62 and 63 . The biphenyl net stripping half life during aqueous boil could not be measured during runs 60 and 61 because of the low biphenyl concentrations at the beginning of aqueous boil (no biphenyl was added to the slurry during runs 60 and 61 ). The biphenyl net stripping half life during aqueous boil averaged 39 minutes during runs 62 and 63 . The data is summarized in Table 14.

The net decanter extraction efficiency is higher for the new decanter than the original decanter, as measured by the diphenylamine stripping half life. No comparisons can be made based on the biphenyl stripping half lives but it can be 
noted that biphenyl was readily stripped from the PHA in both decanter designs. Figures 60-1 through 63-1 summarize the PR diphenylamine and biphenyl concentrations during stripping.

Table 14

Calculated Stripping Half Life

\begin{tabular}{|l|c|c|}
\hline Run with & $\begin{array}{l}\text { Biphenyl Stripping } \\
\text { Half Life, min }\end{array}$ & $\begin{array}{l}\text { Diphenylamine } \\
\text { Stripping Half Life, min }\end{array}$ \\
\hline $\begin{array}{l}60 \text { (New wot Calculated } \\
\text { coalescer) }\end{array}$ & Not Calculated & 121 \\
\hline $\begin{array}{l}\text { ó (New with } \\
\text { coalescer) }\end{array}$ & 55 & 178 \\
\hline 62 (Original) & 23 & 151 \\
\hline 63 (Original) & & \\
\hline
\end{tabular}

\section{B.5 EXTRACTION EFFICIENCY}

The calculated diphenylamine extraction efficiency during aqueous boil averaged $81.2 \%$ during runs 60 and 61 and averaged $47.9 \%$ during runs 62 and 63 . The calculated biphenyl extraction efficiency during aqueous boil averaged $81.9 \%$ during runs 60 and 61 and averaged $71.2 \%$ during runs 62 and 63. The data is summarized in Table 15.

Table 15

Calculated Extraction Efficiency

\begin{tabular}{|l|c|c|}
\hline Run & $\begin{array}{l}\text { Biphenyl Extraction } \\
\text { Efficiency }\end{array}$ & $\begin{array}{l}\text { Diphenylamine } \\
\text { Extraction Efficiency }\end{array}$ \\
\hline $\begin{array}{l}\text { ó (New with } \\
\text { coalescer) }\end{array}$ & $86.8 \%$ & $82.8 \%$ \\
\hline $\begin{array}{l}61 \text { (New with } \\
\text { coalescer) }\end{array}$ & $77.0 \%$ & $79.5 \%$ \\
\hline 62 (Original) & $51.4 \%$ & $20.9 \%$ \\
\hline 63 (Original) & $91.0 \%$ & $74.8 \%$ \\
\hline
\end{tabular}

The calculated decanter extraction efficiency is lower with the original decanter than the new decanter. There is a significant difference between runs 62 and 63 with the original decanter. It is likely that the original decanter had some residual diphenylamine in the aqueous portion that was not cleaned out prior to installation prior to run 62 .

\section{B. 6 AQUEOUS RETURN CONCENTRATIONS}

The new decanter had a higher extraction efficiency for both biphenyl and diphenylamine than the original decanter, as measured by the organic entrainment in the aqueous return samples. The new decanter had a higher extraction efficiency for biphenyl than diphenylamine. The aqueous return data is summarized in Table 18. 
Table 18

Aqueous Return Results (Aqueous Boil)

\begin{tabular}{|l|c|c|}
\hline Run & $\begin{array}{l}\text { Average Biphenyl } \\
\text { Concentration, mg/L }\end{array}$ & $\begin{array}{l}\text { Diphenylamine } \\
\text { Concentration, } \mathrm{mg} / \mathrm{L}\end{array}$ \\
\hline $60(\mathrm{New})$ & 7.1 & 13.9 \\
\hline 61 (New) & 6.6 & 14.3 \\
\hline 62 (Original) & 41.0 & 27.5 \\
\hline 63 (Original) & 20.6 & 17.8 \\
\hline
\end{tabular}

\section{B. 7 DIFEERENCES IN LATE WASH PROCESS}

The late wash flowsheet has a number of features that distinguish it from the HAN flowsheet. Feed temperature is $90^{\circ} \mathrm{C}$ for late wash versus $55^{\circ} \mathrm{C}$ for HAN. The hold period (similar to the organic boil section for the HAN flowsheet) also occurs at $90^{\circ} \mathrm{C}$. Considerable stripping of biphenyl in particular is occurring in the late wash flow sheet as a result of the seven hours during feed and hold at $90^{\circ} \mathrm{C}$. The total time for the late wash $F R$ cycle is 945 minutes versus 900 for HAN. The typical HAN PR cycle is summarized in Table 11, The late wash PR cycle is summarized in Table 12.

Table 11

HAN PR cycle summary

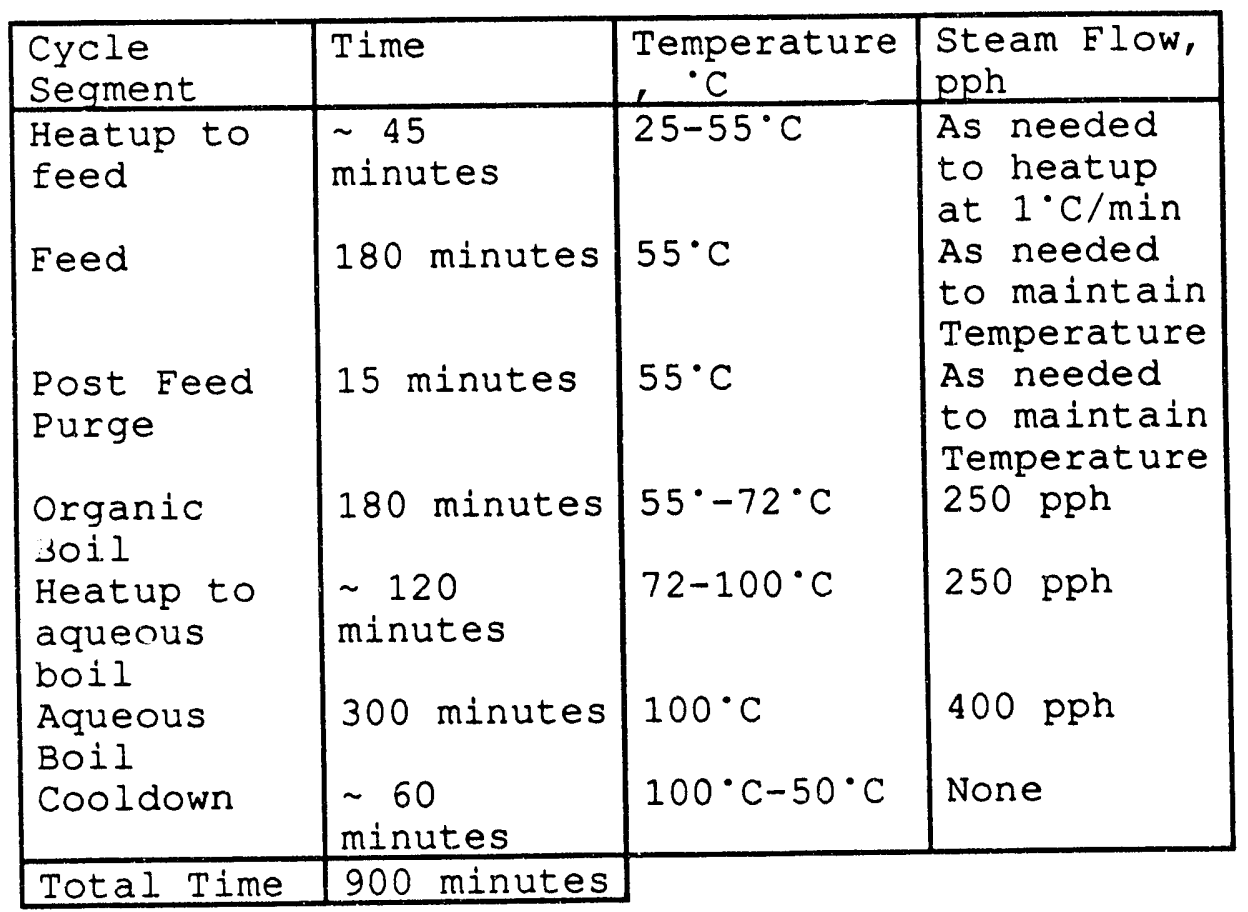


Table 12

Late Wash PR cycle summary

\begin{tabular}{|c|c|c|c|}
\hline $\begin{array}{l}\text { Cycle } \\
\text { Segment }\end{array}$ & Time & $\begin{array}{l}\text { Temperature } \\
, \quad \mathrm{C}\end{array}$ & $\begin{array}{l}\text { Steam Flow, } \\
\text { pph }\end{array}$ \\
\hline $\begin{array}{l}\text { Heatup to } \\
\text { feed }\end{array}$ & $\begin{array}{l}\sim 90 \\
\text { minutes }\end{array}$ & $25-90^{\circ} \mathrm{C}$ & $\begin{array}{l}\text { As needed } \\
\text { to heatup } \\
\text { at } 1^{\circ} \mathrm{C} / \mathrm{min}\end{array}$ \\
\hline Feed & 120 minutes & $90^{\circ} \mathrm{C}$ & $\begin{array}{l}\text { As needed } \\
\text { to maintain } \\
\text { Temperature }\end{array}$ \\
\hline $\begin{array}{l}\text { Post Feed } \\
\text { Purge }\end{array}$ & 15 minutes & $90^{\circ} \mathrm{C}$ & $\begin{array}{l}\text { As needed } \\
\text { to maintain } \\
\text { Temperature }\end{array}$ \\
\hline Hold & 300 minutes & $90^{\circ} \mathrm{C}$ & $\begin{array}{l}\text { As needed } \\
\text { to maintain } \\
\text { Temperature }\end{array}$ \\
\hline $\begin{array}{l}\text { Heatup to } \\
\text { aqueous } \\
\text { boil }\end{array}$ & $\begin{array}{l}\sim 60 \\
\text { minutes }\end{array}$ & $90-100^{\circ} \mathrm{C}$ & $250 \mathrm{pph}$ \\
\hline $\begin{array}{l}\text { Aqueous } \\
\text { Boil }\end{array}$ & 300 minutes & $100^{\circ} \mathrm{C}$ & $400 \mathrm{pph}$ \\
\hline Cooldown & $\begin{array}{l}\text { } 60 \\
\text { minutes }\end{array}$ & $100^{\circ} \mathrm{C}-50^{\circ} \mathrm{C}$ & None \\
\hline Total Time & 945 minutes & & \\
\hline
\end{tabular}

\section{c. OTHER CONSIDERATIONS FOR IMPROVING PHA OUALITY}

There are other process changes which could be made to improve the overall quality of the PHA product. The strongest factors on the quality of the PHA (from a high boiling organic standpoint) are (1) production of high boiling organics, (2) stripping rate of high boiling organics from PR, and (3) extraction efficiency of high boiling organics. A combination of minimizing production, maximizing stripping and maximizing extraction will produce the highest quality PHA product.

\section{C.1 MINIMIZING PRODUCTION OF HIGH BOIIING ORGANICS}

Minimizing the production of high boiling organics is the most effective method for ensuring that the highest quality PHA is produced. The late wash process produces far lower quantities of high boiling organics and is the most important factor in maximizing PHA quality. Any further reductions in the high boiling organic production would further improve PHA quality.

Minimizing the nitrite concentration also has the effect of minimizing the production of diphenylamine. Since diphenylamine is the most difficult of the high boiling organics to remove from the PR, this will be effective in further improving the quality of the PHA. 

J. T. CARTER
PAGE
19
WSRC-RP-92-996

\section{C.2 MAXIMIZING THE STRIPPING OF HIGH BOIIING ORGANICS}

Maximizing the stripping of high boiling organics can be accomplished by increasing the boilup rate from $400 \mathrm{pph}$ of steam to some higher value. Doubling the boilup rate to 800 pph should decrease the PHA diphenylamine concentration by half in the PHA (assuming a five hour half life and five hours of aqueous boil).

Another method for maximizing the stripping would be to continue steam stripping as long as practicable. By increasing the aqueous boil period from five to twenty hours, the PHA diphenylamine concentration should decrease by a factor of eight (assuming a five hour stripping half life).

A third option for maximizing stripping is to increase the feed and hold temperatures above $90^{\circ} \mathrm{C}$. These combined periods last approximately seven hours so a small increase in temperature may lead to a noticeable increase in stripping.

\section{C.3 MAXIMIZING EXTRACTION OF HIGH BOIIING ORGANICS}

Maximizing extraction efficiency of the decanter can be accomplished by a number of methods:

1) production of more benzene/less high boiling organics will increase extraction efficiency in the decanter and require a shorter stripping time. One advantage of the late wash process is there is more benzene produced to extract a lower source term of high boiling organics. Lowering the nitrite concentration will lower the production of diphenylamine which is the limiting high boiling organic to be stripped.

2) Install a decanter which is more efficient in purging itself of high boiling organics.

3) Clean the condenser and decanter by recirculating organic vapors from the $O E$ to the RCD. This could be used as a periodic cleanup by installing a jumper to reroute the $O E$ vapor from the ECD to the RCD. The organic vapors will clean any deposits of high boiling organics from the condenser tubes and dilute the high boiling concentration of the decanter with virtually pure benzene. This may replace the need for organic liquid recirculation.

4) Install packing or coalescer to improve the extraction efficiency of the decanter.

5) Increase the stripping in the PR cycle. This could be accomplished by a number of methods which could be used separately or together to lower the concentration of high boiling organics including: 
a) Increase stripping time by shortening the feed time from the current two hours to the minimum feed time of 36 minutes (20 gpm PHEF or $100 \mathrm{gpm}$ DWPE).

b) Increase stripping time by shortening the hold time from five hours to two hours by taking credit for the catalytic activity of the mercury which will be present in DWPF.

c) Increase the boilup rate during aqueous boil by $50 \%$ to effectively increase the stripping time from 5 to 7.5 hours.

d) Increase stripping time by eliminating an OE cycle each $P R$ cycle or running the $O E$ and $P R$ cycles concurrently. The cycle time used for the $O E$ cycle could be used for extended stripping.

A DWPF salt cell cycle time study is necessary to determine the effectiveness of any or all of these methods in improving the quality of the PHA.

\section{DECANTER DISCUSSION}

Hydrolysis of Tetraphenylborate (TPB) in the presence of nitrite results in the production of polycyclic aromatics and aromatic amines (referred as high boiling organics) such as biphenyl, diphenylamine, terphenyls, etc. in the Precipitate Reactor (Figure 1). During the aqueous boil section of the process, the high boiling organics are steam stripped from the PR to the Reactor Condenser/Decanter (RCD) where they are condensed in the condenser and extracted in the benzene phase of the decanter. The decanter separates the organic (benzene) and aqueous phases by gravity, based on the differences in density of the two phases. The high boiling organic separation is difficult because although the high boiling organics are highly soluble in benzene, they also have densities higher than benzene or water. Any carryover of high boiling organics into the aqueous phase will result in returning these organics to the PR.

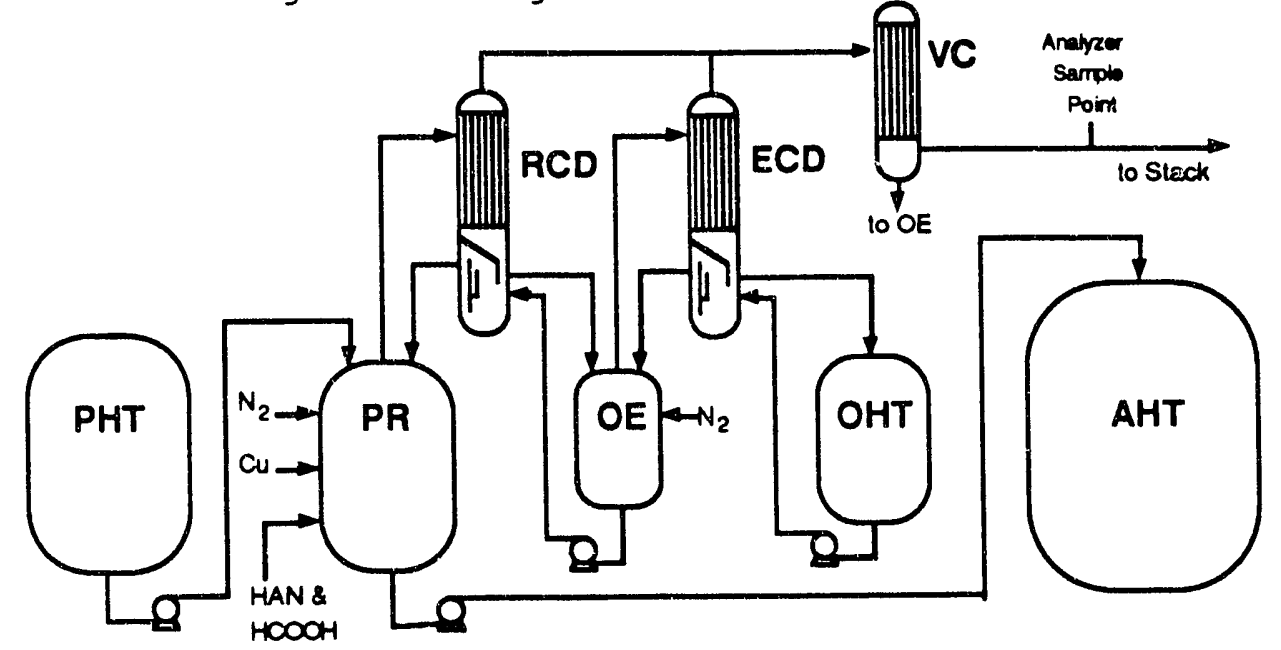

Figure 1. PHEF Diagram 
Maximum organic removal of the organics in the decanter will lead to minimum high boiling organic content in the PHA. A number of strategies were proposed in maximizing organic removal. The late wash process also has the added advantage that its lower nitrite concentration will lead to lower production of diphenylamine. Diphenylamine is much more difficult to remove from the PHA because its vapor pressure is approximately $1 / 5$ th the vapor pressure of biphenyl at $100^{\circ} \mathrm{C}[1]$. This requires that roughly five hours of stripping are needed to steam strip the same amount of diphenylamine from PHA as one hour for biphenyl.

\section{D.1 ORGANIC PRODUCTION, AC:CUMULATION AND DIEFICULTIES}

The reactions thought to be responsible for the production of biphenyl, phenol, and the terphenyls involve free radicals. The reactions involved in the production of aniline and diphenylamine are not clearly understood but the amount of aniline and diphenylamine produced during hydrolysis increase with increasing nitrite concentration.

Based on the results of the previous studies, it was concurred that the current decanter design is not providing adequate separation of the high boiling organics. The poor extraction leads to high concentrations of high boiling organics in the PHA. This has been measured in PHEF by excessive carry over of organics into the aqueous that is recycled to the precipitate Reactor.

The PHEF process simulations have indicated the organic accumulation within the process vessels, piping, flame arrestors and the sample taps. The non-polar organic content of the precipitate hydrolysis aqueous product will cause several problems in the DWPF Chemical Process Cell including organic accumulation in the SRAT Condenser tubes, MWWT (Mercury Wash Water Tank), the SRAT vessel vent header, and the sample lines from the vessel to the analyzers. The higher the concentration of these organics in the product, the greater the frequency of cleaning that will be needed to operate these facilities. Operation of the Sludge Receipt and Adjustment Tank (SRAT) and Slurry Mix Evaporator (SME) will unintentionally steam strip these high boiling organics from the SRAT or SME to the condensers, vent piping, and sample lines where problems have been observed in IDMS.

The accumulation of high boiling organics within process vessels and piping can reduce heat transfer and obstruct fluid flow. The PR and PRCD cooling surfaces are especially susceptible to deposits of high boiling organics. The high boiling organics are believed to solidify on the cold surface. 


\section{D.2 DECANTER DESIGN STRATEGY}

The RCD is a combination condenser and decanter in the same vessel body (Figure 1). The condenser sits on top of the decanter and the condensate drains by gravity to the decanter. The decanter is designed to decant (separation of a stream into two liquid phases using the force of gravity) benzene/organics, water/water soluble chemicals, and mercury. The low specific gravity of the upper organic layer $10.88-$ $0.92)$ allows the separation by gravity of a lower aqueous layer (1.00) with an accumulation of a small layer of mercury $(13.6)$ in the base of the decanter [2].

The interface level between the organic and aqueous is controlled by the height difference between the organic and aqueous weirs. The weir height difference is fabricated to maintain approximately $50 \%$ organic and $50 \%$ aqueous in the decanter. Excess aqueous overflows and returns to the PR. Excess organic overflows and returns to the OE. Any cesium or strontium that reaches the RCD will be returned to the PR because of the high solubility of cesium and strontium in the aqueous relative to the organic phase.

The decanter is a batch process which has two very different purposes. (1) During feed and organic boil (HAN Flowsheet) or feed and hold period (Late Wash Flowsheet), benzene is generated, vaporized, condensed and decanted from the aqueous in the decanter. The organic is rich in benzene during organic boil since the high boiling organics have much lower vapor pressures than benzene. Approximately 50 gallons of benzene is generated each run versus approximately 15 gallons of decanter organic inventory. (2) During aqueous boil $\left(100^{\circ} \mathrm{C}\right.$ for five hours), the high boiling organics are steam stripped from the reactor to the $\mathrm{RCD}$ and extracted by the decanter organics. The extraction is a maximum one equilibrium stage. The steam stripping/extraction continues for five hours to minimize the concentration of high boiling organics in the aqueous product.

\section{3 PRINCIPLES OF ORIGINAL AND NEW DECANTER}

The original decanter design is shown in Figure 2. The condensate from the condenser drops from the condenser tubes, which are arranged in a doughnut shape at the outer $1 / 3$ of the condenser body, into the decanter. The condensate drops onto the baffle plate or directly into the downcomer section of the decanter. The downcomer extends vertically six inches into the organic layer. The organics are extracted or decanted in the organic layer and overflow from the organic weir to the OE. The aqueous is decanted from the organic, overflows from the aqueous weir to the PR [3]. 


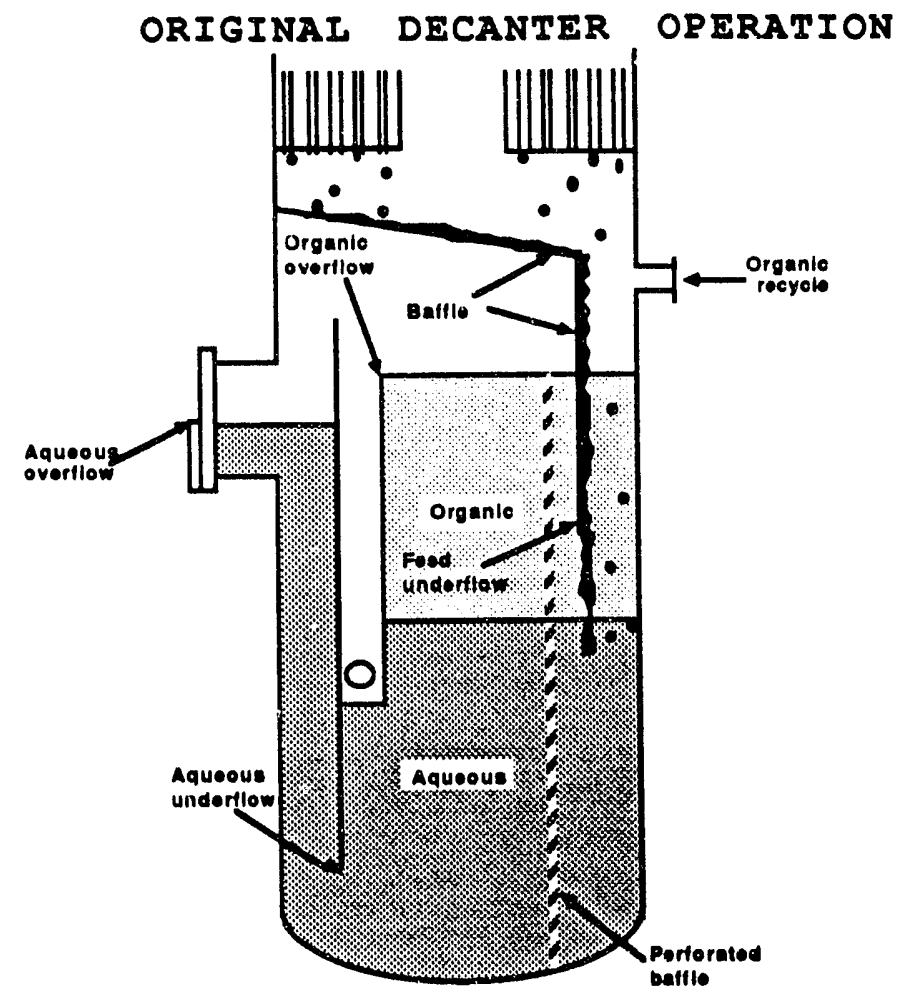

The new decanter design is shown in Figure 3 . The condensate from the condenser drops from the condenser tubes, which are arranged in a doughnut shape at the outer $1 / 3$ of the decanter body, into the decanter. The condensate drops directly into the organic layer since there is no baffle or downcomer. The organics are extracted or decanted in the organic layer, are removed near the organic/aqueous interface, and overflow from the organic weir to the $O E$. The aqueous is decanted from the organic, overflows from the aqueous weir to the PR [4].

Stops were fabricated to allow the installation of packing or a coalescing element in the organic layer to improve mixing and coalescing in the decanter. 


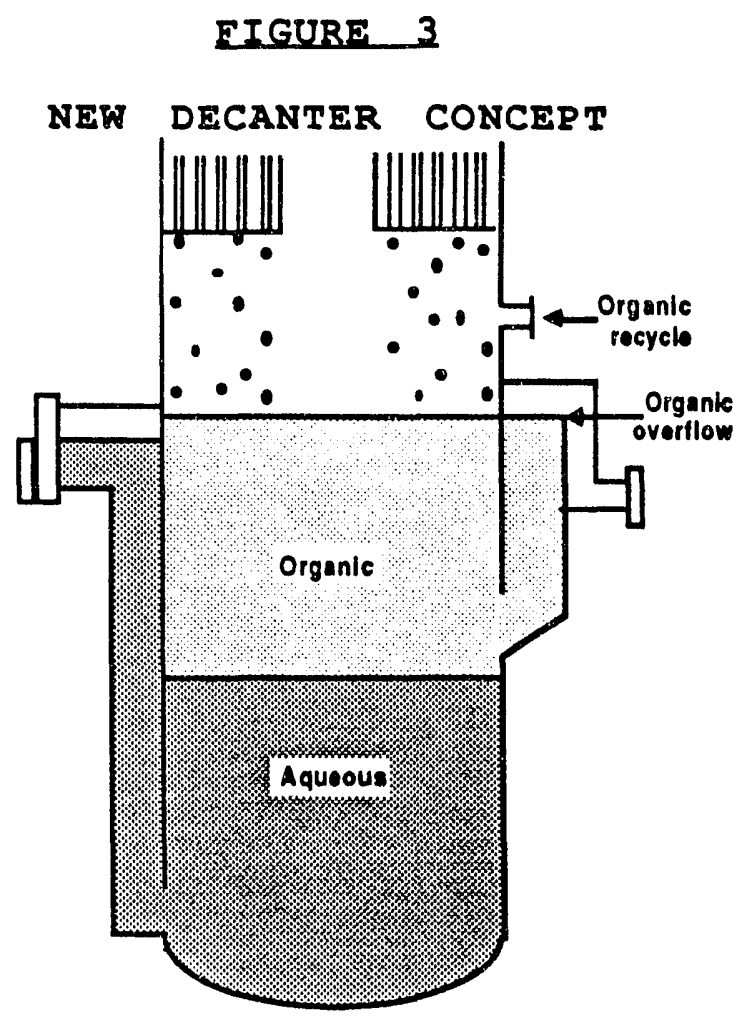

\section{D.4 DECANTER OPERATING STRATEGY}

Experience during HAN operations determined that recirculation of organic liquid from the OE to the RCD decanter is the most effective in improving extraction efficiency and minimizing entrainment [5]. Organic liquid recirculation is believed to improve decanter performance by (1) diluting the high boiling organic concentration in the decanter, (2) maximizing the volume of organic that can be used for extraction, (3) minimizing entrainment by minimizing the buildup of high boiling organics at the organic/aqueous interface, and (4) increasing extraction efficiency by improving the mixing between the aqueous and organic phases. The residence time for both the aqueous and organic phase is approximately fifteen minutes with organic recirculation. without recirculation, the organic residence time is the time between one run and the next (generally two - six weeks) since virtually all the benzene has been produced and vaporized by the start of aqueous boil.

\section{5 DECANTER PROBLEMS}

Experience shows that the long term performance of the decanter deteriorates over time because of the buildup of high boiling organics in the decanter from run to run. Part of the reason for this is the large amount of high boiling organics produced versus the low amount of benzene produced. 
As the high boiling organic concentrations increase, the aromatic content in the organic starts to approach solubility limits, and the extraction efficiency of the decanter decreases. The solubility of biphenyl and diphenylamine in benzene are listed in Table 1 [6].

Table 1

Diphenylamine and Biphenyl Solubility in Benzene

\begin{tabular}{|c|c|c|}
\hline Temp, ${ }^{\circ} \mathrm{C}$ & $\begin{array}{l}\text { Diphenylamine } \\
\text { Solubility, wt } \\
8\end{array}$ & $\begin{array}{l}\text { Biphenyl } \\
\text { Solubility, } \\
\text { wt o }\end{array}$ \\
\hline 0 & 52.5 & 8.1 \\
\hline 28 & 73.5 & 26.1 \\
\hline 40 & 80.6 & 43.2 \\
\hline
\end{tabular}

A problem encountered in allowing the batch decanter to sit for long periods between runs is that the higher density organics concentrate near the organic/aqueous interface. Fragments of organic can be trapped on the aqueous side of the interface as a fine "secondary dispersion" [7]. The high boiling organics also have a higher density than benzene (diphenylamine $1.16 @ 22^{\circ} \mathrm{C}[6]$, biphenyl $0.9939 @ 70^{\circ} \mathrm{C}$ [8]) so they tend to drop to the bottom of the decanter once their solubility is exceeded. These high boiling organics will be returned to the $\mathrm{PR}$ at the beginning of stripping during the next run.

A third problem experienced with the decanters is the effect of process upsets on decanter efficiency. Experience has shown that initiation of flow can cause excessive entrainment of organic in the aqueous. This has happened at the onset of aqueous boil and after steam interruptions during aqueous boil.

\section{6 ESTIMATES OF DECANTER PERTORMANCE}

A combination of two factors are necessary to determine the performance of the decanter, 1) what is the steam stripping rate for removal of high boiling organics from the $P R$ and 2) what is the organic removal efficiency of the organics in the decanter. Both of these quantities are difficult to measure in PHEF. The net stripping rate can be estimated by calculating a stripping rate from the PR high boiling organic concentration during aqueous boil. The calculational method for making these calculations are listed in Appendix A. This method also calculates a net stripping half life which is defined as the time it will take to remove half of the high boiling organi ss from the $P R$, similar to a radioactive half liie. Where appropriate, the net stripping half life will be calculated for comparisons of different decanter operating strategies. 
It is difficult to directly measure the decanter extraction efficiency of the high boiling organics. Efforts at determining the high boiling extraction efficiency of the decanter by comparing an equilibrium aqueous concentration to the measured aqueous concentration exiting the decanter showed the estimated efficiency varied greatly but was generally very low (1 to 10\% of equilibrium) [9]. A good measure of the decanter extraction efficiency is the concentration of high boiling organics in the aqueous return to the PR. This is measured directly by pulling samples.

The concentration of high boiling organics in the PR is not a good measure of the organic concentration entering the decanter because the high boiling organics have a tendency to plate out on cold heat exchanger surfaces such as the RCD condenser tubes. As a result, a condensate sampler was installed after Run 57 to directly measure the organic content of the liquid entering the decanter. A ratio of aqueous return concentration to condenser condensate concentration gives a direct measure of decanter extraction efficiency.

Decanter performance can be effected by a number of parameters including: 1) high boiling organic production during run, 2) high boiling organic content of organic in decanter, and 3) upsets during run. From run to run the high boiling organic concentration varied significantly (Table 2 summarizes PR high boiling concentrations for runs 54-63). Also, the organic concentration in the decanters varied significantly from run to run (Table 3 summarizes decanter organic concentrations). The higher the organic concentration, the lower the volume of benzene in the decanter, so the useful volume for extraction is lower. Any process upset such as loss of steam or start of aqueous boil has a tendency to upset the decanter by increasing entrainment of organics in the aqueous.

TABLE 2

PR AQUEOUS ORGANIC CONCENTRATION DURING STRIPPING

\begin{tabular}{|c|c|r|r|r|}
\hline RUN & $\begin{array}{l}\text { BIPHENYL } \\
\text { BEFORE }\end{array}$ & $\begin{array}{l}\text { BIPHENYL } \\
\text { AFTER }\end{array}$ & $\begin{array}{l}\text { DIPHENYLAMINE } \\
\text { BEFORE }\end{array}$ & $\begin{array}{l}\text { DIPHENYLAMINE } \\
\text { AFTER }\end{array}$ \\
\hline 54 & 1725 & 290 & 906 & 1158 \\
55 & 1096 & 150 & 667 & 1033 \\
56 & 1540 & 144 & 1489 & 747 \\
57 & 1171 & 1187 & 310 & 828 \\
58 & 599 & 148 & 1055 & 298 \\
59 & 1061 & 6 & 959 & 271 \\
60 & 41 & 1 & 130 & 23 \\
61 & 18 & 3 & 104 & 17 \\
62 & 478 & 6 & 146 & 41 \\
63 & 302 & 2 & 133 & 23 \\
\hline
\end{tabular}




\section{DECANTER ORGANIC CONCENTRATION}

\begin{tabular}{|c|c|c|c|c|}
\hline RUN & $\begin{array}{c}\text { BIPHENYL } \\
\text { BEFORE } \\
\text { REACTION }\end{array}$ & $\begin{array}{c}\text { BIPHENYL } \\
\text { AFTER RUN }\end{array}$ & $\begin{array}{c}\text { DIPHENYLAMINE } \\
\text { BEFORE REACTION }\end{array}$ & $\begin{array}{c}\text { DIPHENYLAMINE } \\
\text { AFTER RUN }\end{array}$ \\
\hline 54 & 83,274 & 116,687 & 35,764 & 38,645 \\
55 & 70,841 & 109,497 & 10,373 & 23,326 \\
56 & 44,943 & 101,152 & 1,748 & 36,386 \\
57 & 114,879 & 105,554 & 23,161 & 30,976 \\
58 & 34,662 & 37,905 & 1,752 & 12,832 \\
59 & 9,962 & 11,788 & 6,530 & 9,696 \\
60 & 5,098 & 11,357 & 768 & 8,710 \\
61 & 5,361 & 8,041 & 741 & 6,546 \\
62 & 1,282 & & 620 & \\
63 & 2,355 & & 892 & \\
\hline
\end{tabular}

\section{QUATITY ASSURANCE}

The accuracy of analytical results were controlled by bracketing the analytical results with check standards which were controlled to within 5\% (except liquid chromatography results) of their nominal values. The liquid chromatography results were controlled via check standards that were controlled to within $10 \%$ of their nominal values. The analytical results are stored in the Laboratory Information Management Software stored on the VAX in 679-T.

All Process run data are stored in the Vantage ${ }^{\mathrm{TM}}$ data collection system running on the VAX computer located in 679T. A registered data notebook, , WSRC-NB-90-178, pages 17136, was used to record data related to Runs 51 and 54-63. A run notebook containing the approved run plan, all procedures pertaining to the run, the sample schedule, and run preparation calculations and parameters is retained for each each run. 


\section{Beferences}

1. Seidell, Solubilities of Organic Compounds, 3rd Edition, volume 2 .

2. R. W. Cox, "Precipitate Hydrolysis Experimental Facility, Project Design Bases", Savannah River Site Document, Project 9S4095, February 25, 1987.

3. M. A. Baich, "Accumulation of Organic High Boilers in the DWPF Salt Processing Cell Decanters", Savannah River Site Document WSRC-RP-89-545, July 13, 1989.

4. M. A. Baich, R. E. Eibling, R. A. Jacobs, W. J. Jenkins, J. C. Marek, H. B. Shah, S. R. Young, "PHEF Decanter Extraction Efficiency Task Team Interim Report 3)", Savannah River Site Document SRL-PTD-910090, September 23, 1991.

5. M. A. Baich, R. E. Eibling, R. English, R. A. Jacobs, W. J. Jenkins, J. C. Marek, J. Morrison, "PHEF Decanter Extraction Efficiency Task Team Interim Report 2)", Savannah River Site Document SRL-PTD-900059 , october $12,1990$.

6. "CRC Handbook of Chemistry and Physics", 61st Edition.

7. Scheitzer, P. A., "Handbook of Separation Techniques for Chemical Engineers", Section 1.11, Decantation, McGraw-Hill Book Company, 1979.

8. J. A. Dean, "Lange's Handbook of Chemistry", Thirteenth addition.

9. M. A. Baich, R. E. Eibling, R. English, R. A. Jacobs, W. J. Jenkins, J. C. Marek, J. Morrison, "PHEF Decanter Extraction Efficiency Task Team Interim Report)", Savannah River Site Document SRL-PTD-900021 , March 30, 1990. 


\section{Appendix A}

Calculation of Stripping Rates

The decanter is designed to extract organics from the aqueous product to produce as low a concentration of high boiling organics in the PHA as practical. Only the biphenyl and diphenylamine concentrations will be discussed because of their high concentrations in the PHA and because they have been responsible for the operating difficulties such as flame arrestor pluggage. The decrease in concentration over time appears to be an exponential decay and can be modelled by the following equation:

$\mathrm{C}(\mathrm{t})=\mathrm{C}_{0} * \exp \left(\mathrm{k}_{1} \mathrm{t}\right)$

$\mathrm{C}_{0}=$ Initial concentration in $\mathrm{PR}, \mathrm{mg} / \mathrm{L}$

$\mathrm{C}(\mathrm{t})=$ Concentration in $\mathrm{PR}$ at time $\mathrm{t}, \mathrm{mg} / \mathrm{L}$

$\mathrm{t}=$ time, minutes

$\mathrm{k}_{1}=$ stripping constant, $\min ^{-1}$

From equation (1), a half life can be calculated which is a measure of the time it will take to reduce the high boiling organic concentration by half.

$\mathrm{t}_{1 / 2}=-\ln (2) / \mathrm{k}_{1}=-0.693 / \mathrm{k}_{1}$

$t_{1 / 2}=$ stripping half life, minutes

This half life calculation can be used to calculate the stripping time required to reduce an initial concentration to a final concentration as follows:

$\mathrm{t}($ stripping $)=\mathrm{C}_{0} / \mathrm{C}_{\text {target }} * \mathrm{t}_{1 / 2}$

$\mathrm{t}($ stripping $)=$ stripping time required

$\mathrm{C}_{\text {target }}=$ Target high boiling organic concentration at end of stripping, $\mathrm{mg} / \mathrm{L}$ 
Appendix B

Run Summaries

The following information summarizes the runs used to test decanter performance. The summary will highlight any differences during runs which may have affected decanter performance.

\section{Run 54 Summary}

Run 54 was the first of two runs to evaluate (1) the effectiveness of spray nozzles for the recirculation of the organic recycle from the $O E$ to the $R C D$ during aqueous boil and (2) aqueous drawoff. The spray nozzles were installed in the original decanter before Run 54. The organics simulating radiolysis of TPB were added to the $P R$ after feeding. Analytical results for the run are listed in Appendix C, Tables 54-1 to 54-6.

734 gallons of slurry were fed to the PR containing a 317 gallon heel. The final volume of PHA was 910 gallons (low volume because of aqueous drawoff). The PHA contained 320 $\mathrm{mg} / \mathrm{L}$ biphenyl and $1424 \mathrm{mg} / \mathrm{L}$ diphenylamine. An OE cycle was completed.

\section{The following interruptions occurred:}

1. Two interruptions at beginning of feed caused by high $\mathrm{N}_{2} \mathrm{O}$ generation. This suggests that the nitrite concentration was higher than the target.

2. Two interruptions near the end of feeding caused by the high feed flow alarm. This is related to foam in the feed.

3. One interruption at the beginning of organic boil due to a $\operatorname{logic}$ error.

4. Interruption at beginning of aqueous drawoff caused by high PRCD vapor temperature.

Other notes:

The PHT was drained and cleaned before Run 54 because of the formation of golf ball sized solids (clunkers).

The RCD was drained to the PR to allow installation of the spray nozzles and HEME. The PR liquid was later pumped to the OE. The decanter was refilled with organic by pumping organic from OE to RCD. This method of replacing the organics in the RCD also probably helped clean the PR and OE high boiling organics and may have lowered the decanter extraction efficiency. 
Process water was added to bring aqueous level to approximately $50 \%$.

Made supernate transfer from $\mathrm{PHT}$ to $\mathrm{W}-1$ because the first transfer was low in TPB.

Surfynol (500 ppm) was added to $W-1$ before the transfer from W-1 to PHT. Additional Surfynol (250 ppm) was added to the PHT because of foaming problems. Additional Surfynol (250 ppm) was added to the PHT before feeding because of additional foam.

Nitrite was low after trim chemicals were added. Additional Sodium Nitrite was added to the PHT. 
Run 55 Summary

Run 55 was the second of two runs to evaluate (1) the effectiveness of spray nozzles for the recirculation of the organic recycle from the $O E$ to the RCD during aqueous boil and (2) aqueous drawoff. The spray nozzles were installed in the original decanter before Run 54. The organics simulating radiolysis of TPB were added to the PR after feeding. Analytical results for the run are listed in Appendix $C$, Tables 55-1 to 55-5.

680 gallons of slurry were fed to the PR containing a 317 gallon heel. The final volume of PHA was 927 gallons. The final PHA contained $101 \mathrm{mg} / \mathrm{L}$ biphenyl and $810 \mathrm{mg} / \mathrm{L}$

diphenylamine. An $O E$ cycle was completed after installation of new decanter prior to Run 56 .

\section{The following interruptions occurred:}

1. Numerous flow interruptions caused by loss of flow (related to foaming). Surfynol added and logic changed to allow lower flowrate.

2. Three interruptions during aqueous boil caused by high PRCD vapor temperature.

\section{other notes:}

The RCD was inventoried with organic by setting up flow from the OHT to the RCD.

Drummed out the $O E$ water instead of using for heel.

More surfynol(8) was added to PHT because of problems feeding (surfynol@ level $>1000 \mathrm{ppm}$ ).

Water was added to the PR and PHT (approximately 100 gallons) during the feed troubleshooting.

A cooling water valve outside of PHEF was throttled causing the high PRCD vapor temperatures. Steam flowrate was cutback to $200 \mathrm{pph}$ for 35 minutes and $300 \mathrm{pph}$ for 30 minutes during aqueous boil. 


\section{Run 56 Summary}

Run 56 was the first of two runs to evaluate (1) the new decanter design without organic recirculation and (2) aqueous drawoff. The new decanter was installed before Run 56 . The organics simulating radiolysis of TPB were added to the PR after feeding. Analytical results for the run are listeri in Appendix C, Tables 56-1 to 56-5.

700 gallons of slurry were fed to the PR containing a 317 gallon heel. The final volume of PHA was 927 gallons. The final PHA contained $144 \mathrm{mg} / \mathrm{L}$ biphenyl and $747 \mathrm{mg} / \mathrm{L}$ diphenylamine.

The following interruptions occurred:

1. High PR temperature during middle of feed $\left(65^{\circ} \mathrm{C}\right)$.

2. One interruption near the end of feeding caused by the high feed flow alarm. This is related to foam in the feed.

3. Several flow interruptions caused by loss of flow (related to foaming).

4. Two interruptions during organic boil due to high $\mathrm{N}_{2} \mathrm{O}$ concentration.

other notes:

Drummed out the $O E$ water instead of using for heel. Added potassium permanganate (500 ppm) to $w-1$ to break the foam.

Replaced the $W-1$ pneumatic pump because of diaphragm leak causing foaming of PHT.

Added additional potassium permanganate (500 ppm) to PHT to break the foam.

The RCD was inventoried with organic by setting up flow from the OHT to the RCD.

Water was added to the PR (approximately 50 gallons) during the feed troubleshooting. 
Run 57 Summary

Run 57 was the second of two runs to evaluate (1) the new decanter design with organic recirculation and (2) aqueous drawoff. The new decanter was installed before Run 56. The organics simulating radiolysis of TPB were added to the PR after feeding. Analytical results for the run are listed in Appendix C, Tables 57-1 to 57-4.

700 gallons of slurry were fed to the PR containing a 323 gallon heel. The final volume of PHA was 1220 gallons. The final PHA contained $144 \mathrm{mg} / \mathrm{L}$ biphenyl and $747 \mathrm{mg} / \mathrm{L}$

diphenylamine. Ran $O E$ cycle after replacing $R C D$ level probe.

The following interruptions eccurred:

1. Numerous flow interruptions caused by loss of flow (related to foaming).

2. One interruption at beginning of aqueous boil due to $\mathrm{N} 2$ low flow interlock.

3. Two interruptions during aqueous boil while blowing down OE bubbler level transmitters.

4. Aqueous boil stopped after approximately 240 minutes because of high $O E$ level (210 gallons).

other notes:

The RCD was inventoried with organic by setting up flow from the OHT through the OE to the RCD.

Transferred $O E$ water for heel.

An emulsion noted in $O E$.

Water was added to the PR (approximately 167 gallons) during the feed troubleshooting.

Added water three times to RCD to raise the interface. Later aqueous return valve was closed to raise interface.

A high steam flow rate (approximately $800 \mathrm{pph}$ ) during aqueous boil caused numerous operating problems and led to the shortened PR cycle. No post reaction sample was pulled. Three separate periods of aqueous boil were completed to retrieve the data which was not gathered during the first aqueous boil. A list of the tests completed in run 57 is summarized below: 
Run 57 Testing

\begin{tabular}{|l|l|l|l|}
\hline Part & $\begin{array}{l}\text { Steam Flow, } \\
\text { pph }\end{array}$ & $\begin{array}{l}\text { Aqueous Boil } \\
\text { Time }\end{array}$ & $\begin{array}{l}\text { Organic } \\
\text { Recirculation? }\end{array}$ \\
\hline A & 800 & 4 hours & Yes \\
\hline B & 400 & $\begin{array}{l}10 \text { hours } \\
2 \text { hours } \\
100\end{array}$ & Yes \\
\hline C & 100 & $\begin{array}{l}2 \text { hours } \\
5 \text { hours }\end{array}$ & No \\
\hline D & 400 & $\begin{array}{l}4 \text { hours } \\
5 \text { hours } \\
4 \text { hours }\end{array}$ & No \\
\hline
\end{tabular}


Run 58 Summary

Run 58 was the first of two runs to (1) continue evaluation of the new decanter design and (2) test extraction performance of heated organic recirculation. The new decanter was installed before Run 56. The organics simulating radiolysis of TPB were added to the PR after feeding. Analytical results for the run are listed in Appendix $C$, Tables 58-1 to 58-5. A smaller batch was made than usual to use up all of the $w-1$ feed during runs 58 and 5 s.

550 gallons of slurry were fed to the PR containing a 310 gallon heel. The final volume of PHA was 910 gallons. The final PHA contained $148 \mathrm{mg} / \mathrm{L}$ biphenyl and $298 \mathrm{mg} / \mathrm{L}$ diphenylamine.

The following intercuptions eccurred:

1. High $P R$ temperature during middle of feed $\left(65^{\circ} \mathrm{C}\right)$. 2. One flow interruption caused by loss of flow (related to foaming).

2. One interruption at beginning of aqueous boil due to $\mathrm{N} 2$ low flow interlock.

3. One interruption 28 minutes into aqueous boil caused by a manual shutdown, since organic recirculation could not be established. Program was shutdown and resumed three days later.

Other netes:

Added TPB and KNO3 to PHT to bring feed within specifications.

The RCD was inventoried with organic by setting up flow from the OHT through the OE to the RCD.

Drummed out OE.

Replaced OE pump with OHT pump (pump failed).

Added 30 gallons of fresh benzene to OE.

Replaced OE pump with new pump (old OHT pump failed).

Emulsion noted in $O E$ 
Run 59 Summary

Run 59 was the second of two runs to (1) continue evaluation of the new decanter design with the coalescer installed, and (2) test extraction performance of heated organic recirculation. The new decanter was installed before Run 56 . The coalescer was installed before Run 59. The organics simulating radiolysis of $T P B$ were added to the PR after feeding. Analytical results for the run are listed in Appendix C, Tables 59-1 to 59-7. A smaller batch was made than usual to use up all of the $W-1$ feed during runs 58 and 59 .

555 gallons of slurry ware fed to the PR containing a 329 gallon heel. The final volume of PHA was 1042 gallons. The final PHA contained $5 \mathrm{mg} / \mathrm{L}$ biphenyl and $260 \mathrm{mg} / \mathrm{L}$ diphenylamine.

The following interruptions occurred:

1. One interruption at beginning of feed due to high $\mathrm{N}_{2} \mathrm{O}$ concentration. Reduced feed flowrate.

2. Feed stopped because of low level in PHT (150 gallons).

3. Intentionally interrupted program 28 minutes into aqueous boil to mirror shutdown of Run 58 .

4. One interruption near end of aqueous boil due to wrong value listed for cycle time (was 528 minutes, should have been 600 minutes).

\section{Other notes:}

The RCD was inventoried with organic by adding fresh benzene to the $O E$ and pumping from the $O E$ to the RCD.

Drummed out OE.

Approximately 130 gallons of water was added to PHT to flush out all remaining feed. 


\section{Run 60 Summary}

Run 60 was the first of four runs to (1) evaluate the late wash flowsheet, and (2) continue evaluation of the new decanter design (with the coalescer installed without organic recirculation). No organics simulating radiolysis of TPB were added. No sludge was added to the slurry. Analytical results for the run are listed in Appendix $C$, Tables 60-1 to $60-4$.

An estimated 760 galions of slurry were fed to the PR containing a 319 gallon heel. The final volume of PHA was 1028 gallons. The final PHA contained $2.6 \mathrm{mg} / \mathrm{L}$ biphenyl and $15.0 \mathrm{mg} / \mathrm{L}$ diphenylamine.

The following interruptions occurred:

1. Two interruptions at beginning of feed due to high flow interlock. Throttled pump discharge valve at initiation of flow to eliminate problem.

ether notes:

Foam retardant (2000 ppm surfynol@) was added to PHT after severe foaming was produced during transfer from $W-1$ to PHT. Foaming caused by leaking diaphragm in the $W-1$ pneumatic pump. This is the same pump that had been replaced during Run 56 but had inadvertently been reinstalled.

Lost approximately 45 minutes of vantage data because of computer problem.

OE agitator was locked during entire run so OE samples are not representative.

Completed OE cycle. Cleaned RCD during beginning of OE cycle with organic vapor. 


\section{Run 61 Summary}

Run 61 was the second of four runs to (1) evaluate the late wash flowsheet, and (2) continue evaluation of the new decanter design (with the coalescer installed without organic recirculation). No organics simulating radiolysis of TPB were added. No sludge was added to the slurry. Analytical results for the run are listed in Appendix C, Tables 61-1 to $61-4$.

An estimated 760 gallons of slurry were fed to the PR containing a 319 gallon heel. The final volume of PHA was 1029 gallons. The final PHA contained $1.8 \mathrm{mg} / \mathrm{L}$ biphenyl and $12.0 \mathrm{mg} / \mathrm{L}$ diphenylamine.

The following interruptions eccurred:

1. One interruption after approximately one hour of feed due to foaming. Feed flow resumed eleven hours later, due to time spent troubleshooting and adding surfynol®.

2. One steam interruption 217 minutes into aqueous boil caused by modicon computer malfunction. Program restarted 25 minutes later.

\section{Qther notes:}

Foam retardant was not added to $\mathrm{PHT}$ during transfer from $\mathrm{W}-1$ to PHT. Because of feediny problems, foam retardant $(2000$ ppm surfynol(8) was added to the PHT after feed began.

Added approximately 40 gallons of water to PHT during feed troubleshooting.

OE agitator was locked during entire rur so OE samples are not representative.

Incomplete $O E$ cycle because of instrument problems. Cleaned RCD during beginning of $O E$ cycle with organic vapor. The $O E$ cycle aqueous boil lasted for approximately 30 minutes. 
Run 62 Summary

Run 62 was the third of four runs to (1) evaluate the late wash flowsheet, and (2) continue evaluation of the original decanter design without organic recirculation. $2000 \mathrm{mg} / \mathrm{L}$ biphenyl (simulating radiolysis of TPB) was added. No sludge was added to the slurry. Analytical results for the run are listed in Appendix C, Tables 62-1 to 62-4.

An estimated 751 gallons of slurry were fed to the PR containing a 321 gallon heel. The final volume of PHA was 1024 gallons. The final PHA contained $8.3 \mathrm{mg} / \mathrm{L}$ biphenyl and $41.1 \mathrm{mg} / \mathrm{L}$ diphenylamine.

The following interruptions occurred:

1. One interruption approximately one hour into aqueous boil caused by PR high pressure alarm. Program restarted immediately.

other notes:

Foam retardant was added to $\mathrm{PHT}$ during transfer from $\mathrm{W}-1$ to PHT (2000 ppm surfynol(B).

OE agitator was locked during entire run so OE samples are not representative.

PR pump was not started until midpoint of five hour hold. Samples prior to this are not representative.

Completed $O E$ cycle. Cleaned RCD during beginning of OE cycle with organic vapor. The $O E$ agitator was noted locked out during $O E$ cycle, unlocked, and startec

An additional five hours of aqueous boil was initiated two days later to ensure that PHA high boiling organic content was low enough. 


\section{Run 63 Summary}

Run 63 was the fourth of four runs to (1) evaluate the late wash flowsheet, and (2) continue evaluation of the original decanter design without organic recirculation. $2000 \mathrm{mg} / \mathrm{L}$ biphenyl (simulating radiolysis of TPB) was added. No sludge was added to the slurry. Analytical results for the run are listed in Appendix C, Tables 63-1 to 63-4.

760 gallons of slurry were fed to the PR containing a 323 gallon heel. The final volume of $P H A$ was 1034 gallons. The final PHA contained $1.8 \mathrm{mg} / \mathrm{L}$ biphenyl and $22.8 \mathrm{mg} / \mathrm{L}$ diphenylamine.

The following interruptions occurred:

1. Two interruptions at beginning of feed due to high flow interlock. Throttled pump discharge valve at initiation of flow to eliminate problem.

\section{ether notes:}

Foam retardant was added to $\mathrm{PHT}$ during transfer from $\mathrm{W}-1$ to PHT (2000 ppm surfynol(B).

No RCD levels were recorded during most of run due to TDR electrical signal problem.

Completed $O E$ cycle. Did not clean RCD during beginning of $O E$ cycle with organic vapor to allow the long term study of decanter performance. 


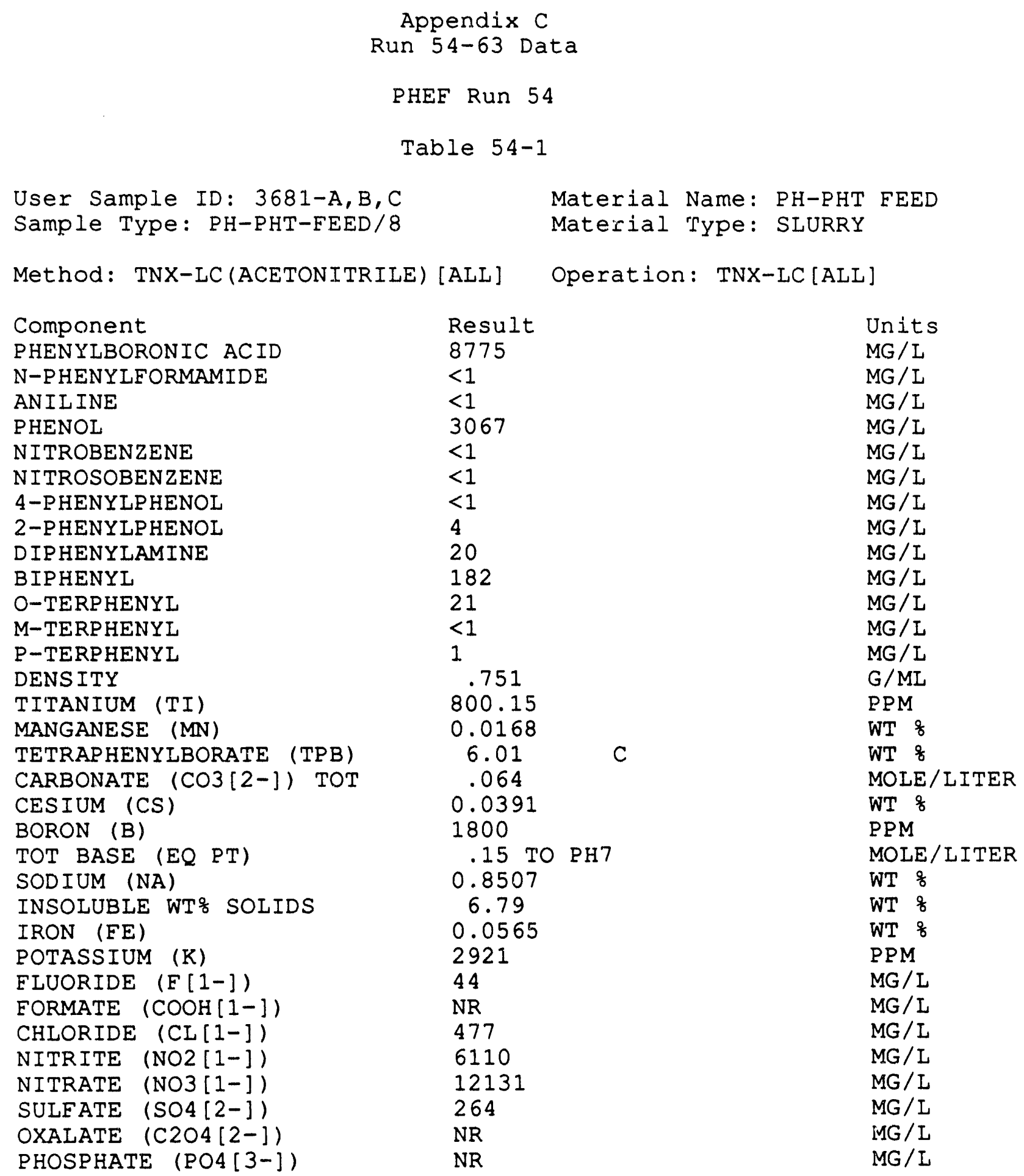


Table 54-2

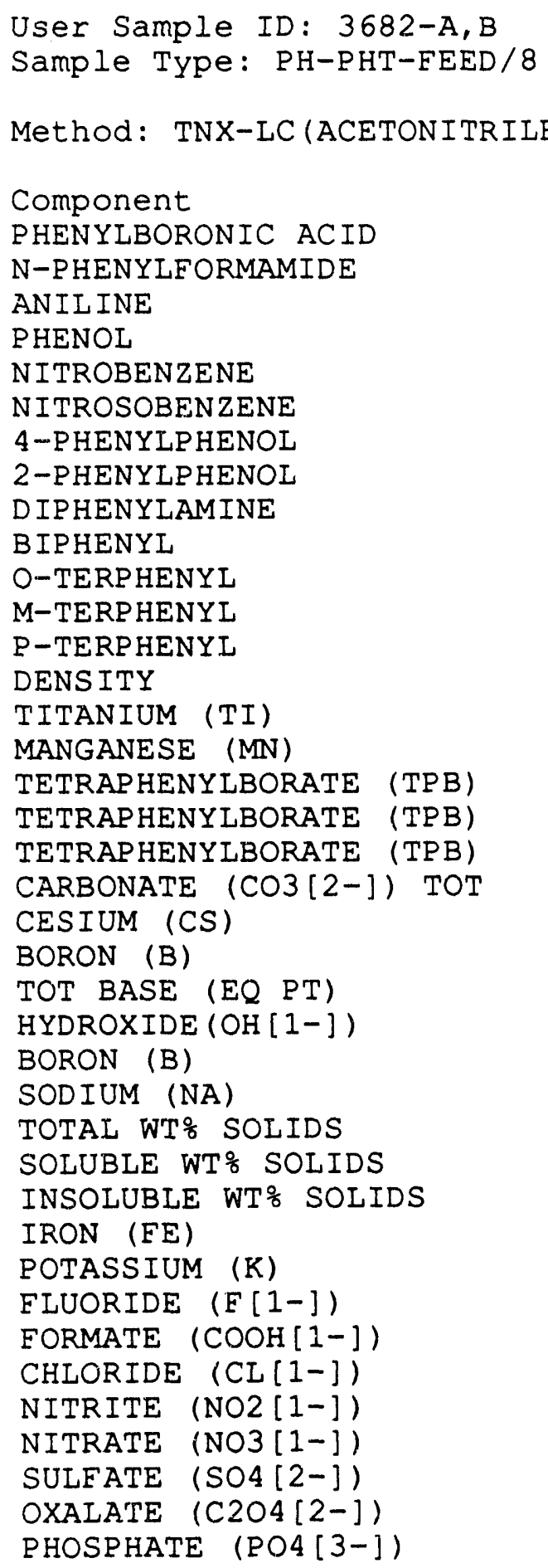

Method: TNX-LC (ACETONITRILE) [ALL] Operation: TNX-LC [ALL]
Material Name: PH-PHT FEED Material Type: SIURRY

Result

7826

$<1$

$<1$

3184

$<1$

$<1$

$<1$

725

$<1$

120

2

NOT APPLICABLE

NOT APPLICABLE

.93

943.31

0.0142

5.13

5.85

5.16

.108

0.0369

1745

.17 TO PH7

.18 TO PH7

0.3051

0.8242

11.70

3.78

7.92

0.0492

2961

47

NR

517

8779

12784

288

NR

NR
Units

$M G / L$

$M G / L$

$M G / L$

$M G / I$

$\mathrm{MG} / \mathrm{L}$

$M G / I$

$M G / L$

$M G / I$

$M G / L$

$M G / L$

$M G / I$

$M G / L$

$M G / L$

G/ML

PPM

WT $\frac{8}{8}$

WT $\frac{8}{8}$

WT $\frac{8}{8}$

WT $\frac{8}{8}$

MOLE/LITER

WT $\frac{8}{2}$

PPM

MOLE/LITER

MOLE/LITER

WT $\frac{\circ}{8}$

WT $\frac{\circ}{8}$

WT 8

WT $\frac{8}{8}$

WT $\frac{8}{8}$

WT $\frac{8}{8}$

PPM

MG / L

$M G / I$

MG/L

MG / L

MG/L

$M G / I$

$\mathrm{MG} / \mathrm{I}$

$M G / I$ 
Table 54-3

Run 54 Pre-rxn Heel

Sample ID: 200011723 Text:

User Sample ID: 3683-A, B

Simple Type: PH-PR-PRERXN/9

LIQUID/PARTICULATES

Method: TNX-LC (ACETONITRILE) [ALL] Operation: TNX-LC [ALL]

Units

Component

Result

PHENYLBORONIC ACID

11

N-PHENYLFORMAMIDE

9

ANILINE

PHENOL

$<1$

NITROBENZENE

NITROSOBENZENE

336

2

3

4-P HENYLPHENOL

12

2-PHENYLPHENOL

7

DIPHENYLAMINE

BIPHENYI

165

Material Name: PH-PR PRE-RXN

Material Type:

O-TERPHENYL

M-TERPHENYL

P-TERPHENYL

HYDROXYLAMINE NITRATE (HAN)

COPPER (CU)

BORON (B)

AMMONIUM (NH4 [1+])

COPPER (CU)

TOT ACID (EQ PT)

FLUORIDE (F[1-])

2

NOT APPLICABLE

NOT APPLICABLE

0.806

20

27.5

$<1$

16.4325

1.939

FORMATE (COOH[1-])

NR

CHLORIDE (CL [1-])

36816

NR

NITRITE (NO2[1-])

4766

NITRATE (NO3[1-])

SULFATE (SO4[2-])

50927

OXALATE (C2O4[2-])

NR

NR

MG / L

$\mathrm{MG} / \mathrm{L}$

$M G / L$

$M G / L$

$M G / L$

$M G / L$

$M G / L$

$\mathrm{MG} / \mathrm{L}$

$M G / L$

$M G / L$

$M G / L$

$M G / L$

$M G / L$

MOLE/LITER

WT 웅

PPM

$M G / L$

PPM

MOLE/LITER

$M G / L$

$M G / I$

$\mathrm{MG} / \mathrm{L}$

MG/L

$M G / L$

$M G / L$

MG / L

NR

MG/L 
Table 54-4

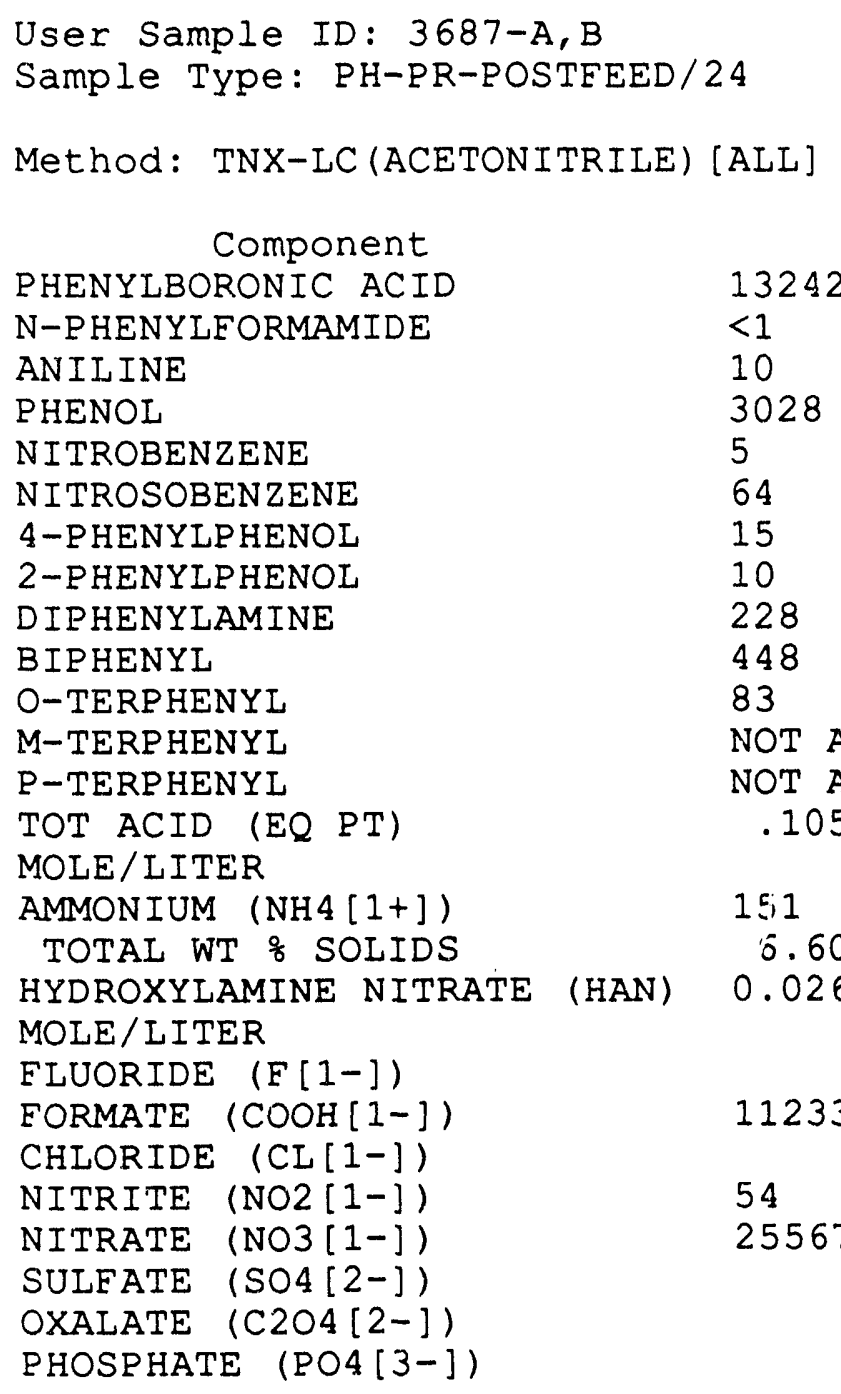

Material Name: PH-PR POST FEED Material Type: LIQUID/NO PARTICULA: Operation: TNX-LC [ALL] Result

13242

$<1$

10

3028

$$
5
$$

64

15

10

228

448

83

NOT APPLICABLE

NOT APPLICABLE .105 TO PH7

151

0.60

0.026

11233

54

25567
MG / L

$M G / L$

$\mathrm{MG} / \mathrm{L}$

$M G / L$

$M G / L$

$M G / I$

$M G / I$

$M G / L$

MG / L

$M G / L$

$M G / L$

$M G / L$

$M G / L$

MG / L WT $\frac{\circ}{8}$

MG / L

$M G / L$

$M G / L$

$M G / L$

MG/L

$M G / L$

$M G / L$

MG / L
Units 
Table 54-5

User Sample ID: $3688-A, B$

Sample Type: PH-POSTCU/25

Method: TNX-IC (FILTER) [ANI] \{MG/L\} Component

FLUORIDE (F[1-])

EORMATE (COOH[1-])

CHLORIDE (CL[1-])

NITRITE (NO2[1-])

NITRATE (NO3[1-])

SULFATE (SO4[2-])

OXALATE (C2O4[2-])

PHOSPHATE (PO4[3-])

TOT ACID (EQ PT)

COPPER (CU)

AMMONIUM (NH4[1+])

TOTAL WT $\frac{\circ}{8}$ SOLIDS

COPPER (CU)

HYDROXYLAMINE NITRATE (HAN)

42

221

469

6.50

505
Material Name: PH-PR AFTER CU

Material Type: LIQUID/PARTICULATES

Operation: TNX-IC [ANI] (MG/L)

Result

17876

23224

.069 TO PH7

0.017
Units

MG / L

$M G / L$

$M G / L$

$M G / L$

$M G / L$

$M G / L$

$M G / L$

$M G / L$

MOLE/LITER

PPM

MG / L

WT $\frac{\circ}{8}$

WT $\frac{8}{8}$

MOLE/LITER 
Table 54-6

User Sample ID: $3783-A, B, C$ Sample Type: PH-PR-POSTRXN/10

Method: TNX-LC (ACETONITRILE) [ALL] Component

PHENYLBORONIC ACID N-P HENYLFORMAMIDE

ANILINE

PHENOL

NITROBENZENE

NITROSOBENZENE

4-PHENYLPHENOL

2-PHENYLPHENOL

DIPHENYLAMINE

BIPHENYL

O-TERPHENYL

M-TERP HENYI

P-TERPHENYL

FLUORIDE (F[1-])

FORMATE (COOH[1-])

CHLORIDE (CL[1-])

NITRITE (NO2 [1-])

NITRATE (NO3[1-])

SULFATE (SO4[2-])

OXALATE (C2O4[2-])

PHOSPHATE (PO4[3-])

TOT ACID (EQ PT)

HYDROXYLAMINE NITRATE (HAN)

COPPER (CU)

SODIUM (NA)

TOTAL WT $\frac{\circ}{\circ}$ SOLIDS

IRON (FE)

CESIUM (CS)

BORON (B)

MANGANESE (MN)

TITANIUM (TI)

POTASSIUM (K)

AMMONIUM (NH4[1+])

COPPER (CU)

TOTAL ORGANIC CARBON

$\mathrm{PH}$

$<1$

117

147

2612

14

66

372

$<1$

1424

320

159

NR

NR

$<1$

254

NR

NR

377

908

244
Material Name: PH-PR POST-RXN

Material Type: LIQUID/NO PARTICULA?

Operation: TNX-LC [ALL]

Result

NOT APPLICABLE

NOT APPLICABLE

13393

2.9090

0.059 TO PH 7

$<0.0001$

.0701

8018

8.88

0.0610

2678

0.0136

462.6

$<0.01$

8687

4.56
MG / L

$M G / L$

$M G / I$

$M G / L$

$M G / L$

$M G / L$

$M G / L$

MG / L

$M G / I$

$M G / L$

$M G / L$

$\mathrm{MG} / \mathrm{L}$

$\mathrm{MG} / \mathrm{L}$

$M G / L$

$M G / L$

$M G / L$

$M G / L$

$M G / L$

$M G / L$

$M G / L$

$M G / I$

MOLE/LITER

MOLE/LITER

WT $\frac{\circ}{6}$

PPM

WT $\frac{\circ}{8}$

WT $\frac{8}{8}$

WT $\frac{\circ}{2}$

PPM

WT $\frac{8}{8}$

PPM

PPM

$M G / L$

PPM

PPM

$\mathrm{PH}$
Units

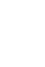

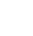

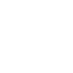


Table 55-1

User Sample ID: 3793-A,B

Sample Type: PH-PHT-PREP/26

Method: TNX-LC (FILTER) [ALL]

Component

PHENYLBORONIC ACID

N-PHENYLFORMAMIDE

ANIIINE

PHENOL

NITROBENZENE

NITROSOBENZENE

4-PHENYLP HENOL

2-PHENYLPHENOL

DIPHENYLAMINE

BIPHENYL

O-TERPHENYL

M-TERPHENYL

P-TERPHENYL

NITRITE (NO2 [1-])

MANGANESE (MN)

TETRAPHENYLBORATE (TPB)

TOTAL WT\% SOLIDS

SOLUBLE WT

INSOLUBLE WT용 SOLIDS

IRON (FE)

TITANIUM (TI)
Material Name: PH-PHT-PREP

Material Type: SLURRY

Operation: TNX-LC [ALL]

Result

7816

$<1$

$<1$

3375

$<1$

$<1$

$<1$

$<1$

$<1$

307

2

NOT APPLICABLE

NOT APPLICABLE

7320

0.0067

8.09

14.10

7.54

6.56

0.0221

677.3
MG/L

$M G / L$

$M G / L$

$M G / L$

$M G / L$

$M G / I$

$M G / L$

$M G / I$

$M G / L$

$M G / L$

$M G / L$

$M G / I$

$M G / L$

$M G / I$

WT $\frac{8}{8}$

WT $\frac{8}{8}$

WT $\frac{8}{8}$

WT $\frac{8}{8}$

WT $\frac{8}{8}$

WT 8

PPM 
Tajle 55-2

Sample ID: 200011980 Text:

$\begin{array}{ll}\text { User Sample ID: } 3794-A, B \quad \text { (RUSH!) } & \text { Material. Name: PH-PR PRE-RXN } \\ \text { Sample Type: PH-PR-PRERXN/9 } & \text { Material Type: }\end{array}$

LIQUID/PARTICULATES

Result )

Method: TNX-LC (ACETONITRILE) [ALL] Operation: TNX-IC [ALL]

Component

PHEN $\angle B O R O N I C$ ACID

N-PHEIVYLFORMAMIDE

ANIL INE

PHENOL

NITROBENZENE

NITROSOBENZENE

4-PHENYIPHENOL

2-PHENYLPHENOL

DIPHENYLAMINE

BIPHENYL

O-TERPHENYL

M-TERP HENYI

P-TERP HENYI

CESIUM (CS)

HYDROXYLAMINE NITRATE (HAN)

COPPER (CU)

BORON (B)

AMMONIUM (NH4[1+])

COPPER (CU)

TOT ACID (EQ PT)

FLUORIDE (F[1-])

FORMATE (COOH[1-])

CHLORIDE (CL $[1-])$

NITRITE (NO2[1-])

NITRATE (NO3[1-])

SULFATE (SO4[2-])

OXALATE (C2O4[2-])

PHOSPHATE (PO4 [3-])
Result

$<1$

64

$<1$

2005

12

28

69

160

2246

1710

50

2

10

11.2

0.602

100.02

3598

92

1.92

NR

46924

NR

1714

40814

NR

NR

NR

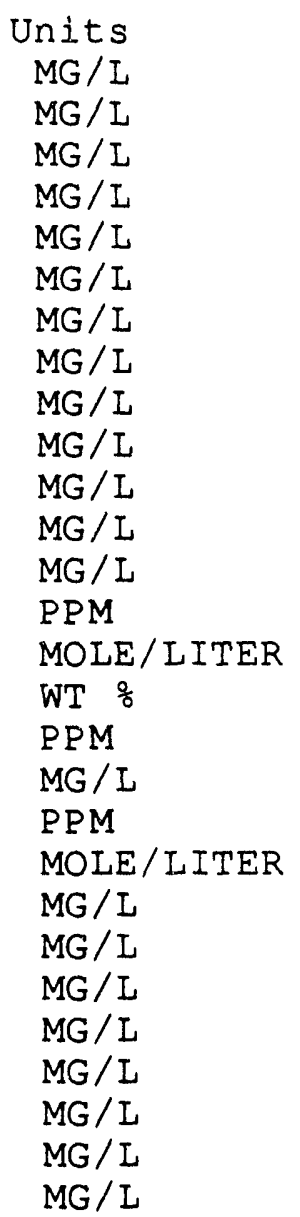


Table 55-3

User Sample ID: 3799-A, B

Sample Type: PH-PR-POSTFEED/24

Method: TNX-LC (ACETONITRILE) [ALL]

Component

PHENYLBORONIC ACID

N-PHENYLFORMAMIDE

ANIL INE

PHENOL

NITROBENZENE

NITROSOBENZENE

4-PHENYLPHENOL

2-PHENYLPHENOL

DIPHENYLAMINE

BIPHENYL

O-TERPHENYL

M-TERPHENYL

P-TERPHENYL

TOT ACID (EQ PT)

AMMONIUM (NH4[1+])

TOTAL WT $\%$ SOLIDS

HYDROXYLAMINE NITRATE (HAN)

DILUTION

FLUORIDE (E[1-])

FORMATE (COOH[1-])

CHLORIDE (CL $[1-])$

NITRITE (NO2[1-])

NITRATE (NO3 [1-])

SULFATE (SO4[2-])

OXALATE (C2O4[2-])

PHOSPHATE (PO4[3-])

$<1$

$<1$

3364

10

175

32

58

528

784

44

62

40

97

6.23

$1 / 10$

66

21123
Material Name: PH-PR POST FEED

Material Type: LIQUID/NO PARTICULA:

Operation: TNX-LC [ALL]

Result

13245

0.031 TO $\mathrm{PH} 7$

0.020

13956

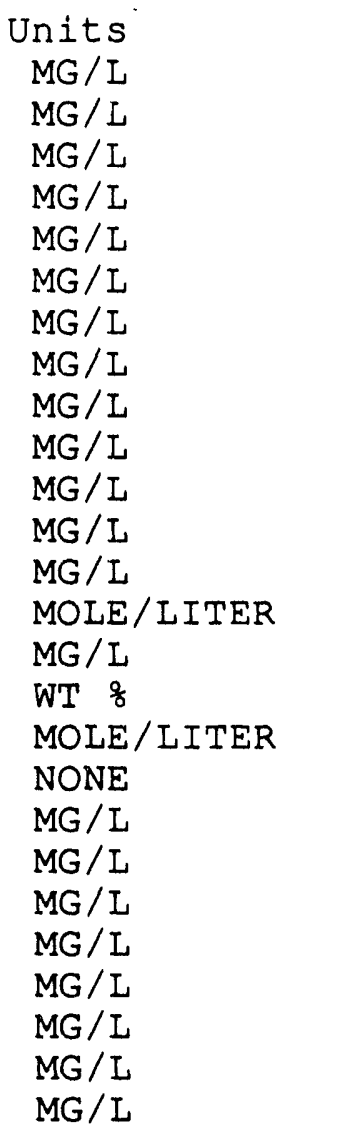


Table 55-4

User Sample ID: 3800-A, B Sample Type: PH-POSTCU/25

Method: TNX-IC (FILTER) [ANI] \{MG/L\}

Component

FLUORIDE (F[1-])

FORMATE (COOH[1-])

CHLORIDE (CL[1-])

NITRITE (NO2[1-])

NITRATE (NO3[1-])

SULFATE (SO4[2-])

OXALATE (C2O4[2-])

PHOSPHATE (PO4[3-])

TOT ACID (EQ PT)

COPPER (CU)

AMMONIUM (NH4[1+])

TOTAL WT $\frac{8}{8}$ SOLIDS

COPPER (CU)

DIIUTION

NOTEBOOK

PAGE NUMBER

OVERT IME

HYDROXYLAMINE NITRATE (HAN)
Result

13576

38

20148

$1 / 5000,1 / 100$

0.21 TO PH 7

372

164

5.96

.0506

1

58131

142

0.016
Material Name: PH-PR AFTER CU

Material Type: LIQUID/PARTICULATES

Operation: TNX-IC [ANI] (MG/L)

Units

MG / I

$\mathrm{MG} / \mathrm{L}$

$M G / I$

$\mathrm{MG} / \mathrm{L}$

$\mathrm{MG} / \mathrm{L}$

$\mathrm{MG} / \mathrm{L}$

$M G / L$

$M G / L$

MOLE/LITER

PPM

MG / L

WT $\frac{8}{8}$

WT $\frac{8}{8}$

NONE

NONE

NONE

NONE

MOLE/LITER 
Table 55-5

User Sample ID: $3849-A, B, C$

Sample Type: PH-PR-POSTRXN/10

Method: TNX-LC (ACETONITRILE) [ALL] Operation: TNX-LC [ALL]

Component

PHENYLBORONIC ACID

N-PHENYLFORMAMIDE

ANILINE

PHENOL

NITROBENZENE

NITROSOBENZENE

4-PHENYIPHENOL

2-PHENYLPHENOL

DIPHENYLAMINE

BIPHENYL

O-TERPHENYL

M-TERPHENYL

P-TERPHENYL

FLUORIDE (F [1-])

FORMATE (COOH $[1-])$

CHLORIDE (CL [1-])

NITRITE (NO2 [1-])

NITRATE (NO3[1-])

SULFATE (SO4[2-])

OXALATE (C2O4[2-])

PHOSPHATE (PO4[3-])

TOT ACID (EQ PT)

HYDROXYLAMINE NITRATE (HAN)

DILUTION

NOTEBOOK

PAGE NUMBER

OVERTIME

COPPER (CU)

SODIUM (NA)

TOTAL WT $\frac{\circ}{b}$ SOLIDS

IRON (FE)

CESIUM (CS)

BORON (B)

MANGANESE (MN)

TITANIUM (TI)

POTASSIUM (K)

AMMONIUM $(\mathrm{NH} 4[1+])$

COPPER (CU)

TOTAL ORGANIC CARBON

$\mathrm{PH}$
Material Name: PH-PR POST-RXN

Material Type: LIQUID/NO PARTICULA:

Result

$<1$

590

375

2699

6

20

189

120

810

101

76

NOT APPLICABLE

NOT APPLICABLE

19597

$<1$

24342

308

0.21 TO $\mathrm{PH} 7$

0.0002

$1 / 2$

58089

32

0.0674

9142

6.91

0.0217

0.0154

2242

0.0062

175.2

3901

415

486

8780

3.66

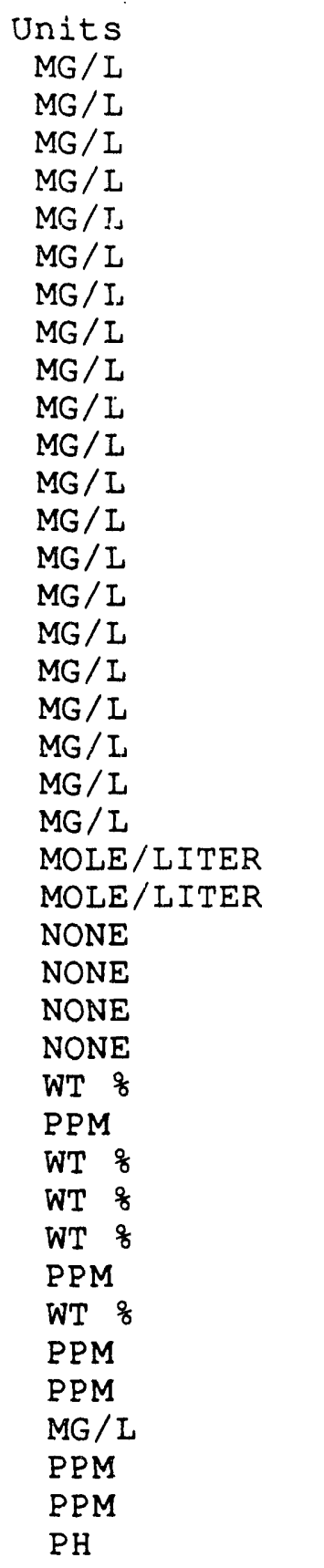


Table 56-1

User Sample ID: 3878-A, B, C Sample Type: PH-PHT-FEED $/ 8$

Method: TNX-LC (ACETONITRILE)

Component

PHENYLBORONIC ACID

N-PHENYLEORMAMIDE

ANILINE

PHENOI

NITROBENZENE

NITROSOBENZENE

4-P HENYIPHENOL

2-PHENYLPHENOL

DIPHENYLAMINE

BIPHENYL

O-TERPHENYL

M-TERPHENYL

P-TERPHENYL

FLUORIDE (F[1-])

CHLORIDE (CL[1-])

NITRITE (NO2[1-])

NITRATE (NO3[1-])

SULFATE (SO4[2-])

FLUORIDE (E[1-])

CHLORIDE (CL [1-])

NITRITE (NO2[1-])

NITRATE (NO3[1-])

SULEATE (SO4[2-])

DENSITY

TITANIUM (TI)

IRON (FE)

MANGANESE (MN)

TOTAL WT: SOLIDS

SOLUBLE WT:

INSOLUBLE WT' SOLIDS

TETRAPHENYLBORATE (TPB)

TETRAPHENYLBORATE (TPB)

CARBONATE (CO3[2-]) TOT

CARBONATE (CO3[2-]) TOT

SODIUM (NA)

DILUTION

POTASSIUM (K)

CESIUM (CS)

BORON (B)

BORON (B)

TOT BASE (EQ PT)

HYDROXIDE (OH [1-])
Material Name: PH-PHT FEED

Material Type: SLURRY

[ALL] Operation: TNX-LC [ALL]

Result

8357

$<1$

$<1$

3595

$<1$

367

$<1$

4

46

987

44

$<1$

30

52

514

7995

13330

304

52

511

7902

13223

296

.840

807.3

0.08

0.0310

14.60

7.21

7.39

7.34

7.09

.065

.047

1.0018

61

1.2761

0.0697

0.4369

2611.2

.15 TO PH7

.15 TO PH7
Units

MG / L

$M G / L$

$M G / L$

$M G / L$

$M G / L$

$M G / L$

$\mathrm{MG} / \mathrm{L}$

$M G / L$

$M G / L$

$M G / L$

$M G / L$

$M G / L$

$M G / I$

$M G / I$

$M G / L$

$\mathrm{MG} / \mathrm{L}$

$M G / I$

$M G / L$

$M G / L$

$M G / L$

$M G / L$

$M G / L$

$M G / L$

$G / M L$

PPM

WT \%

WT $\frac{8}{8}$

WT 8

WT $\frac{8}{8}$

WT 8

WT $\frac{8}{8}$

WT 8

MOLE/LITER

MOLE/LITER

WT 8

NONE

WT $\frac{8}{8}$

WT 8

WT 8

PPM

MOLE/LITER

MOLE/LITER 
Table 56-2

User Sample ID: 3874-A,B

Sample Type: PH-PR-PRERXN/ 9

Method: TNX-LC (ACETONITRILE) [ALL]

Component

PHENYIBORONIC ACID

N-PHENYLFORMAMIDE

ANILINE

PHENOL

NITROBENZENE

NITROSOBENZENE

4-PHENYLPHENOL

2-PHENYLPHENOL

DIPHENYLAMINE

BIPHENYI

O-TERPHENYL

M-TERPHENYI

P-TERPHENYL

FLUORIDE (E[1-])

FORMATE (COOH[1-])

CHLORIDE (CL $[1-])$

NITRITE (NO2 [1-])

NITRATE (NO3[1-])

SULFATE (SO4[2-])

OXALATE (C2O4[2-])

PHOSPHATE (PO4[3-])

FLUORIDE (F[1-])

FORMATE (COOH [1-])

CHLORIDE (CL[1-])

NITRITE (NO2[1-])

NITRATE (NO3[1-])

SULFATE (SO4[2-])

OXALATE (C2O4[2-])

PHOSPHATE (PO4[3-])

CESIUM (CS)

TOT ACID (EQ PT)

TOT ACID (EQ PT)

HYDROXYLAMINE NITRATE (HAN)

HYDROXYLAMINE NITRATE (HAN)

HYDROXYLAMINE NITRATE (HAN)

COPPER (CU)

COPPER (CU)

AMMONIUM (NH4 [1+])

BORON (B)
Result

$<1$

7

$<1$

86

$<1$

$<1$

32

43

318

220

18

23

3

39210

2191

51954

40561

2036

52524

\section{2}

1.68 TO PH7

1.67 TO PH7

0.744

0.759

0.746

22.3

0.0154

72.4
Material Name: PH-PR PRE-RXN

Material Type: LIQUID/PARTICULATES

Operation: TNX-LC [ALL]

Units

MG / I

MG / I

$M G / I$

$M G / L$

$M G / L$

$M G / I$

$M G / L$

$M G / I$

$M G / L$

$M G / I$

$M G / I$

$M G / I$

$M G / L$

$\mathrm{MG} / \mathrm{L}$

$M G / L$

$M G / I$

$\mathrm{MG} / \mathrm{L}$

$M G / L$

$M G / L$

$\mathrm{MG} / \mathrm{L}$

$M G / L$

$M G / L$

$M G / I$

$M G / L$

$M G / L$

$\mathrm{MG} / \mathrm{L}$

$M G / L$

$M G / L$

$M G / L$

PPM

MOLE/LITER

MOLE/LITER

MOLE/LITER

MOLE/LITER

MOLE/LITER

PPM

WT $\frac{8}{8}$

MG / L

PPM 
Table 56-3

User Sample ID: 3881-A, B

Sample Type: PH-PR-POSTFEED/24

Method: TNX-LC (ACETONITRILE) [ALL]

Component

PHENYLBORONIC ACID

N-PHENYLFORMAMIDE

ANILINE

PHENOL

NITROBENZENE

NITROSOBENZENE

4-PHENYLPHENOL

2-P HENYLP HENOL

DIPHENYLAMINE

BIPHENYL

O-TERPHENYL

M-TERPHENYL

P-TERP HENYL

FLUORIDE (F[1-])

FORMATE (COOH [1-])

CHLORIDE (CL[1-])

NITRITE (NO2 [1-])

NITRATE (NO3[1-])

SULFATE (SO4[2-])

OXALATE (C2O4[2-])

PHOSPHATE (PO4 [3-])

TOT ACID (EQ PT)

HYDROXYLAMINE NITRATE (HAN)

HYDROXYLAMINE NITRATE (HAN)

AMMONIUM (NH4[1+])

TOTAL WT $\frac{\circ}{8}$ SOLIDS
Result

9626

$<1$

$<1$

2887

$<1$

13

7

7

24

82

1

1

$<1$

11663

83

23666

.15 TO PH7

0.026

0.025

69

6.72
Material Name: PH-PR POST EEED

Material Type: LIQUID/NO PARTICULA:

Operation: TNX-LC [ALL]

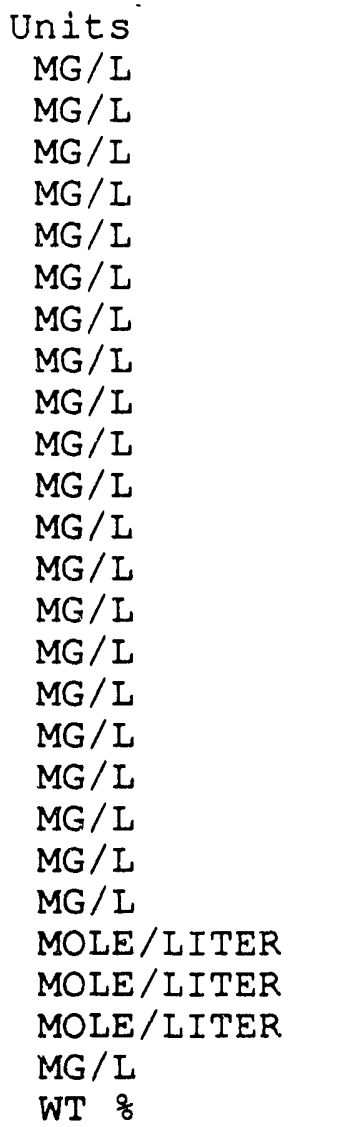


Table 56-4

User Sample ID: $3882-\mathrm{A}, \mathrm{B}, \mathrm{C}$ Sample Type: PH-POSTCU/25

Method: TNX-IC (FILTER) [ANI] $\{M G / L\}$ Component

FLUORIDE (E[1-])

FORMATE (COOH[1-])

CHLORIDE (CL $[1-])$

NITRITE (NO2 [1-])

NITRATE (NO3 [1-])

SULFATE (SO4[2-])

OXALATE (C2O4[2-])

PHOSPHATE (PO4[3-])

TOT ACID (EQ PT)

HYDROXYLAMINE NITRATE (HAN)

COPPER (CU)

COPPER (CU)

AMMONIUM (NH4[1+])

TOTAL WT $\frac{\circ}{8}$ SOLIDS

43

364

0.04

209

6.87
Material Name: PH-PR AFTER CU

Material Type: LIQUID/PARTICULATES

Operation: TNX-IC [ANI] $\{M G / L\}$

Result

13320

22239

.13 TO PH7

.0218
MG / I

$M G / L$

$M G / I$

$M G / L$

MG / L

MG / L

$M G / L$

MG / L

MOLE/LITER

MOLE/LITER

PPM

WT $\frac{\text { 웅 }}{2}$

MG / L

WT $\frac{\circ}{8}$ 
Table 56-5

User Sample ID: 3954-A, B, C Sample Type: PH-PR-POSTRXN/10

Method: TNX-LC (ACETONITRILE) [ALL]

Component

PHENYLBORONIC ACID

N-PHENYLFORMAMIDE

ANIL INE

PHENOL

NITROBENZENE

NITROSOBENZENE

4-PHENYLPHENOL

2-PHENYLPHENOL

DIPHENYLAMINE

BIPHENYL

O-TERPHENYL

M-TERPHENYL

P-TERPHENYI

FLUORIDE (F[1-])

FORMATE (COOH[1-])

CHLORIDE (CL $[1-])$

NITRITE (NO2 [1-])

NITRATE (NO3[1-])

SULFATE (SO4[2-])

OXALATE (C2O4[2-])

PHOSPHATE (PO4[3-])

$\mathrm{PH}$

TOT ACID (EQ PT)

TOTAL ORGANIC CARBON

HYDROXYLAMINE NITRATE

HYDROXYLAMINE NITRATE

COPPER ' (CU)

COPPER (CU)

AMMONIUM (NH4[1+])

SODIUM (NA)

POTASSIUM (K)

TOTAL WT $\%$ SOLIDS

TITANIUM (TI)

IRON (EE)

MANGANESE (MN)

CESIUM (CS)

BORON (B)

Result
$<1$

236

226

2494

4

49

212

85

747

144

106

21

40

13835

$<1$

26534

263

4.21

.098 TO PH7

8042

$<0.0001$

$<0.0001$

248

0.06

1301

6895

.15

7.49

423.2

0.0442

0.0175

0.0384

4433.9
Material Name: PH-PR POST-RXN

Material Type: LIQUID/NO PARTICULA'

Operation: TNX-LC [ALL]
Units
$M G / L$
$M G / L$
$\mathrm{MG} / \mathrm{L}$
$M G / L$
$M G / L$
$M G / L$
$\mathrm{MG} / \mathrm{L}$
$M G / L$
$M G / L$
$M G / L$
$M G / L$
$M G / L$
$M G / L$
$M G / L$
$M G / L$
$M G / I$
$M G / I$
$M G / L$
$M G / L$
$M G / L$
$M G / L$
$\mathrm{PH}$
MOLE/LITER
PPM
MOLE/LITER
MOLE/LITER
PPM
WT 8
MG / L
PPM
PPM
WT 옹
PPM
WT $\frac{\circ}{8}$
WT $\frac{8}{8}$
WT $\frac{8}{8}$
PPM 
Table 57-1

User Sample ID: 3976-A, B, C Sample Type: PH-PHT-FEED $/ 8$

Method: TNX-LC (ACETONITRILE) [A

Component

PHENYLBORONIC ACID

N-PHENYLFORMAMIDE

ANII INE

PHENOL

NITROBENZENE

NITROSOBENZENE

4-PHENYLPHENOL

2-PHENYLPHENOL

DIPHENYLAMINE

BIPHENYL

O-TERPHENYL

M-TERPHENYL

P-TERPHENYI

FLUORIDE (F[1-])

CHLORIDE (CL[1-])

NITRITE (NO2[1-])

NITRATE (NO3[1-])

SULFATE (SO4[2-])

FLUORIDE (F[1-])

CHLORIDE (CL [1-])

NITRITE (NO2[1-])

NITRATE (NO3[1-])

SULFATE (SO4[2-])

DENSITY

TITANIUM (TI)

IRON (FE)

MANGANESE (MN)

TOTAL WT웅 SOLIDS

SOLUBLE WT $\%$ SOLIDS

INSOLUBLE WT\% SOLIDS

TETRAPHENYLBORATE (TPB)

TETRAPHENYLBORATE (TPB)

TETRAPHENYLBORATE (TPB)

TETRAPHENYLBORATE (TPB)

TETRAPHENYLBORATE (TPB)

CARBONATE (CO3[2-])

CARBONATE (CO3[2-])

SODIUM (NA)

POTASSIUM (K)

CESIUM (CS)

BORON (B)

BORON (B)

TOT BASE (PH7)

TOT BASE (PH7)

HYDROXIDE (OH [1-])

HYDROXIDE (OH [1-])
Material Name: PH-PHT FEED

Material Type: SLURRY

Operation: TNX-LC [ALL]

Result

6928

$<1$

$<1$

3506

4

$<1$

$<1$

193

35

198

2

2

2

59

535

7502

12740

294

57

539

7633

12876

299

0.776

683.0

0.0400

0.0266

14.95

6.87

8.08

6.08

6.23

6.54

6.31

5.93

0.041

0.050

0.9897

0.9627

0.0417

0.3979

1434

0.14 TO $\mathrm{PH} 7$

0.13 TO $\mathrm{PH} 7$

0.23 TO PH 7

0.23
Units

MG / L

$M G / I$

$M G / L$

$M G / L$

$M G / L$

$M G / L$

$M G / I$

$M G / L$

$M G / L$

$M G / L$

$M G / L$

$M G / L$

$M G / L$

$M G / L$

$M G / L$

$M G / L$

$M G / L$

$M G / L$

$M G / L$

$M G / L$

$M G / L$

$M G / L$

$M G / L$

G/ML

PPM

WT $\frac{}{8}$

WT $\frac{\circ}{8}$

WT $\frac{8}{8}$

WT $\frac{8}{8}$

WT $\frac{8}{8}$

WT $\frac{8}{8}$

WT $\frac{8}{8}$

WT $\frac{8}{8}$

WT $\frac{8}{8}$

WT $\frac{8}{8}$

MOLE/LITER

MOLE/LITER

WT $\frac{9}{\circ}$

WT $\frac{8}{8}$

WT $\frac{8}{8}$

WT $\frac{\circ}{0}$

PPM

MOLE/LITER

MOLE/LITER

MOLE/LITER

MOLE/LITER 

J. T. CARTER
PAGE 59
WSRC-RP - $92-996$

Table 57-2

User Sample ID: 3982-A, B

Sample Type: PH-PR-PRERXN/ 9

Method: TNX-LC (ACETONITRILE) [ALL]

Component

PHENYLBORONIC ACID

N-PHENYLFORMAMIDE

ANILINE

PHENOL

NITROBENZENE

NITROSOBENZENE

4-PHENYLPHENOL

2-PHENYLPHENOL

DIPHENYLAMINE

BIPHENYL

O-TERPHENYL

M-TERPHENYL

P-TERPHENYI

FLUORIDE (F[1-])

FORMATE (COOH[1-])

CHLORIDE (CL [1-])

NITRITE (NO2[1-])

NITRATE (NO3[1-])

SULFATE (SO4[2-])

OXALATE (C2O4[2-])

PHOSPHATE (PO4[3-])

FLUORIDE (F[1-])

FORMATE (COOH [1-])

CHLORIDE (CL[1-])

NITRITE (NO2[1-])

NITRATE (NO3[1-])

SULFATE (SO4[2-])

OXALATE (C2O4[2-])

PHOSPHATE (PO4[3-])

CESIUM (CS)

TOT ACID (EQ PT)

TOT ACID (EQ PT)

HYDROXYLAMINE NITRATE (HAN)

HYDROXYLAMINE NITRATE (HAN)

HYDROXYLAMINE NITRATE (HAN)

COPPER (CU)

COPPER (CU)

AMMONIUM (NH4[1+])

BORON (B)

Result

4

73

13

1484

$<1$

$<1$

46

17

76

205

13

17

15

1775

1992

20.4

.664

.645

.682

59

$<1$

92
Material Name: PH-PR PRE-RXN

Material Type: LIQUID/PARTICULATES

Operation: TNX-LC [ALL]

41449

46100

41711

46561

1.66 TO PH7

1.66 TO PH7

0.0053
Units

MG / L

$\mathrm{MG} / \mathrm{L}$

$M G / L$

$M G / L$

$M G / L$

$M G / L$

$\mathrm{MG} / \mathrm{L}$

$M G / L$

$M G / L$

$\mathrm{MG} / \mathrm{L}$

$M G / L$

$M G / L$

$M G / I$

$M G / I$

$M G / L$

$M G / L$

$M G / L$

$M G / L$

$M G / L$

$M G / L$

$M G / I$

$M G / I$

$\mathrm{MG} / \mathrm{L}$

$M G / L$

$M G / I$

$M G / L$

$M G / L$

$M G / L$

MG / L

PPM

MOLE/LITER

MOLE/LITER

MOLE/LITER

MOLE/LITER

MOLE/LITER

PPM

WT $\frac{8}{8}$

MG/L

PPM 
Table 57-3

User Sample ID: 3983-A, B

Material Name: PH-PR POST FEED

Sample Type: PH-PR-POSTFEED/24

Material Type: LIQUID/NO PARTICULA?

Method: TNX-LC (ACETONITRILE) [ALL] Operation: TNX-LC [ALL]

Component

PHENYLBORONIC ACID

N-P HENYLFORMAMIDE

ANILINE

PHENOL

NITROBENZENE

NITROSOBENZENE

4-PHENYLPHENOL

2-PHENYLPHENOL

DIPHENYLAMINE

BIP HENYL

O-TERPHENYI

M-TERPHENYL

P-TERPHENYL

FLUORIDE (F[1-])

FORMATE (COOH[1-])

CHLORIDE (CL[1-])

NITRITE (NO2[1-])

NITRATE (NO3[1-])

SULFATE (SO4[2-])

OXALATE (C2O4[2-])

PHOSPHATE (PO4[3-])

TOT ACID (EQ PT)

HYDROXYLAMINE NITRATE (HAN)

AMMONIUM (NH4[1+])

TOTAL WT $\frac{\circ}{3}$ SOLIDS

\section{Result}

10835

$<1$

$<1$

3543

3

118

64

50

92

220

12

17

16

11039

35

19909

.12 TO PH7

0.025

266

6.73
Units

MG / L

$M G / L$

$M G / I$

$M G / L$

$M G / L$

$M G / L$

$M G / L$

$M G / L$

$M G / L$

$M G / L$

$M G / L$

$\mathrm{MG} / \mathrm{L}$

$M G / L$

$M G / L$

$M G / I$

$M G / L$

$M G / L$

$M G / I$

$M G / L$

$M G / L$

$M G / L$

MOLE/LITER

MOLE/LITER

$M G / L$

WT $\frac{\circ}{8}$ 
Table 57-4

User Sample ID: 3984-A, B

Sample Type: PH-PR-GENERAL/50

Method: TNX-LC (ACETONITRILE) [ALL]

Component

PHENYIBORONIC ACID

N-PHENYLFORMAMIDE

ANILINE

PHENOL

NITROBENZENE

NITROSOBENZENE

4-PHENYLPHENOL

2-PHENYLPHENOL

DIPHENYLAMINE

BIPHENYL

D-TERPHENYL

M-TERPHENYL

P-TERPHENYL

ELUORIDE (F[1-])

FORMATE (COOH[1-])

CHLORIDE (CL[1-])

NITRITE (NO2[1-])

NITRATE (NO3 [1-])

SULFATE (SO4[2-])

OXALATE (C2O4[2-])

PHOSPHATE (PO4[3-])

$\mathrm{PH}$

TOT ACID (EQ PT)

TOTAL ORGANIC CARBON

HYDROXYLAMINE NITRATE (HAN)

COPPER (CU)

COPPER (CU)

AMMONIUM (NH4[1+])

TITANIUM (TI)
Result

13171

$<1$

13

3521

152

287

212

134

593

112.0

59

16

64

10681

81

18506

199

4.17

$.10 \mathrm{TO} \mathrm{PH} 7$

13930

.021

341

0.0309

191

351.89
Material Name: PH-SAMPLE

Material Type: LIQUID/PARTICULATES

Operation: TNX-JCC [ALL]

Units

$M G / L$

$M G / L$

$M G / L$

MG / I

$M G / L$

$M G / L$

$M G / L$

$M G / I$

$M G / L$

$M G / L$

$M G / L$

$M G / L$

$M G / L$

$M G / L$

$M G / L$

MG / L

MG / L

MG/L

MG/L

MG/L

$M G / L$

$\mathrm{PH}$

MOLE/LITER

PPM

MOLE/LITER

PPM

WT $\frac{\circ}{6}$

MG / L

PPM 
Table 58-1

User Sample ID: 4563-A, B, C Sample Type: PH-PHT-FEED $/ 8$

Method: TNX-LC (ACETONITRILE) [

Component

PHENYLBORONIC ACID

N-PHENYLFORMAMIDE

ANILINE

PHENOI

NITROBENZENE

NITROSOBENZENE

4-PHENYLPHENOI

2-P HENYLPHENOL

DIPHENYLAMINE

BIPHENYL

O-TERPHENYL

M-TERP HENYL

P-TERPHENYL

FLUORIDE (F[1-])

CHLORIDE (CL [1-])

NITRITE (NO2 [1-])

NITRATE (NO3 [1-])

SULFATE (SO4[2-])

FLUORIDE (F[1-])

CHLORIDE (CL [1-])

NITRITE (NO2[1-])

NITRATE (NO3 [1-])

SULFATE (SO4 $[2-1)$

DENSITY

TITANIUM (TI)

IRON (EE)

MANGANESE (MN)

TOTAL WTO SOLIDS

SOLUBLE WT $\%$ SOLIDS

INSOLUBLE WT $\%$ SOLIDS

TETRAPHENYLBORATE (TPB)

TETRAPHENYLBORATE (TPB)

CARBONATE (CO3[2-])

CARBONATE (CO3[2-])

CARBONATE (CO3[2-])

CARBONATE (CO3[2-])

SODIUM (NA)

POTASSIUM (K)

CESIUM (CS)

BORON (B)

BORON (B)

TOT BASE (PH7)

TOT BASE (PH7)

TOT BASE (PH7)

TOT BASE (PH7)

TOT BASE ( $\mathrm{PH} 7$ )
Material Name: PH-PHT FEED

Material Type: SLURRY

Operation: TNX-LC [ALL]

Result

2926

$<1$

$<1$

2183

$<1$

$<1$

$<1$

3

109

345

$<1$

$<1$

$<1$

73

203

8044

8808

5566

63

220

8208

8995

529

.75

548.25

0.0512

0.0199

10.78

4.16

6.62

5.94

5.91

(T) .029

(T) .052

(F) .017

(F) .009

0.9582

0.6302

0.0143

5.9279

2055

.12 TO PH7

.12 TO PH7

.11 TO PH7

.11 TO PH7

.11 TO PH7
Units

MG / L

$M G / L$

$M G / L$

$M G / L$

$M G / L$

$\mathrm{MG} / \mathrm{L}$

MG/L

MG/L

$M G / L$

$M G / L$

MG / L

MG/L

$M G / I$

MG/L

MG/L

$M G / I$

$M G / L$

$M G / L$

$M G / I$

$M G / I$

$M G / L$

$M G / L$

$M G / L$

$\mathrm{G} / \mathrm{ML}$

PPM

WT $\frac{8}{8}$

WT $\frac{8}{8}$

WT $\frac{8}{8}$

WT $\frac{8}{8}$

WT 8

WT $\frac{\circ}{8}$

WT $\frac{8}{8}$

MOLE/LITER

MOLE/LITER

MOLE/LITER

MOLE/LITER

WT $\frac{8}{8}$

WT $\frac{8}{\circ}$

WT 8

WT 8

PPM

MOLE/LITER

MOLE/LITER

MOLE/LITER

MOLE/LITER

MOLE/LITER 
Table 58-2

User Sample ID: 4564-A, B

Sample Type: PH-PR-PRERXN/ 9

Method: TNX-LC (ACETONITRILE)

Component

PHENYLBORONIC ACID

N-P HENYLFORMAMIDE

ANILINE

PHENOI

NITROBENZENE

NITROSOBENZENE

4-PHENYLPHENOL

2-PHENYLPHENOL

D IPHENYLAMINE

BIPHENYL

O-TERPHENYL

M-TERP HENYL

P-TERP HENYL

FLUORIDE (F[1-])

FORMATE (COOH[1-])

CHLORIDE (CL[1-])

NITRITE (NO2[1-])

NITRATE (NO3[1-])

SULFATE (SO4[2-])

OXALATE (C2O4[2-])

PHOSPHATE (PO4[3-])

FLUORIDE (F[1-])

FORMATE (COOH[1-])

CHLORIDE (CL[1-])

NITRITE (NO2[1-])

NITRATE (NO3 [1-])

SULFATE (SO4[2-])

OXALATE (C2O4[2-])

PHOSPHATE (PO4[3-])

CESIUM (CS)

TOT ACID (EQ PT)

TOT ACID (EQ PT)

HYDROXYLAMINE NITRATE (HAN)

DILUTION

HYDROXYLAMINE NITRATE (HAN)

COPPER (CU)

COFPER (CU)

AMMONIUM (NH4 $[1+])$

BORON (B)
Material Name: PH-PR PRE-RXN

Material Type: LIQUID/PARTICULATES

Operation: TNX-LC [ALL]

Result

6

$<1$

144

$<1$

29

12

54

232

12

32

14

32158

2075

42884

31599

1984

43796

13

1.31 TO $\mathrm{PH} 7$

1.31 TO $\mathrm{PH} 7$

0.649

$.025 / 10$

0.655

111

0.0131

72

857

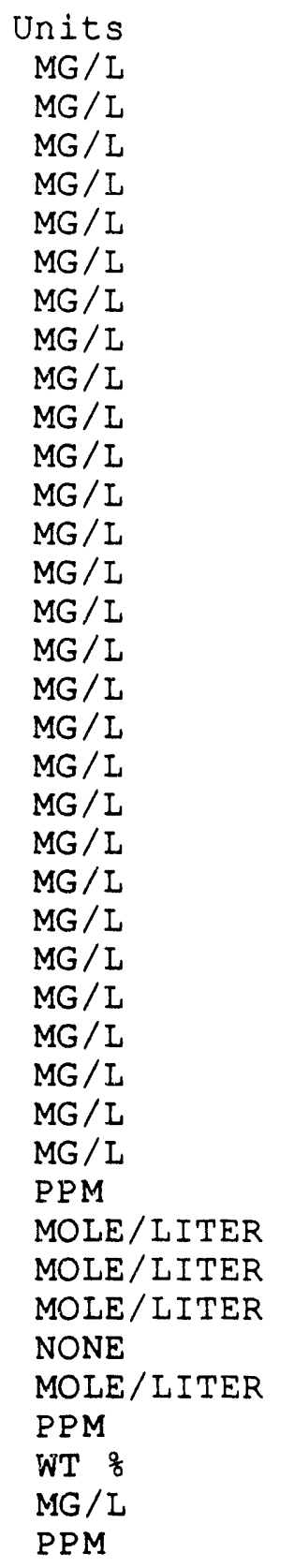


J. T. CARTER PAGE 64 WSRC-RP-92-996

Table $58-3$

User Sample ID: 4568

Sample Type: PH-PR-POSTFEED/24

Method: TNX-LC (ACETONITRILE)

Component

PHENYLBORONIC ACID

N-PHENYLFORMAMIDE

ANIIINE

PHENOL

NITROBENZENE

NITROSOBENZENE

4-PHENYLPHENOL

2-PHENYLPHENOL

DIPHENYLAMINE

BIPHENYL

O-TERPHENYL

M-TERPHENYL

P-TERPHENYL

ELUORIDE (E[1-])

FORMATE (COOH[1-])

CHLORIDE (CL $[1-])$

NITRITE (NO2[1-])

NITRATE (NO3[1-])

SULFATE (SO4[2-])

OXALATE (C2O4[2-])

PHOSPHATE (PO4[3-])

TOT ACID (EQ PT)

HYDROXYLAMINE NITRATE (HAN)

HYDROXYLAMINE NITRATE (HAN)

AMMONIUM (NH4[1+])

TOTAL WT $\frac{\circ}{\partial}$ SOLIDS

8
Material Name: PH-PR POST FEED

Material Type: LIQUID/NO PARTICULA'

Operation: TNX-LC [ALL]

Result

14353

$<1$

2064

18

13

9

69

146

$<1$

$<1$

$<1$

9081

68

18540

.12 TO PH7

0.0231

0.0230

226

5.26
Units

MG / L

$\mathrm{MG} / \mathrm{L}$

$M G / L$

$M G / L$

$M G / L$

$\mathrm{MG} / \mathrm{L}$

$\mathrm{MG} / \mathrm{L}$

MG / L

$M G / L$

MG/L

$M G / L$

$M G / L$

$\mathrm{MG} / \mathrm{L}$

$M G / L$

MG/L

MG/L

MG / L

MG / I

$M G / L$

$M G / L$

$M G / I$

MOLE/LITER

MOLE/LITER MOLE/LITER

MG/L

WT 웅 

J. T. CARTER
PAGE 65
พSRC-RP - 92-996

Table 58-4

User Sample ID: 4569

Sample Type: PH-PR-GENERAL/50

Method: TNX-LC (ACETONITRILE) [ALL]

Component

PHENYLBORONIC ACID

N-PHENYLFORMAMIDE

ANIIINE

PHENOL

NITROBENZENE

NITROSOBENZENE

4-PHENYLPHENOL

2-PHENYLPHENOL

DIPHENYLAMINE

BIPHENYL

O-TERPHENYL

M-TERPHENYL

P-TERPHENYL

FLUORIDE (F[1-])

FORMATE (COOH [1-])

CHLORIDE (CL[1-])

NITRITE (NO2[1-])

NITRATE (NO3[1-])

SULFATE (SO4[2-])

OXALATE (C2O4[2-])

PHOSPHATE (PO4[3-])

$\mathrm{PH}$

AMMONIUM (NH4[1+])

TITANIUM (TI)
Result

12082

$<1$

48

2067

$44^{<1}$

8

9

132

191

7

10

10

9834

68

19249

123

4.03

479

206.05
Material Name: PH-SAMPLE

Material Type: LIQUID/PARTICULATES

Operation: TNX-LC [ALL]

Units

$M G / L$

$M G / L$

$M G / L$

$M G / L$

$M G / L$

$M G / L$

$M G / L$

$M G / L$

$M G / L$

$M G / L$

$M G / I$

$M G / L$

$M G / L$

$M G / L$

$M G / L$

$\mathrm{MG} / \mathrm{L}$

MG/L

MG / L

$M G / I$

$M G / L$

MG/L

$\mathrm{PH}$

MG / L

PPM 
Table 58-5

User Sample ID: 4780

Sample Type: PH-PR-POSTRXN/10

Method: TNX-LC (ACETONITRILE) [ALL]

Component

PHENYLBORONIC ACID

N-PHENYLFORMAMIDE

ANIL INE

PHENOL

NITROBENZENE

NITROSOBENZENE

4-PHENYLPHENOL

DIPHENYLAMINE

BIPHENYL

O-TERPHENYL

M-TERPHENYL

P-TERPHENYI

FLUORIDE (F[1-])

FORMATE (COOH[1-])

CHLORIDE (CL [1-])

NITRITE (NO2[1-])

NITRATE (NO3[1-])

SULFATE (SO4[2-])

OXALATE (C2O4[2-])

PHOSPHATE (PO4[3-])

$\mathrm{PH}$

TOT ACID (EQ PT)

MOLE/LITER

TOTAL ORGANIC CARBON

HYDROXYLAMINE NITRATE (HAN)

MOLE/LITER

HYDROXYLAMINE NITRATE (HAN)

MOLE/LITE

DILUTION

NOTEBOOK

PAGE NUMBER

OVERT IME

COPPER (CU)

COPPER (CU)

SODIUM (NA)

POTASSIUM (K)

AMMONIUM (NH4[1+])

TOTAL WT $\frac{\circ}{8}$ SOLIDS

TITANIUM (TI)

IRON (EE)

MANGANESE (MN)

CESIUM (CS)

BORON (B)

307

365

1917

10

27

31

298

148

38

120

65

8675

$<1$

191

4.12

6206

$1 / 2$

40

402

7101

6572

960

5.01
Result

$<1$

19758

.089 TO PH7

Material Name: PH-PR POST-RXN

Material Type: LIQUID/NO PARTICULA!

Operation: TNX-LC [ALL]

Units

$M G / L$

$M G / L$

$M G / L$

$M G / L$

$M G / L$

$M G / L$

$M G / L$

$M G / L$

$M G / L$

$M G / I$

$M G / L$

MG / L

$M G / L$

MG/I

$\mathrm{MG} / \mathrm{L}$

$M G / L$

$\mathrm{MG} / \mathrm{L}$

$\mathrm{MG} / \mathrm{L}$

$M G / I$

$M G / L$

$\mathrm{PH}$

PPM

$<0.0002$

$<0.0002$

58089

.0473

278.38

0.0483

0.020

0.0204

1086
NONE

NONE

NO: $\mathrm{T}$

NONE:

PPM

WT 8

PPM

PPM

MG / L

WT $\frac{\circ}{8}$

PPM

WT $\frac{8}{8}$

WT $\frac{\circ}{8}$

WT 8

PPM 
Table 59-1

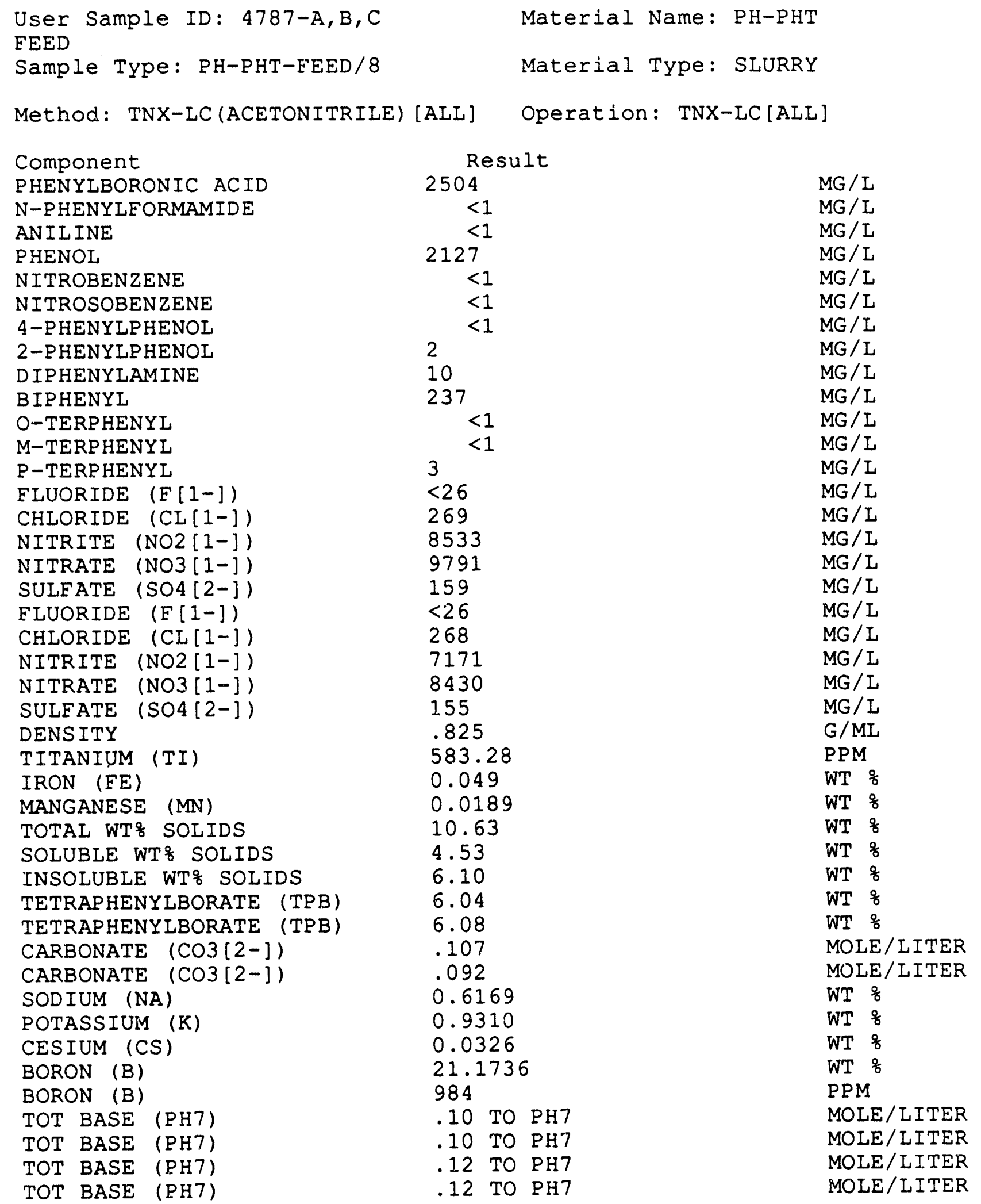


Table 59-2

User Sample ID: 5031-A,B

Sample Type: PH-PR-PRERXN/9

Method: TNX-IC (ACETONITRILE)

Component

PHENYLBORONIC ACID

N-PHENYLFORMAMIDE

ANILINE

PHENOL

NITROBENZENE

NITROSOBENZENE

4-PHENYLPHENOL

2-PHENYLPHENOL

DIPHENYLAMINE

BIPHENYI

O-TERPHENYL

M-TERPHENYL

P-TERPHENYL

FLUORIDE (E[1-])

FORMATE (COOH[1-])

CHLORIDE (CL $[1-])$

NITRITE (NO2[1-])

NITRATE (NO3[1-])

SULFATE (SO4[2-])

OXALATE (C2O4[2-])

PHOSPHATE (PO4[3-])

CESIUM (CS)

TOT ACID (EQ PT)

MOLE/LITER

TOT ACID (EQ PT)

MOLE/LITER

HYDROXYLAMINE NITRATE (HAN)

MOLE/LITER

COPPER (CU)

COPPER (CU)

AMMONIUM (NH4[1+])

BORON (B)
Material Name: PH-PR PRE-RXN

Material Type: LIQUID/PARTICULATES

[ALL] Operation: TNX-LC [ALL]

Result

29

$<1$

$<1$

209

$<1$

$<1$

10

9

75

$<1$

8

4

$<1$

25605,25817

$<201<208$

37945,37596

9.25

1.20 TO PH7

1. 17 TO $\mathrm{PH} 7$

.6255

40

0.0521

146

90.7
Units

MG/L

$M G / I$

$M G / I$

MG / L

$\mathrm{MG} / \mathrm{I}$

$M G / L$

$M G / L$

$\mathrm{MG} / \mathrm{L}$

$\mathrm{MG} / \mathrm{L}$

$\mathrm{MG} / \mathrm{L}$

$M G / L$

$M G / L$

$M G / L$

$M G / L$

$\mathrm{MG} / \mathrm{L}$

$M G / L$

$M G / L$

$M G / L$

$M G / L$

$M G / L$

MG/I

PPM

PPM

WT $\frac{8}{5}$

MG/L

PPM 
Table 59-3

User Sample ID: 4792-A, B

Sample Type: PH-PR-POSTFEED/24

Method: TNX-LC (ACETONITRILE) [ALL]

Component

PHENYLBORONIC ACID

N-P HENYLFORMAMIDE

ANILINE

PHENOL

NITROBENZENE

NITROSOBENZENE

4-PHENYLPHENOL

2-PHENYLPHENOL

DIP HENYLAMINE

BIPHENYL

O-TERPHENYI

M-TERPHENYL

P-TERPHENYL

FLUORIDE (F[1-])

FORMATE (COOH[1-])

CHLORIDE (CL[1-])

NITRITE (NO2[1-])

NITRATE (NO3[1-])

SULFATE (SO4[2-])

OXALATE (C2O4[2-])

PHOSPHATE (PO4[3-])

TOT ACID (EQ PT)

HYDROXYLAMINE NITRATE (HAN)

HYDROXYLAMINE NITRATE (HAN)

AMMONIUM (NH4[1+])

TOTAL WT $\frac{\circ}{2}$ SOLIDS
Result 8036

$<1$

6

1523

$<1$

8

4

4

62

40

1

3

2

8398

40

17468

.11 TO PH7

0.0137

0.0134

76

4.34
Material Name: PH-PR POST FEED

Material Type: LIQUID/NO PARTICULA?

Operation: TNX-IC [ALL]

Units

MG/L

$M G / L$

$M G / I$

$M G / L$

$M G / L$

$M G / L$

$M G / I$

$M G / I$

$M G / L$

$M G / L$

$M G / L$

$M G / L$

$M G / L$

$M G / L$

$M G / I$

$M G / L$

$M G / L$

$M G / I$

MG/I

$M G / L$

$M G / L$

MOLE/LITER

MOLE/IITER

MOLE/LITER

MG / L

WT 8 
Table 59-4

User Sample ID: 4793-A, B, C

Sample. Type: PH-PR-GENERAL/50

Method: TNX-LC (ACETONITRILE) [ALL]

Component

PHENYLBORONIC ACID

N-P HENYLFORMAMIDE

ANIL INE

PHENOL

NITROBENZENE

NITROSOBENZENE

4-P HENYIPHENOL

2-PHENYLPHENOL

DIPHENYLAMINE

BIPHENYL

O-TERPHENYL

M-TERPHENYL

P-TERPHENYL

FLUORIDE (F[1-])

FORMATE (COOH[1-])

CHLORIDE (CL[1-])

NITRITE (NO2[1-])

NITRATE (NO3 [1-])

SULFATE (SO4[2-])

OXALATE (C2O4[2-])

PHOSPHATE (PO4[3-])

$\mathrm{PH}$

TOT ACID (EQ PT)

TOTAL ORGANIC CARBON

HYDROXYLAMINE NITRATE (HAN)

COPPER (CU)

COPPER (CU)

AMMONIUM (NH4[1+])

TITANIUM (TI)

Result

8192

$<1$

16

1478

5

4

22

16

35

111

1

6

3

8820

$<22$

16411

180

3.84

7897

382

150
Material Name: PH-SAMPLE

Material Type: LIQUID/PARTICULATES

Operation: TNX-LC [ALL]

.11 TO PH7

0.0063

0.0931

228.95
Units

MG / L

$M G / L$

$M G / L$

$M G / L$

$M G / L$

$M G / L$

$M G / I$

$M G / L$

$M G / L$

$M G / L$

$\mathrm{MG} / \mathrm{L}$

$M G / L$

$\mathrm{MG} / \mathrm{L}$

$M G / L$

$\mathrm{MG} / \mathrm{L}$

$M G / L$

$M G / I$

$\mathrm{MG} / \mathrm{L}$

$M G / L$

$M G / L$

$M G / L$

$\mathrm{PH}$

MOLE/LITER

PPM

MOLE/IITER

PPM

WT $\frac{8}{8}$

MG/L

PPM 
Table 59-5

User Sample ID: 5017

Sample Type: PH-PR-POSTRXN/10

Method: TNX-LC (ACETONITRILE)

Component

PHENYLBORONIC ACID

N-PHENYLFORMAMIDE

ANILINE

PHENOL

NITROBENZENE

NITROSOBENZENE

4-PHENYLPHENOL

2-PHENYLPHENOL

DIPHENYLAMINE

BIPHENYL

O-TERPHENYL

M-TERPHENYL

P-TERPHENYL

FORMATE (COOH [1-])

NITRITE (NO2[1-])

NITRATE (NO3[1-])

SULFATE (SO4[2-])

$\mathrm{PH}$

TOT ACID (EQ PT)

TOTAL ORGANIC CARBON

HYDROXYLAMINE NITRATE (HAN)

HYDROXYLAMINE NITRATE (HAN)

COPPER (CU)

COPPER (CU)

AMMONIUM (NH4[1+])

SODIUM (NA)

DILUTION

NOTEBOOK

PAGE NUMBER

OVERTIME

POTASSIUM (K)

TOTAL WT $\frac{z}{8}$ SOLIDS

TITANIUM (TI)

IRON (FE)

MANGANESE (MN)

CESIUM (CS)

BORON (B)
Material Name: PH-PR POST-RXN

Material Type: LIQUID/NO PARTICULA

[ALL] Operation: TNX-LC [ALL]

Result

179

332

1456

$<1$

38

9

31

251

6

24

82

34

8511

7

17541

100

3.96

.071 TO PH7

5326

$<0.0001$

$<0.0001$

362

0.0474

717

5336

5001

9123

55

5343

4.61

261.46

0.0522

0.0194

0.0163

2484
Units

MG / L

$M G / L$

$M G / L$

$\mathrm{MG} / \mathrm{L}$

$M G / L$

$\mathrm{MG} / \mathrm{L}$

$M G / L$

$M G / L$

$\mathrm{MG} / \mathrm{L}$

$M G / L$

$M G / L$

$M G / L$

$M G / L$

$\mathrm{MG} / \mathrm{I}$

$\mathrm{MG} / \mathrm{L}$

$M G / L$

$M G / L$

$\mathrm{PH}$

MOLE/LITER

PPM

MOLE/LITER

MOLE/LITER

PPM

WT $\frac{\circ}{5}$

MG / L

PPM

NON

NON

NON

NON

PPM

WT $\%$

PPM

WT $\frac{\circ}{8}$

WT $\frac{8}{8}$

WT $\frac{8}{8}$

PPM 
Table 59-6

User Sample ID: 5018

Sample Type: PH-PR-POSTRXN/10

Method: TNX-LC (ACETONITRILE) [ALL] Component PHENYLBORONIC ACID N-PHENYLFORMAMIDE ANIL INE PHENOL NITROBENZENE NITROSOBENZENE 4-PHENYLPHENOL 2-PHENYLPHENOL DIPHENYLAMINE BIPHENYI O-TERPHENYI M-TERPHENYL P-TERPHENYL FLUORIDE (F[1-])

FORMATE (COOH [1-])

CHLORIDE (CL[1-])

NITRITE (NO2[1-])

NITRATE (NO3[1-])

SULFATE (SO4[2-])

OXALATE (C2O4[2-])

PHOSPHATE (PO4[3-])

$\mathrm{PH}$

TOT ACID (EQ PT)

TOTAL ORGANIC CARBON

HYDROXYLAMINE NITRATE (HAN)

COPPER, (CU)

COPPER (CU)

AMMONIUM (NH4 $[1+])$

SODIUM (NA)

POTASSIUM (K)

TOTAL WT $\%$ SOLIDS

TITANIUM (TI)

IRON (FE)

MANGANESE (MN)

CESIUM (CS)

BORON (B)

$$
191
$$

328

1540

7

96

32

270

4

27

96

48

7542

$<1$

104

4.15

303

727
Material Name: PH-PR POST-RXN

Material Type: LIQUID/NO PARTICULA:

Operation: TNX-LC [ALL]

Result

$<1$

15624

0.083

5184

.0002

0.0513

5061

5583

4.53

284.60

0.0492

0.0199

0.0160

2361
Units

MG / L

$M G / L$

$M G / L$

MG / L

MG / I

$M G / L$

$M G / L$

$M G / I$

MG/L

$\because G / L$

$\mathrm{MG} / \mathrm{L}$

$M G, ' L$

$M G / L$

$M G / L$

$\mathrm{MG} / \mathrm{I}$

$M G / L$

$M G / L$

$M G / L$

$M G / L$

$M G / L$

$M G / I$

$\mathrm{PH}$

MOLE/LITER

PPM

MOLE/LITER

PPM

WT $\frac{\circ}{5}$

MG / L

PPM

PPM

WT 8

PIM

WT $\frac{8}{8}$

WT $\frac{8}{8}$

WT $\frac{8}{8}$

PPM 


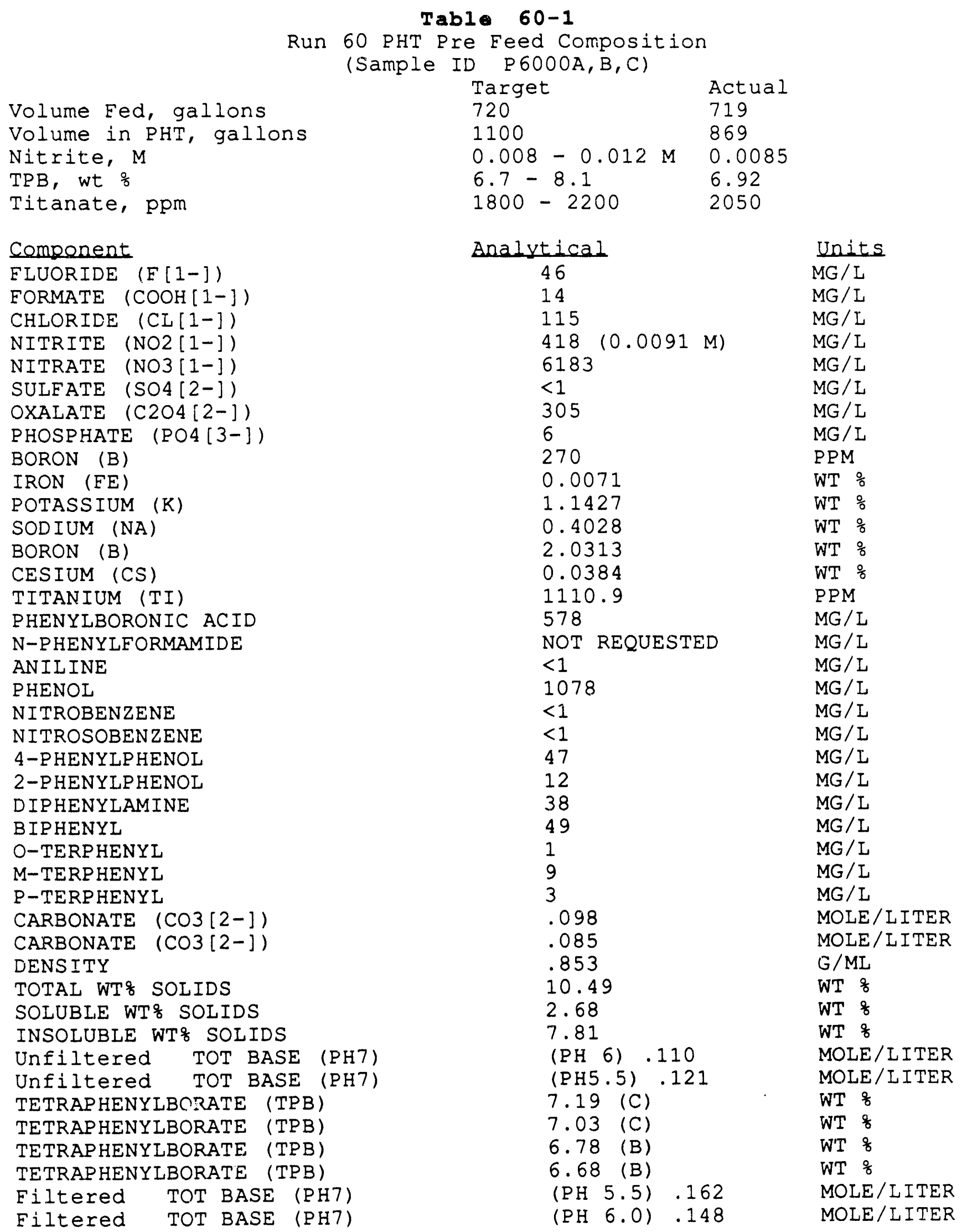


Table 60-2

Run 60 PHT Post Feed Composition (Sample ID P6126A, B, C)

PHENYLBORONIC ACID

N-PHENYLFORMAMIDE

ANILINE

PHENOL

NITROBENZENE

NITROSOBENZENE

4-P HENYLPHENOL

2-PHENYLPHENOL

DIPHENYLAMINE

BIPHENYL

O-TERPHENYL

M-TERPHENYL

P-TERP HENYL

TITANIUM (TI)

IRON (FE)

MANGANESE (MN)

TOTAL WTO SOLIDS

FILTERED WEIGHT

FILTERED DRY WEIGHT

SOLUBLE WT응 SOLIDS

INSOLUBLE WT응 SOLIDS

TETRAPHENYLBORATE (TPB)

TETRAPHENYLBORATE (TPB)
571

1146

$<1$

$<1$

19

9

12

3

$<1$

12

$<1$

1217.6

0.0105

.0007

11.84

4.0686

.1072

2. 64

9.20

7.64

7.34
MG/L

$\mathrm{MG} / \mathrm{L}$

$M G / L$

$M G / L$

$M G / L$

$M G / L$

$M G / L$

$M G / I$

$M G / L$

$M G / L$

$M G / L$

$M G / L$

$M G / L$

PPM

WT $\frac{8}{8}$

WT 음

WT 웋

G

G

WT \%

WT $\frac{\circ}{8}$

WT $\frac{8}{8}$

WT $\frac{\circ}{\partial}$ 
Table 60-3

PRE-REACTION HEEL COMPOSITION

(Sample ID P6001A, B)

Volume of heel, Gallons

Formic acid, M

Copper, ppm

component Analytical

PHENYLBORONIC ACID

N-PHENYLFORMAMIDE

ANILINE

PHENOL

NITROBENZENE

NITROSOBENZENE

4-PHENYLPHENOL

2-PHENYLPHENOL

DIPHENYLAMINE

BIPHENYL

O-TERPHENYL

M-TERPHENYL

P-TERPHENYL

FLUORIDE (F[1-])

FORMATE (COOH [1-])

CHLORIDE (CL[1-])

NITRITE (NO2[1-])

NITRATE (NO3[1-])

SULFATE (SO4[2-])

OXALATE (C2O4[2-])

PHOSPHATE (PO4[3-])

CESIUM (CS)

TOT ACID (EQ PT)

MOLE/LITER

COPPER (CU)

COPPER (CU)

BORON (B)

AMMONIUM (NH4[1+])
Target

320

$1.49-1.79 \mathrm{M}$

$2295-3520$

\section{Target}

\begin{tabular}{|c|c|c|c|}
\hline & & & \\
\hline$<1$ & & & $\mathrm{MG} / \mathrm{L}$ \\
\hline$<1$ & & & MG / L \\
\hline$<1$ & & & $M G / L$ \\
\hline 28 & & & MG / L \\
\hline$<1$ & & & $M G / I$ \\
\hline$<1$ & & & $\mathrm{MG} / \mathrm{L}$ \\
\hline 11 & & & $\mathrm{MG} / \mathrm{I}$ \\
\hline 14 & & & $\mathrm{MG} / \mathrm{L}$ \\
\hline 160 & & & $\mathrm{MG} / \mathrm{I}$ \\
\hline 4 & & & MG / L \\
\hline$<1$ & & & $\mathrm{MG} / \mathrm{L}$ \\
\hline$<1$ & & & $\mathrm{MG} / \mathrm{I}$ \\
\hline$<1$ & & & $\mathrm{MG} / \mathrm{L}$ \\
\hline$<7$ & & & $\mathrm{MG} / \mathrm{L}$ \\
\hline 73721 & & & $\mathrm{MG} / \mathrm{L}$ \\
\hline$<20$ & & & $\mathrm{MG} / \mathrm{L}$ \\
\hline$<1$ & & & $M G / L$ \\
\hline 161 & & & $\mathrm{MG} / \mathrm{L}$ \\
\hline$<27$ & & & $\mathrm{MG} / \mathrm{L}$ \\
\hline$<19$ & & & $M G / L$ \\
\hline$<1$ & & & $\mathrm{MG} / \mathrm{L}$ \\
\hline 1.70 & & & PPM \\
\hline & 1.70 & TO & $\mathrm{PH} 7$ \\
\hline $\begin{array}{l}2921 \\
0.2807 \\
38.1 \\
<1\end{array}$ & & & $\begin{array}{l}\text { PPM } \\
\text { WT \% } \\
\text { PPM } \\
\text { MG/L }\end{array}$ \\
\hline
\end{tabular}

Actual

319

1.64

2921
MG / L 
Table 60-4

Aqueous Product Analyses

Sample ID P6122A,B,C

Compenent

TOTAL ORGANIC CARBON

Soluble COPPER (CU)

Total COPPER (CU)

AMMONIUM (NH4[1+])

SODIUM (NA)

POTASSIUM (K)

TOTAL WT $\frac{\circ}{6}$ SOLIDS

TITANIUM (TI)

IRON (EE)

MANGANESE (MN)

CESIUM (CS)

BORON (B)

FORMATE

Total Acid

TAC (TOC-Formate)

TAC (From LC Analysis)
Analytical

9019

597

0.0840

$<1$

0.4948

5287

4.91

684.54

0.0035

.0002

0.1140

2851

22,247

0.22

PPM

PPM

WT $\frac{\circ}{6}$

MG / L

PPM

PPM

WT $\frac{\circ}{0}$

PPM

WT $\frac{\circ}{0}$

WT $\frac{0}{8}$

WT $\frac{8}{3}$

PPM

PPM

$M$

3079

1297
PPM

PPM

\begin{tabular}{|l|l|r|r|r|r|}
\hline Component & Units & $\begin{array}{l}\text { P6122A } \\
\text { Average of } \\
\text { 3 Analyses }\end{array}$ & $\begin{array}{l}\text { P6122B } \\
\text { Average of } \\
\text { 3 Analyses }\end{array}$ & Average & $\begin{array}{l}\text { standard } \\
\text { deviation }\end{array}$ \\
\hline PHENYLBORONIC ACID & MG/L & 9.00 & 7.00 & 8.00 & 1.67 \\
N-PHENYLFORMAMIDE & MG/L & 262.33 & 210.00 & 236.17 & 40.98 \\
ANILINE & MG/L & 157.67 & 113.67 & 135.67 & 28.81 \\
PHENOL & MG/L & 1.755 .33 & $1,496.00$ & $1,625.67$ & 241.59 \\
NITROBENZENE & MG/L & 1.00 & 1.00 & 1.00 & 0.00 \\
NITROSOBENZENE & MG/L & 1.00 & 1.00 & 1.00 & 0.00 \\
4-PHENYLPHENOL & MG/L & 3.33 & 4.33 & 3.83 & 1.72 \\
2-PHENYLPHENOL & MG/L & 1.00 & 1.67 & 1.33 & 0.52 \\
DIPHENYLAMINE & MG/L & 13.00 & 17.00 & 15.00 & 3.22 \\
BIPHENYL & MG/L & 2.33 & 2.33 & 2.33 & 1.21 \\
O-iERP HENYL & MG/L & 1.00 & 2.00 & 1.50 & 0.84 \\
M-TERP HENYL & MG/L & 1.00 & 1.33 & 1.17 & 0.41 \\
P-TERPHENYL & MG/L & 1.00 & 1.67 & 1.33 & 0.52 \\
\hline
\end{tabular}


Table 61-1

User Sample ID: 6143-A, B, C Sample Type: PH-PHT-EEED/8

Method: TNX-LC (ACETONITRILE)

Component

PHENYLBORONIC ACID

N-PHENYLFORMAMIDE

AN IL INE

PHENOL

NITROBENZENE

NITROSOBENZENE

4-PHENYLPHENOL

2-PHENYIPHENOL

DIPHENYLAMINE

BIPHENYL

O-TERP HENYL

M-TERPHENYL

P-TERPHENYL

FLUORIDE (F[1-])

FORMATE ( $\mathrm{COOH}[1-])$

CHLORIDE (CL $[1-])$

NITRITE (NO2[1-])

NITRATE (NO3[1-])

SULFATE (SO4[2-])

OXALATE (C2O4[2-])

PHOSPHATE (PO4[3-])

FLUORIDE (F[1-])

FORMATE (COOH[1-])

CHLORIDE (CL[1-])

NITRITE (NO2[1-])

NITRATE (NO3[1-])

SULFATE (SO4[2-])

OXALATE (C2O4[2-])

PHOSPHATE (PO4 [3-])

DENSITY

TITANIUM (TI)

IRON (FE)

MANGANESE (MN)

TOTAL WT\% SOLIDS

SOLUBLE WT욤 SOLIDS

INSOLUBLE WT\% SOLIDS

TETRAPHENYLBORATE (TPB)

TETRAP HENYLBORATE (TPB)

CARBONATE (CO3[2-])

CARBONATE (CO3[2-])

SODIUM (NA)

POTASSIUM (K)

CESIUM (CS)

BORON (B)

BORON (B)

TOT BASE (PH5.0)
Material Name: PH-PHT FEED

Material Type: SLURRY

[ALL] $\{$ Operation: TNX-LC [ALL] $\{M G / L\}$

Result

562

Units

MG / L

$M G / L$

$M G / L$

$M G / L$

$M G / L$

$M G / I$

$M G / L$

$M G / L$

$M G / L$

$M G / L$

$\mathrm{MG} / \mathrm{L}$

$M G / I$

$M G / L$

$M G / L$

$M G / L$

$\mathrm{MG} / \mathrm{L}$

$M G / L$

MG / L

$\mathrm{MG} / \mathrm{L}$

$\mathrm{MG} / \mathrm{L}$

$M G / L$

$M G / L$

$M G / L$

$M G / L$

$M G / L$

$M G / L$

$\mathrm{MG} / \mathrm{L}$

$M G / L$

$M G / L$

G/ML

PPM

WT $\frac{\circ}{0}$

WT $\frac{8}{8}$

WT $\frac{8}{8}$

WT $\frac{\circ}{0}$

WT $\frac{\circ}{8}$

WT $\frac{8}{8}$

WT $\frac{\circ}{8}$

MOLE/LITER

MOLE/LITER

WT $\frac{\circ}{8}$

WT $\frac{\circ}{8}$

WT $\frac{8}{8}$

WT $\frac{\circ}{6}$

PPM

MOLE/LITER 
J. T. CARTER

$\begin{array}{lll}\text { TOT } & \text { BASE } & \text { (PH5.5) } \\ \text { TOT } & \text { BASE } & (\text { PH } 6.0) \\ \text { TOT } & \text { BASE } & (\text { PH } 6.5) \\ \text { TOT } & \text { BASE } & (\text { PH } 5.0) \\ \text { TOT } & \text { BASE } & (\text { PH5.5) } \\ \text { TOT } & \text { BASE } & (\text { PH5.0) } \\ \text { TOT } & \text { BASE } & (\text { PH5.5) } \\ \text { TOT } & \text { BASE } & (\text { PH } 6.0) \\ \text { TOT } & \text { BASE } & (\text { PH } 6.5)\end{array}$

PAGE 78

.185

.168

.146

.197

.190

.137

.130

.117

.101
WSRC-RP-92-996

MOLE/LITER MOLE/LITER MOLE/LITER MOLE/LITER MOLE/LITER MOLE/LITER MOLE/LITER MOLE/LITER MOLE/LITER 
Table 61-2

User Sample ID: 6151-A, B

Sample Type: PH-PR-PRERXN/9

Method: TNX-LC (ACETONITRILE) [ALI] \{

Component

PHENYLBORONIC ACID

N-PHENYLFORMAMIDE

ANILINE

PHENOI

NITROBENZENE

NITROSOBENZENE

4-PHENYLPHENOL

2-PHENYLPHENOL

DIPHENYLAMINE

BIPHENYL

O-TERPHENYL

M-TERPHENYL

P-TERPHENYL

TOT ACID (EQ PT)

MOLE/LITER

COPPER (CU)

COPPER (CU)
Result

14

427

$<1$

$<1$

$<1$

$<1$

$<1$

9

$<1$

9

$<1$

$1.90 \mathrm{TO}$ PH 7

3016

3016
Material Name: $P H-P R$ PRE-RXN

Material Type: LIQUID/PARTICULATES

Operation: TNX-IC $[A L L]\{M G / L\}$

Units

MG / L

$M G / L$

MG / L

$M G / L$

MG/L

$M G / L$

MG / L

MG / L

MG / L

MG / L

MG / L

MG/L

$M G / L$

PPM

WT $\frac{8}{8}$ 
Table 61-3

User Sample ID: 6186-A, B Sample TYpe: PH-PR-POSTFEED/24

Method: TNX-LC (ACETONITRILE) [ALL]
Material Name: PH-PR POST FEED Material Type: LIQUID/NO PARTICULA:
Component

PHENYLBORONIC ACID N-PHENYLFORMAMIDE

ANILINE

PHENOL

NITROBENZENE

NITROSOBENZENE

4-PHENYLPHENOI.

2-PHENYLPHENOL

DIPHENYLAMINE

BIPHENYL

O-TERPHENYI

M-TERPHENYL

P-TERPHENYL

TOT ACID (EQ PT)

COPPER (CU)

AMMONIUM (NH4[1+])
Result 8308

154

1785

$<1$

8

15

16

89

87

2

$<1$

$<1$

.28 TO PH7

890

$<1$

Operation: TNX-LC [ALL] $\{M G / L\}$

Units

MG / I

$M G / I$

$M G / L$

$M G / L$

$M G / I$

$M G / I$

$\mathrm{MG} / \mathrm{L}$

$M G / L$

$M G / L$

$\mathrm{MG} / \mathrm{L}$

$M G / I$

$M G / L$

$M G / I$

MOLE/LITER

PPM

MG / I 
Table 61-4

User Sample ID: 6272-A, B

Sample Type: PH-PR-POSTRXN/10

Method: TNX-LC (ACETONITRILE) [ALL] \{

Component

PHENYLBORONIC ACID

N-PHENYLFORMAMIDE

ANIIINE

PHENOL

NITROBENZENE

NITROSOBENZENE

4-PHENYLPHENOL

2-PHENYLPHENOL

DIPHENYLAMINE

BIPHENYL

O-TERPHENYL

M-TERP HENYI

P-TERPHENYL

$\mathrm{PH}$

TOT ACID (EQ PT)

TOTAL ORGANIC CARBON

TOTAL ORGANIC CARBON

COPPER (CU)

COPPER (CU)

AMMONIUM (NH4[1+])

TOTAL WT $\%$ SOLIDS

TITANIUM (TI)

CESIUM (CS)

BORON (B)
Tesult

$$
<1
$$

32

122

1710

11

26

23

12

13

4

2

$<1$

8

3.67

.29 TO PH7

9780

9909

710

0.0779

$<1$

5.19

513.97

0.0254

2112.6 BY ICP
Material Name: PH-PR POST-RXN

Material Type: LIQUID/NO PARTICULA?

Operation: TNX-LC [ALL] \{MG/L\}

Units

MG / L

$M G / L$

$M G / L$

MG/L

$M G / L$

$M G / L$

MG / L

$M G / L$

$M G / I$

$M G / L$

$\mathrm{MG} / \mathrm{L}$

$M G / L$

$\mathrm{MG} / \mathrm{L}$

$\mathrm{PH}$

MOLE/LITER

PPM

PPM

PPM

WT $\frac{8}{5}$

MG / I

WT 웅

PPM

WT $\frac{8}{8}$

PPM 
Table $61-5$

User Sample ID: 6276-A, B, C Sample Type: PH-PHT-PREP/26

Method: TNX-LC (ACETONITRILE) [ALL] \{

Component

PHENYLBORONIC ACID

N-PHENYLFORMAMIDE

AN ILINE

PHENOL

NITROBENZENE

NITROSOBENZENE

4-PHENYLPHENOL

2-PHENYIPHENOI

DIPHENYLAMINE

BIPHENYL

O-TERPHENYL

M-TERPHENYL

P-TERPHENYL

TITANIUM (TI)

NITRITE (NO2[1-])

IRON (EE)

TOTAL WT웋 SOLIDS

SOLUBLE WT

INSOLUBLE WT웋 SOLIDS

TETRAPHENYLBORATE (TPB)

TETRAPHENYLBORATE (TPB)
Result

561

1138

$<1$

321

72

6

28

49

$<1$

9

1

725.23

393

11.20

2.74

8.462

7.24

7.16
Material Name: PH-PHT-PREP

Material Type: SLURRY

Operation: TNX-LC [ALL] $\{\mathrm{MG} / \mathrm{L}\}$

Units

$\mathrm{MG} / \mathrm{I}$

$\mathrm{MG} / \mathrm{I}$

$M G / I$

$M G / I$

$\mathrm{MG} / \mathrm{L}$

$M G / I$

$\mathrm{MG} / \mathrm{L}$

$\mathrm{MG} / \mathrm{I}$

$\mathrm{MG} / \mathrm{L}$

$M G / L$

$\mathrm{MG} / \mathrm{L}$

$M G / L$

MG/I

PPM

MG/L

WT 옿

WT $\frac{8}{6}$

WT 8

WT \%

WT $\frac{\circ}{6}$

WT $\frac{8}{2}$ 
Table $62-1$

User Sample ID: 6302-A, B

Sample Type: PH-PHT-FEED/8

Method: TNX-LC (ACETONITRILE) [ALL] \{

Component

PHENYLBORONIC ACID

N-PHENYLEORMAMIDE

ANILINE

PHENOL

NITROBENZENE

NITROSOBENZENE

4-PHENYLPHENOI

2-PHENYLPHENOL

DIPHENYLAMINE

BIPHENYI

O-TERPHENYI

M-TERPHENYL

P-TERPHENYI

TITANIUM (TI)

User Sample ID: 6350-A, B

Sample Type: PH-PHT-FEED/8

Method: TNX-LC (ACETONITRILE) [ALL] \{

Component

PHENYLBORONIC ACID

N-PHENYLFORMAMIDE

AN IL INE

PHENOL

NITROBENZENE

NITROSOBENZENE

4-PHENYIPHENOL

2-PHENYIPHENOL

DIPHENYLAMINE

BIPHENYL

O-TERPHENYL

M-TERPHENYL

P-TERPHENYL

DENSITY

TITANIUM (TI)

IRON (FE)

MANGANESE (MN)

SODIUM (NA)

POTASSIUM (K)
Result

1141

$1394^{<1}$

$<1$

87

22

36

11

1563

1

12

3

901.42
Result

1193

1412

$<1$

$<1$

$<1$

6

16

2212

1

7

5

.848

841.49

0.0044

0.0001

0.9745

0.5135
Material Name: PH-PHT FEED Material Type: SLURRY

Operation: TNX-LC [ALL] $\{M G / L\}$

Units

MG / L

$M G / L$

$M G / L$

$M G / L$

$M G / L$

$M G / I$

$M G / L$

$M G / L$

$M G / L$

$M G / L$

$M G / I$

$M G / I$

MG / L

PPM

Material Name: PH-PHT FEED Material Type: SLURRY

Operation: TNX-LC [ALL] $\{M G / L\}$

Units

MG / L

$M G / L$

$M G / L$

$M G / L$

$M G / L$

$M G / L$

$M G / L$

$M G / I$

$M G / L$

$M G / L$

$M G / L$

MG / L

$M G / L$

G/ML

PPM

WT 8

WT $\frac{8}{8}$

WT $\frac{8}{8}$

WT 8 
Table $62-2$

User Sample ID: 6351-A, B

Sample. Type: $P H-O E-P R E R X N-A Q / 41$

Method: TNX-LC (ACETONITRILE) [ALL] \{

Component

PHENYLBORONIC ACID

N-PHENYLEORMAMIDE

ANI L INE

PHENOI

NITROBENZENE

NITROSOBENZENE

4-PHENYLPHENOL

2-PHENYLPHENOL

DIPHENYLAMINE

BIPHENYL

O-TERPHENYI

M-TERPHENYL

P-TERPHENYL

TOTAL ORGANIC CARBON
Result

42

38

$<1$

520

8

3

22

119

35

5

$<1$

$<1$

21574
Material Name: PH-OE PRE-REACTION-i Material Type: LIQUID/NO PARTICULA:

Operation: TNX-LC [ALL] $\{M G / L\}$

Units

MG / L

$M G / L$

$M G / L$

$M G / L$

$M G / L$

$M G / L$

$M G / L$

$M G / L$

MG/L

MG / L

$M G / I$

$M G / L$

MG/L

PPM 
J. T. CARTER

PAGE 85

WSRC-RP $-92-996$

Table $62-3$

User Sample ID: 6386-A,B

Sample Type: PH-PR-POSTFEED/24

Method: TNX-LC (ACETONITRILE) [ALL] \{ Operation: TNX-LC [ALL] $\{M G / L\}$

Component

PHENYLBORONIC ACID

N-PHENYLFORMAMIDE

ANIIINE

PHENOL

NITROBENZENE

NITROSOBENZENE

4-P HENYLP HENOL

2-PHENYLPHENOL

DIPHENYLAMINE

BIPHENYL

O-TERPHENYL

M-TERPHENYL

P-TERPHENYL
Material Name: PH-PR POST FEED

Material Type: LIQUID/NO PARTICULA?

$\begin{array}{rl}\text { Value } & \text { Units } \\ 11 & \mathrm{MG} / \mathrm{L} \\ 20 & \mathrm{MG} / \mathrm{L} \\ <1 & \mathrm{MG} / \mathrm{L} \\ 473 & \mathrm{MG} / \mathrm{L} \\ <1 & \mathrm{MG} / \mathrm{L} \\ <1 & \mathrm{MG} / \mathrm{L} \\ 7 & \mathrm{MG} / \mathrm{L} \\ 5 & \mathrm{MG} / \mathrm{L} \\ 26 & \mathrm{MG} / \mathrm{L} \\ <1 & \mathrm{MG} / \mathrm{L} \\ <1 & \mathrm{MG} / \mathrm{L} \\ <1 & \mathrm{MG} / \mathrm{L} \\ <1 & \mathrm{MG} / \mathrm{L}\end{array}$


J. T. CARTER

PAGE 86

WSRC-RP - 92-996

Table $62-4$

User Sample ID: 6472-A, B

Sample Type: PH-PR-POSTRXN/10

Method: TNX-LC (ACETONITRILE) [ALL] \{ Operation: TNX-LC [ALL] \{MG/L\}
Material Name: PH-PR POST-RXN Material Type: LIQUID/NO PARTICULA: 

J. T. CARTER
BAGE 87
WSRC-RP-92-996

Table 63-1

User Sample ID: 6587-A, B

Sample Type: PH-PHT-FEED/8

Method: TNX-LC (ACETONITRILE) [ALL] \{ operation: TNX-IC [ALL] $\{M G / L\}$
Material Name: PH-PHT EEED Material Type: SLURR'

\begin{tabular}{|c|c|c|c|}
\hline Component & Value & Units & $\begin{array}{c}\# \\
\text { Analyses }\end{array}$ \\
\hline 2-P HENYLP HENOL & 284 & MG / L & \\
\hline 2-P HENYLP HENOL & 658 & MG / I & \\
\hline 2-P HENYLP HENOL & 688 & MG / L & \\
\hline 2-P HENYLP HENOL & $<1$ & $M G / L$ & 6 \\
\hline 4-P HENYLP HENOL & 4358 & $M G / L$ & \\
\hline 4-P HENYLP HENOL & $<1$ & $M G / L$ & 7 \\
\hline 4-P HENYLP HENOL & 160 & $M G / I$ & \\
\hline ANILINE & $<1$ & MG / I & 9 \\
\hline BIPHENYL & 798 & MG / L & \\
\hline BIPHENYL & 1044 & MG / L & \\
\hline BIPHENYL & 779 & $M G / L$ & \\
\hline BIPHENYL & 3925 & MG / L & \\
\hline BIPHENYL & 3955 & MG / L & \\
\hline BIPHENYI & 3856 & $M G / L$ & \\
\hline BIPHENYL & 996 & $\mathrm{MG} / \mathrm{L}$ & \\
\hline BIPHENYL & 834 & $M G / I$ & \\
\hline BIPHENYI & 1225 & MG / L & \\
\hline DENSITY & 0.84 & $\mathrm{G} / \mathrm{ML}$ & \\
\hline DENSITY & 0.825 & $\mathrm{G} / \mathrm{ML}$ & \\
\hline DENSITY & 0.856 & $\mathrm{G} / \mathrm{ML}$ & \\
\hline DENSITY & 0.884 & $G / M L$ & \\
\hline DENSITY & 0.858 & $\mathrm{G} / \mathrm{ML}$ & \\
\hline DENSITY. & 0.832 & $\mathrm{G} / \mathrm{ML}$ & \\
\hline DENSITY & 0.826 & $\mathrm{G} / \mathrm{ML}$ & \\
\hline DENSIIY & 0.838 & $\mathrm{G} / \mathrm{ML}$ & \\
\hline DENSITY & 0.775 & $\mathrm{G} / \mathrm{ML}$ & \\
\hline DIPHENYLAMINE & 4 & $M C / L$ & \\
\hline DIPHENYIAMINE & 1 & $M G$, & \\
\hline DIPHENYLAMINE & 7 & MG! & \\
\hline DIPHENYLAMINE & 8 & $M G_{i}$ & \\
\hline DIPHENYLAMINE & 3 & $M G / L$ & \\
\hline DIPHENYLAMINE & 2 & $\mathrm{MC} / \mathrm{S}$ & \\
\hline DIPHENYLAMINE & 5 & MG / I & \\
\hline DIPHENYLAMINE & 4 & MG / I & \\
\hline DIPHENYLAMINE & 3 & $\mathrm{ME} / \mathrm{L}$ & \\
\hline IRON (FE) & 0.0 .99 & HI & \\
\hline M-TERPHENYL & $<1$ & $M G / L$ & 9 \\
\hline MANGANESE (MN) & 0.000 & WT $\frac{9}{8}$ & \\
\hline NITROBENZENE & $<1$ & $M G / L$ & 8 \\
\hline NITROBENZENE & 1102 & $M G / L$ & \\
\hline NITROSOBENZENE & $<1$ & $M G / L$ & 9 \\
\hline
\end{tabular}




COMPONENT
O-TERPHENYL
O-TERPHENYL
O-TERPHENYL
O-TERPHENYI
O-TERPHENYL
O-TERPHENYL
P-TERPHENYL
PHENOL
PHENOL
PHENOL
PHENOI
PHENOL
PHENOL
PHENOL
PHENOL
PHENOL
PHENYLBORONIC ACID
PHENYLBORONIC ACID
PHENYLBORONIC ACID
PHENYIBORONIC ACID
PHENYLBORONIC ACID
PHENYLBORONIC ACID
PHENYLBORONIC ACID
PHENYLBORONIC ACID
PHENYLBORONIC ACID
POTASSIUM (K)
SODIUM (NA)

\begin{tabular}{|c|c|c|}
\hline Value & Units & $\begin{array}{c}\# \\
\text { Analyses }\end{array}$ \\
\hline$<1$ & MG / L & \\
\hline 1 & MG / L & \\
\hline 3 & $M G / L$ & \\
\hline 3 & $M G / L$ & \\
\hline 3 & $M G / L$ & \\
\hline$<1$ & $M G / L$ & 5 \\
\hline$<1$ & $M G / L$ & 9 \\
\hline 1562 & MG / L & \\
\hline 1557 & $M G / L$ & \\
\hline 1558 & MG / L & \\
\hline 1504 & MG / I & \\
\hline 1498 & $M G / L$ & \\
\hline 1562 & MG / L & \\
\hline 1562 & MG / I & \\
\hline 1562 & $M G / L$ & \\
\hline 1531 & MG / L & \\
\hline 1052 & MG / I & \\
\hline 1041 & $M G / L$ & \\
\hline 1045 & MG / L & \\
\hline 997 & $M G / L$ & \\
\hline 1049 & MG / L & \\
\hline 960 & MG / L & \\
\hline 1057 & $M G / L$ & \\
\hline 1078 & $M G / L$ & \\
\hline 1015 & $\mathrm{MG} / \mathrm{L}$ & \\
\hline 1.0184 & WT $\frac{\circ}{\partial}$ & \\
\hline 1.0117 & WT $\frac{q}{8}$ & \\
\hline
\end{tabular}


Table 63-2

User Sample ID: 6588-A, B

Sample TYPe: PH-OE-PRERXN-AQ/41

Method: TNX-LC (ACETONITRILE) [ALL] \{
Material Name: PH-OE PRE-REACTION-i Material Type: LIQUID/NO PARTICULA'

Operation: TNX-LC [ALL] $\{M G / L\}$
Component

PHENYLBORONIC ACID

N-P HENYLFORMAMIDE

ANILINE

PHENOL

NITROBENZENE

NITROSOBENZENE

4-P HENYLP HENOL

2-P HENYLP HENOL

DIPHENYLAMINE

BIPHENYL

O-TERPHENYL

M-TERP HENYL

P-TERP HENYL

$\begin{array}{rl}\text { Value } & \text { Units } \\ 27 & \mathrm{MG} / \mathrm{I} \\ 31 & \mathrm{MG} / \mathrm{I} \\ <1 & \mathrm{MG} / \mathrm{I} \\ 564 & \mathrm{MG} / \mathrm{I} \\ 29 & \mathrm{MG} / \mathrm{I} \\ 21 & \mathrm{MG} / \mathrm{I} \\ 14 & \mathrm{MG} / \mathrm{I} \\ 6 & \mathrm{MG} / \mathrm{L} \\ 5 & \mathrm{MG} / \mathrm{L} \\ 17 & \mathrm{MG} / \mathrm{I} \\ <1 & \mathrm{MG} / \mathrm{I} \\ <1 & \mathrm{MG} / \mathrm{L} \\ <1 & \mathrm{MG} / \mathrm{L}\end{array}$


Table 63-3

User Sample ID: 6623-A, B

Sample. Type: PH-PR-POSTFEED/24

Method: TNX-LC (ACETONITRILE) [ALI] \{
Material Name: PH-PR POST FEED

Material Type: LIQUID/NO PARTICULA:

Operation: TNX-IC [ALL] $\{\mathrm{MG} / \mathrm{L}\}$

\section{Component}

PHENYLBORONIC ACID

N-P HENYLFORMAMIDE

ANIIINE

PHENOL

NITROBENZENE

NITROSOBENZENE

4-P HENYLP HENOL

2-P HENYLPHENOL

DIP HENYLAMINE

BIPHENYL

O-TERPHENYI

M-TERPHENYL

P-TERPHENYL

$\begin{array}{rl}\text { Value } & \text { Units } \\ 8111 & \mathrm{MG} / \mathrm{L} \\ <1 & \mathrm{MG} / \mathrm{L} \\ 145 & \mathrm{MG} / \mathrm{L} \\ 2326 & \mathrm{MG} / \mathrm{L} \\ 17 & \mathrm{MG} / \mathrm{L} \\ <1 & \mathrm{MG} / \mathrm{L} \\ 13 & \mathrm{MG} / \mathrm{L} \\ 4 & \mathrm{MG} / \mathrm{L} \\ 104 & \mathrm{MG} / \mathrm{L} \\ 581 & \mathrm{MG} / \mathrm{L} \\ <1 & \mathrm{MG} / \mathrm{L} \\ <1 & \mathrm{MG} / \mathrm{L} \\ <1 & \mathrm{MG} / \mathrm{L}\end{array}$



J. T. CARTER
PAGE 91
WSRC-RP-92-996

Table 63-4

User Sample ID: 6709-A, B

Sample. Type: PH-PR-POSTRXN/10

Method: TNX-LC (ACETONITRILE) [ALL] \{

Component

2-PHENYIP HENOL

2-P HENYLP HENOL

2-P HENYLP HENOL

2-P HENYLP HENOL

2-PHENYLP HENOL

2-PHENYIP HENOL

2-PHENYLPHENOL

2-P HENYLP HENOL

2-P HENYLP HENOL

4-P HENYLP HENOL

4-PHENYIP HENOI

4-PHENYLP HENOL

4-P HENYLP HENOL

4-P HENYLP HENOL

4-PHENYLP HENOL

AMMONIUM (NH4 [1+])

ANILINE

ANILINE

ANIIINE

ANILINE

ANIIINE

ANIIINE

ANIIINE

ANILINE

ANIIINE

BIPHENYL

BIP HENYL

BIPHENYL

BIPHENYL

BIPHENYL

BIPHENYL

BIPHENYL

COPPER (CU)

COPPER (CU)

DIP HENYLAMINE

D IP HENYI AMINE

DIP HENYLAMINE

DIP HENYLAMINE

D IP HENYLAMINE

DIP HENYLAMINE

DIP HENYLAMINE
Value

8

3

$<1$

9

3

2

2

5

2

$<1$

11

2

7

16

8

$<1$

129

129

127

128

129

126

130

126

124

2

$<1$

3

1

3

1

1

590

592

26

23

22

19

21

24

19
Material Name: PH-PR POST-RXN

Material Type: LIQUID/NO PARTICULA:

Operation: TNX-LC $[A L L]\{M G / L\}$

$$
\begin{aligned}
& \text { Units } \\
& \text { MG/L } \\
& \text { MG/L } \\
& \text { MG/L } \\
& M G / L \\
& M G / L \\
& M G / L \\
& M G / L \\
& M G / L \\
& M G / L \\
& M G / L \\
& M G / L \\
& M G / L \\
& M G / L \\
& M G / L \\
& M G / L \\
& M G / L \\
& M G / L \\
& M G / L \\
& M G / L \\
& M G / L \\
& M G / L \\
& M G / L \\
& M G / L \\
& M G / L \\
& M G / L \\
& M G / L \\
& M G / L \\
& M G / L \\
& M G / L \\
& M G / L \\
& M G / L \\
& M G / L \\
& \text { PPM } \\
& \text { WT } \\
& M G / L \\
& M G / L \\
& M G / L \\
& M G / L \\
& M G / L \\
& M G / L \\
& M G / L
\end{aligned}
$$

Analyses

4

9

3 


\begin{tabular}{|c|c|c|c|}
\hline Componerit & Value & Units & $\begin{array}{c}\# \\
\text { Analyses }\end{array}$ \\
\hline DIPHENYLAMINE & 22 & $M G / L$ & \\
\hline DIP HENYLAMINE & 29 & MG / L & \\
\hline IRON (EE) & 0.0174 & WT $\frac{\circ}{6}$ & \\
\hline M-TERPHENYL & $<1$ & MG / L & 7 \\
\hline M-TERPHENYL & 2 & MG / L & \\
\hline M-TERPHENYL & 1 & MG / L & \\
\hline MANGANESE (MN) & 0.0006 & WT $\%$ & \\
\hline N-PHENYLFORMAMIDE & 176 & MG / L & \\
\hline N-P HENYLFORMAMIDE & 174 & $M G / L$ & \\
\hline N-P HENYLFORMAMIDE & 174 & $\mathrm{MG} / \mathrm{L}$ & \\
\hline N-P HENYLFORMAMIDE & 180 & MG / L & \\
\hline N-PHENYLFORMAMIDE & 176 & MG / I & \\
\hline N-P HENYLFORMAMIDE & 177 & MG / L & \\
\hline N-P HEN YLFORMAMIDE & 198 & $\mathrm{MG} / \mathrm{L}$ & \\
\hline N-P HENYLFORMAMIDE & 194 & MG / L & \\
\hline N-P HENYLFORMAMIDE & 192 & MG / L & \\
\hline NITRATE $\quad($ NO3 $[1-])$ & & MG / L & \\
\hline NITRITE (NO2[1-]) & & MG / L & \\
\hline NITROBENZENE & 9 & MG / L & \\
\hline NITROBENZENE & 9 & $\mathrm{MG} / \mathrm{L}$ & \\
\hline NITROBENZENE & 13 & $M G / I$ & \\
\hline NITROBENZENE & $<1$ & MG / L & 3 \\
\hline NITROBENZENE & 3 & $M G / L$ & \\
\hline NITROBENZENE & 15 & MG / L & \\
\hline NITROBENZENE & 26 & MG / L & \\
\hline NITROSCBENZENE & 28 & $\mathrm{MG} / \mathrm{I}$ & \\
\hline NITROS'JBENZENE & 12 & $M G / L$ & \\
\hline NITRC.SOBENZENE & 28 & $M G / L$ & \\
\hline NITRUSOBENZENE & 16 & $M G / L$ & \\
\hline NITROSOBENZENE & 5 & $\mathrm{MG} / \mathrm{L}$ & \\
\hline NITROSOBENZENE & 6 & MG / L & \\
\hline NITROSOBENZENE & 5 & MG/L & \\
\hline NITROSOBENZENE & 10 & $\mathrm{MG} / \mathrm{L}$ & \\
\hline NITROSOBENZENE & 14 & MG / L & \\
\hline O-TERPHENYL & 1 & $\mathrm{MG} / \mathrm{L}$ & \\
\hline O-TERPHENYI & $<1$ & $\mathrm{MG} / \mathrm{L}$ & 6 \\
\hline O-TERPHENYL & 1 & $M G / L$ & \\
\hline O-TERP HENYL & 1 & $M G / L$ & \\
\hline P-TERPHENYL & 1 & $\mathrm{MG} / \mathrm{L}$ & \\
\hline P-TERP HENYI & $<1$ & MG / L & 6 \\
\hline P-TERP HENYL & 1 & $M G / L$ & \\
\hline P-TERP HENYL & 1 & MG / L & \\
\hline $\mathrm{PH}$ & (A) 3.89 & $\mathrm{PH}$ & \\
\hline $\mathrm{PH}$ & (B) 3.90 & $\mathrm{PH}$ & \\
\hline $\mathrm{PH}$ & (C) 3.90 & $\mathrm{PH}$ & \\
\hline PHENOL & 2175 & $M G / L$ & \\
\hline PHENOL & 2160 & MG / I & \\
\hline PHENOL & 2152 & MG / L & \\
\hline
\end{tabular}


J. T. CARTER

COMPONEnt
PHENOL
COMPOnEnt
PHENOL
PHENOL
PHENOL
PHENOL
PHENOL
PHENYLBORONIC ACID
PHENYLBORONIC ACID
PHENYLBORONIC ACID
PHENYLBORONIC ACID
PHENYLBORONIC ACID
PHENYLBORONIC ACID
PHENYLBORONIC ACID
PHENYLBORONIC ACID
PHENYLBORONIC ACID
POTASSIUM (K)
SODIUM (NA)
TOT ACID (PH7)
TOT ACID (PH7)
TOT ACID (PH7)
TOTAL ORGANIC
CARBON
TOTAL ORGANIC
CARBON
TOTAL ORGANIC
CARBON
TOTAL ORGANIC
CARBON
TOTAI ORGANIC
CARBON
TOTAL ORGANIC
CARBON
TOTAL ORGANIC
CARBON
TOTAL ORGANIC
CARBON
TOTAL ORGANIC
CARBON

PAGE 93

WSRC-RP-92-996

\begin{tabular}{|c|c|c|c|}
\hline Value & & Units & $\begin{array}{c}\# \\
\text { Analyses }\end{array}$ \\
\hline 2158 & & $M G / L$ & \\
\hline Value & & Units & \\
\hline 2152 & & MG / L & \\
\hline 2147 & & $M G / L$ & \\
\hline 2165 & & $M G / L$ & \\
\hline 2163 & & $M G / L$ & \\
\hline 2157 & & $M G / T$ & \\
\hline 10 & $(A-$ & MG / L & \\
\hline 9 & $(A-2)$ & MG / L & \\
\hline 10 & $(A-3)$ & $\mathrm{MG} / \mathrm{L}$ & \\
\hline 10 & $(B-1)$ & $\mathrm{MG} / \mathrm{L}$ & \\
\hline 13 & $(B-2)$ & $\mathrm{MG} / \mathrm{L}$ & \\
\hline 28 & $(B-3)$ & MG / L & \\
\hline 11 & $(C-1)$ & $M G / L$ & \\
\hline 10 & $(C-2)$ & $M G / I$ & \\
\hline$<1$ & (C- & $M G / L$ & \\
\hline 5875 & & PPM & \\
\hline 7376 & & PPM & \\
\hline (A) & .18 & MOLE/L & \\
\hline (B) & .18 & MOLE/L & \\
\hline (C) & .19 & MOLE/L & \\
\hline$A-1=$ & $=9744$ & PPM & \\
\hline$A-2=$ & $=9606$ & PPM & \\
\hline$A-3=$ & $=9814$ & PPM & \\
\hline$B-1=$ & $=9809$ & PPM & \\
\hline$B-2=$ & $=9763$ & PPM & \\
\hline$B-3$ & 9660 & PPM & \\
\hline$c-1=$ & $=9849$ & PPM & \\
\hline$C-2$ & $=9757$ & PPM & \\
\hline$C-3=$ & $=9700$ & PPM & \\
\hline
\end{tabular}


DATE

FILMED

$4 / 20 / 93$ 